UNIVERSIDADE DE SÃO PAULO

ESCOLA DE COMUNICAÇÕES E ARTES

FRANCISCO TUPY GOMES CORRÊA

(FRANCISCO TUPY)

VIDEOGAME COMO LINGUAGEM AUDIOVISUAL:

COMPREENSÃO E APLICAÇÃO

EM UM ESTUDO DE CASO -

SUPER STREET FIGHTER IV

SÃO PAULO

2013 


\author{
UNIVERSIDADE DE SÃO PAULO \\ ESCOLA DE COMUNICAÇÕES E ARTES
}

\author{
FRANCISCO TUPY GOMES CORRÊA \\ (FRANCISCO TUPY)
}

\title{
VIDEOGAME COMO LINGUAGEM AUDIOVISUAL: \\ COMPREENSÃO E APLICAÇÃO \\ EM UM ESTUDO DE CASO - \\ SUPER STREET FIGHTER IV
}

\begin{abstract}
Dissertação apresentada ao Programa de Pósgraduação em Meios e Processos Audiovisuais da Escola de Comunicações e Artes da Universidade de São Paulo, como exigência parcial para obtenção do título de Mestre em Meios e Processos Audiovisuais, sob a orientação do Prof. Dr. Gilson Schwartz.
\end{abstract}

SÃO PAULO

2013 
Autorizo a reprodução e divulgação total ou parcial deste trabalho, por qualquer meio convencional ou eletrônico, para fins de estudo e pesquisa desde que citada a fonte.

\section{Catalogação na Publicação \\ Serviço de Biblioteca e Documentação \\ Escola de Comunicações e Artes da Universidade de São Paulo Dados fornecidos pelo(a) autor(a)}

Correa, Francisco Tupy Gomes

Videogame como linguagem audiovisual : Compreensão e aplicação em um estudo de caso - Super Street Fighter IV /

Francisco Tupy Gomes Correa. -- São Paulo: F. G. Correa, 2013.

121 p. : il.

Dissertação (Mestrado) - Programa de Pós-Graduação em Meios e Processos Audiovisuais - Escola de Comunicações e Artes / Universidade de São Paulo.

Orientador: Gilson Schwartz

1. Linguagem Audiovisual 2. Cinema 3. Videogame 4. Metáporo 5. Street Fighter I. Schwartz, Gilson II. Título. 
BANCA EXAMINADORA

Prof(a). Dr(a). Instituição:

Assinatura:

Prof(a). Dr(a). Instituição:

Assinatura:

$\operatorname{Prof}(a) . \operatorname{Dr}(a)$. Instituição:

Assinatura: 
Dedico este trabalho às contribuições que fomentaram a minha matriz, à essência que possuo e que hoje reflete aquilo que sou.

À minha elegante Vó Neta, a quem devo a habilidade de recortar e costurar com bom gosto as coisas que a vida me trouxe. Ao meu polimata Vô Chico, a quem devo o gosto pelas estradas e jornadas, pela inventividade de manipular imagens e pelo gosto dos esportes de combate.

Ao meu cinéfilo Vô Luis, a quem devo o gosto dos quadrinhos e do jogo de xadrez. À minha "suigeneris" Vó Tiana, a quem devo o bom humor e exemplo de superação, eterna companhia para assistir novela, Charles Bronson, Van Damme e o Pairulito. 
Agradeço a todos aqueles que contribuíram com este trabalho. Se fosse citar todos os nomes, faltariam páginas para nomear aqueles que estiveram ao meu lado e o quanto contribuíram para a realização desta pesquisa.

MUITO OBRIGADO!
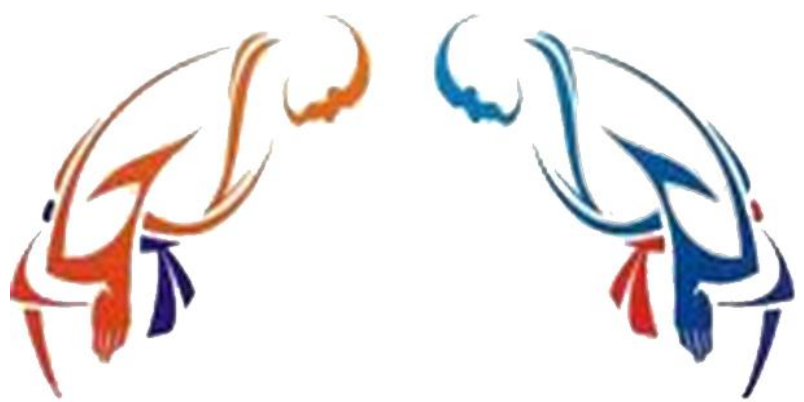

Agradeço especialmente ao Prof. Dr. Gilson Schwartz, que confiou em mim e deu oportunidade para o meu desenvolvimento. Tantos eventos, projetos, viagens, trocadilhos que nem dá para contar. Resumindo: \#epicwin!

Estendo esse agradecimento aos professores das disciplinas cursadas, pois a pesquisa foi ganhando sentido em cada aula, em cada conversa no corredor, em cada dúvida convertida em inspiração: Profa. Dra. Arlete Petry, Prof. Dr. Ismar Soares, Profa. Dra. Marilia Franco (x2) e Prof. Dr. Sérgio Bairon.

Sabe para quem também devo um obrigado?

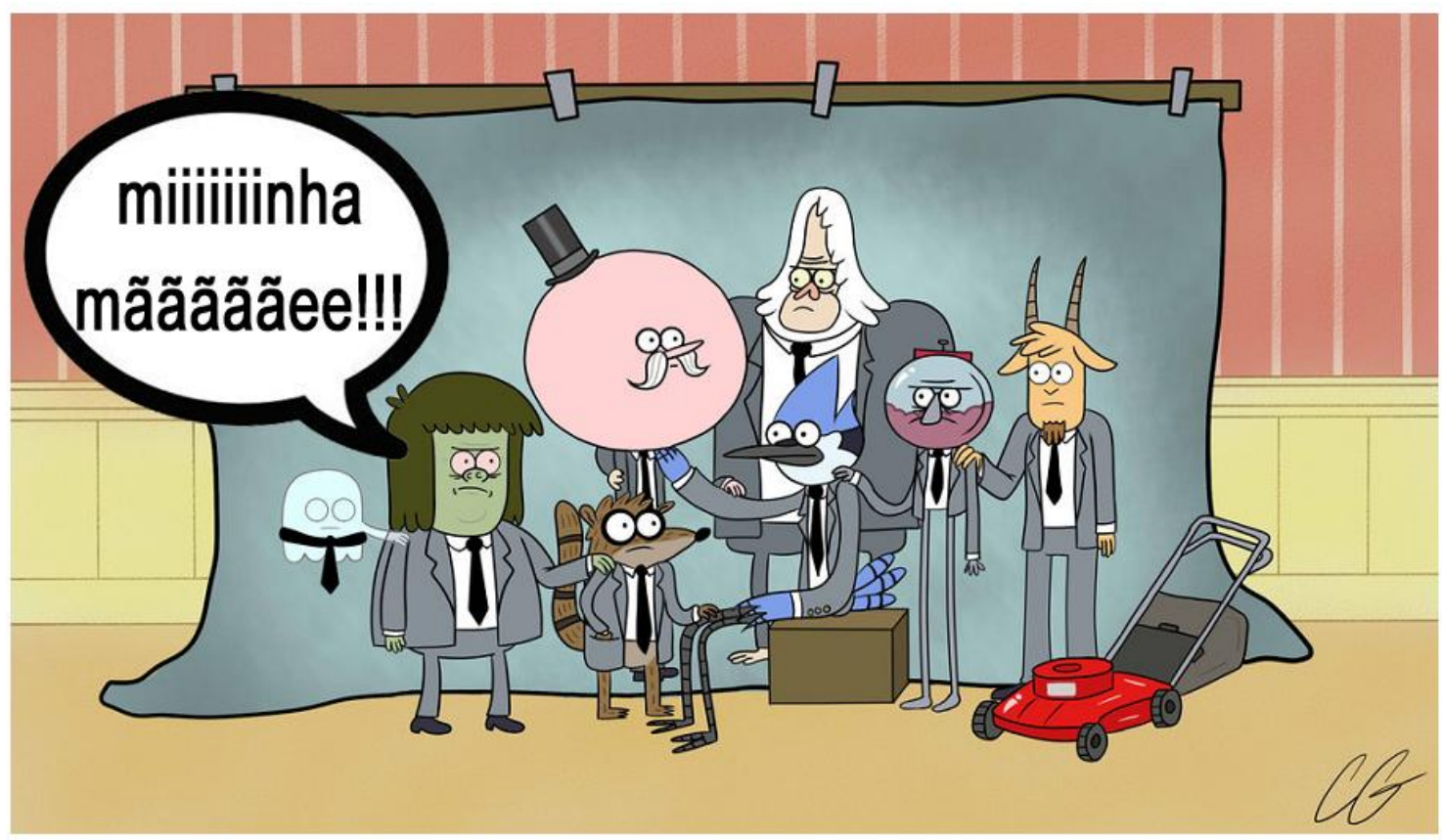

Arte fandom do artista CG "modificado pelo autor", baseado na obra de J. G. Quintel "Apenas um show" 


\section{Resumo}

A relação entre os aspectos fílmicos e lúdicos dos jogos vão muito além da palavra videogame. Essa terminologia frente à humanidade é muito recente, apenas com algumas dezenas de anos, porém, trata-se de algo que converge em símbolos, técnicas e práticas, revestindo tais itens contemporâneos e impactando a sociedade significativamente. Logo, configura-se como um objeto de estudo capaz de promover reflexões diversas. No caso desta pesquisa, consideramos que nessa expressão do ato de jogar existe muito de game e pouco de vídeo. As abordagens focando as narrativas e as mecânicas muitas vezes deixam uma lacuna referente aos processos audiovisuais. Em função desta observação, foi realizado um estudo de cunho hipotético-dedutivo e metapórico preconizando uma visão integradora de três métodos distintos: a Ludologia, a Narratologia e a Linguagem Audiovisual. A motivação do título escolhido para o estudo de caso, Super Street Fighter IV, ocorreu por ser um jogo popular, dentro de um gênero típico de jogabilidade, que há mais de duas décadas se reinventa para agradar os fãs. Além disso, dialoga diretamente com temas culturais (costumes asiáticos e artes marciais) e temas cinematográficos (filmes de luta e o ícone representado por Bruce Lee). O estudo focou os resultados visando contribuir para uma compreensão do videogame, de modo que a pesquisa realizada pudesse trazer parâmetros tanto para aprofundar elementos presentes em sua linguagem quanto para o desenvolvimento de questões de ligadas à sua realização.

Palavras-chave: linguagem audiovisual; cinema; videogame; metáporo; Street Fighter. 


\begin{abstract}
The relation between cinematographic and ludic aspects of games go well beyond the Word videogame. This term is very recent in human history, having appeared only a few decades ago. However, it is something the converges in symbols, techniques and practices, labelling these contemporary items and significantly impacting society. For this reason, it presents itself as a study subject that is capable of promoting diverse reflections and discussions. In this research, we considered that in this expression of the act of playing there is much more game than video. Approaches that focus on narratives and mechanics often don't refer to audiovisual processes. Based on this observation, we devised a hypothetic-deductive, and metaphoric study that considers three distinct methods: Ludology, Narratology, and Audiovisual Language. The motivation behind the chosen subject of study, Super Street Fighter IV, comes form it being a popular game, from a genre that is mainly based on playability, with more than two decades of reinvention in order to please fans. Besides, it directly dialogs with cultural (Asiatic costumes and martial arts) and cinematographic themes (fight movies and the popular icon Bruce Lee). The study focused the results in order to contribute to a comprehension of video-games, in a way that the research could bring parameters both to deepen elements that help better understanding this language, and to aid the development of questions concerned to realization.
\end{abstract}

Keywords: audio-visual language; cinema; videogame; metapore; Street Fighter. 


\section{Lista de Figuras}

Figura 1 - Esquema de conexão entre autores e temas ...................................................... 22

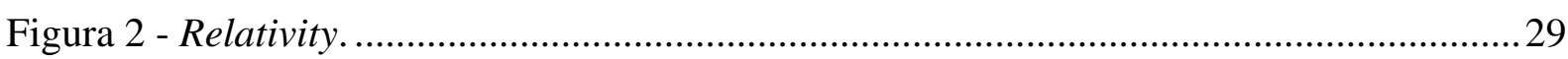

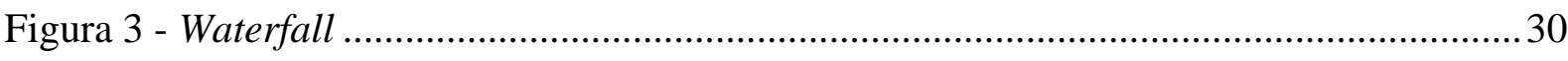

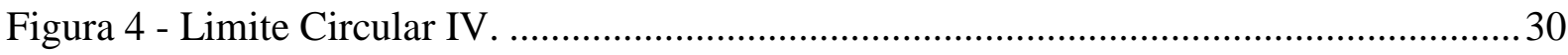

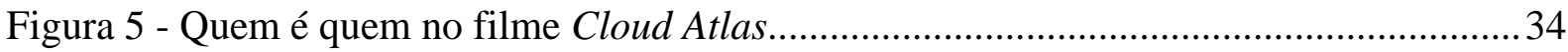

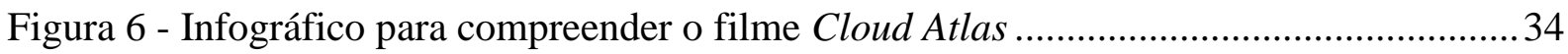

Figura 7 - Axis Mundi na interface do Jogador e do Jogo .................................................. 35

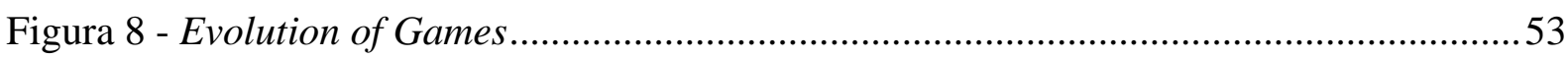

Figura 9 - A Brief History of Social Games 3100BC - 2010AD .............................................56

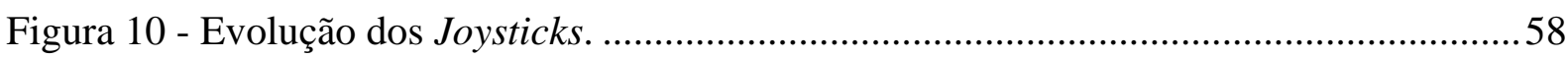

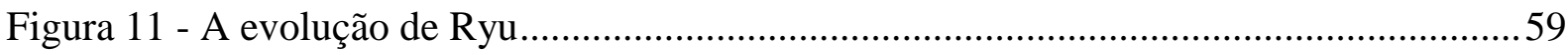

Figura 12 - Ryu, Super Street Fighter IV ...........................................59

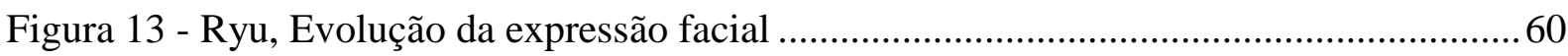

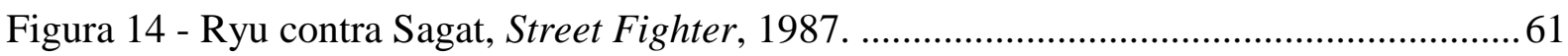

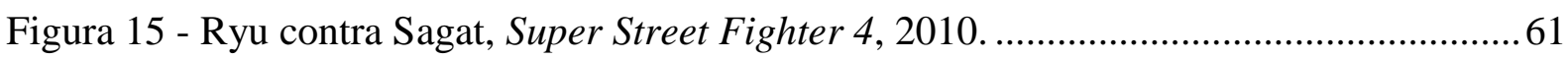

Figura 16 - Releitura da imagem Evolution of Games considerando os Videogames............. 62

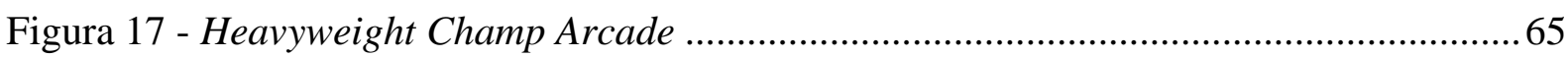

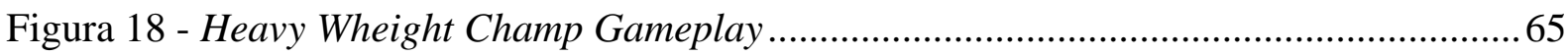

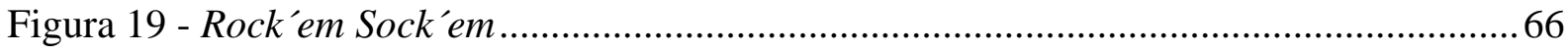

Figura 20 - Rock'em Sock'em com personagens Street Fighter .............................................67

Figura 21 - Ilustração irônica sobre Rock'em Sock'em e Street Fighter ................................. 68

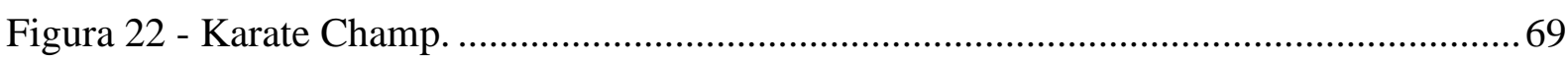

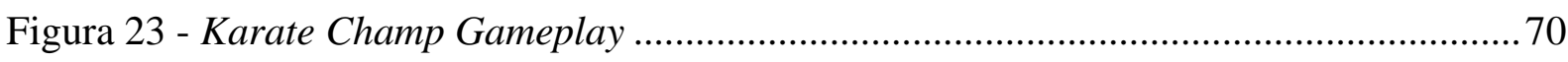

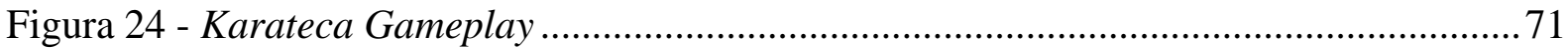

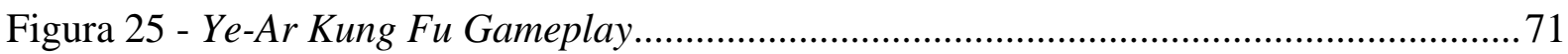

Figura 26 - Percentages of genre and plataform releases since 1975 ................................... 72

Figura 27 - Video Game Archetypes: Bruce Lee Homages. ...................................................... 73

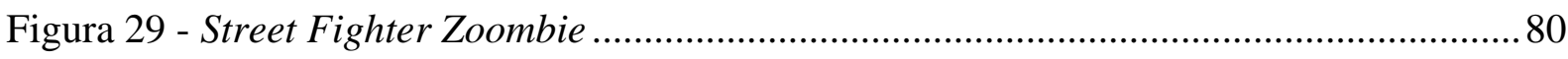

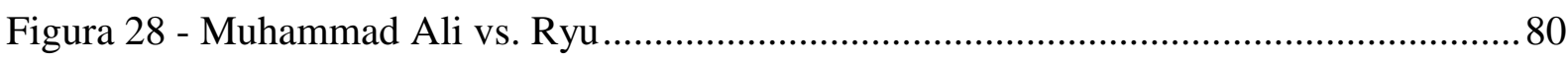




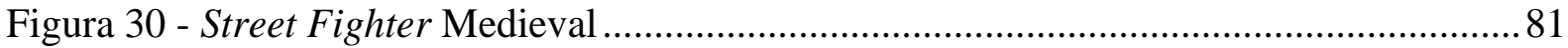

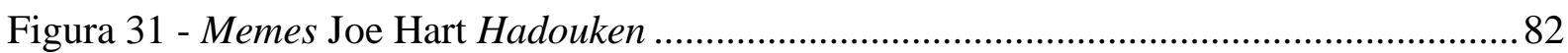

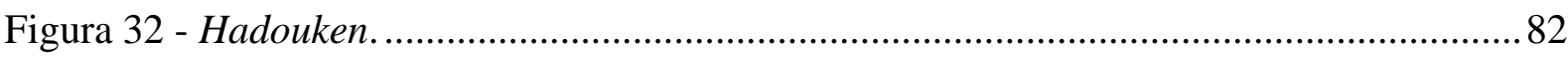

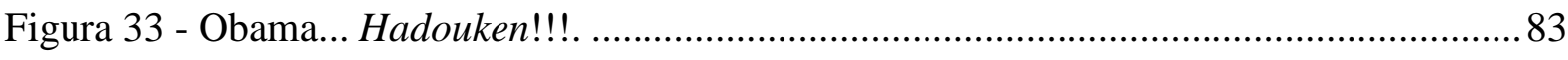

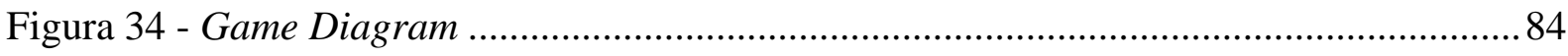

Figura 35 - Narrativa Embutida (CHATMAN, 1976) e Emergente (DUBIELA;

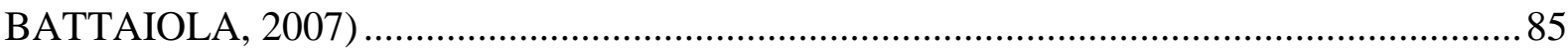

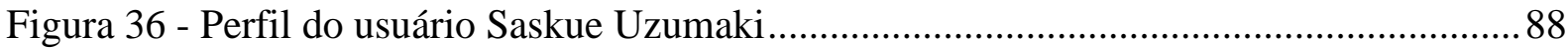

Figura 37 - Timeline de comentários do vídeo utilizado nesta pesquisa................................90

Figura 38 - Mosaico de vídeos postados pelo usuário ...........................................................91

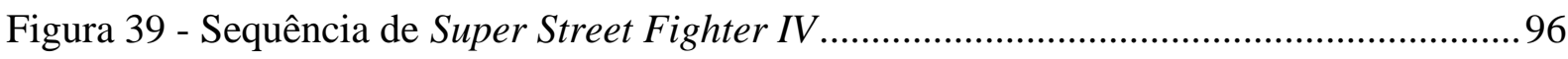

Figura 40 - Super Street Fighter IV - Relationship Chart......................................................99

Figura 41 - Distribuição de tempo total dos Planos do Jogo .................................................... 103

Figura 42 - Distribuição dos planos em função do tempo..................................................... 103

Figura 43 - Intersecção entre as três linhas de análise.......................................................... 112 


\section{Lista de Tabelas}

Tabela 1 - Compilação Prévia de definições de jogos ............................................................. 45

Tabela 2 - Relação entre o jogador e o jogo de acordo com as definições prévias .................. 46

Tabela 3 - Ranking de Franquias de Jogos de Luta 1981-2013 ............................................. 77

Tabela 4 - Jogos da Franquia Street Figther 1987-2013 _...................................................... 78

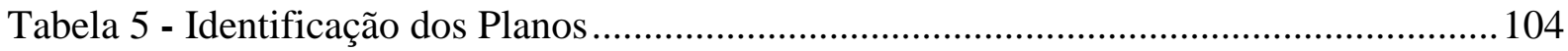




\section{Sumário}

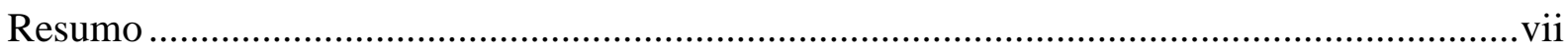

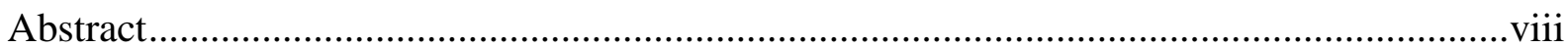

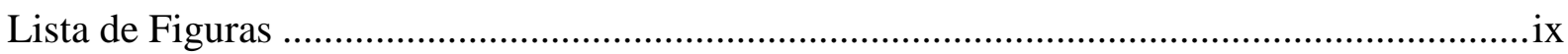

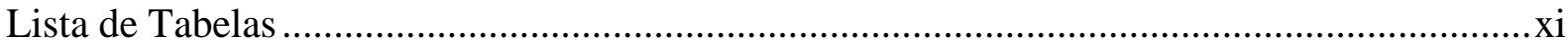

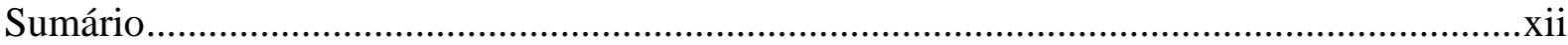

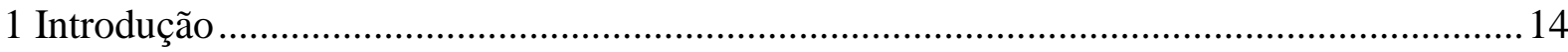

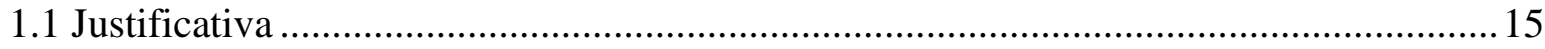

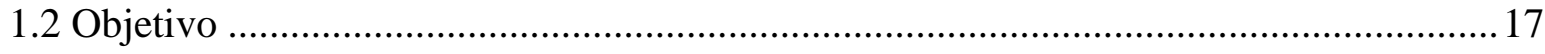

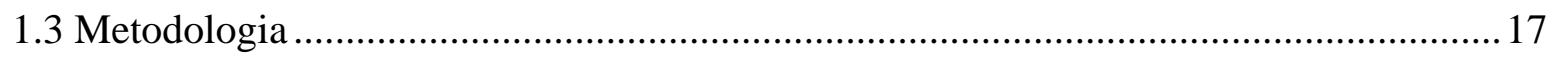

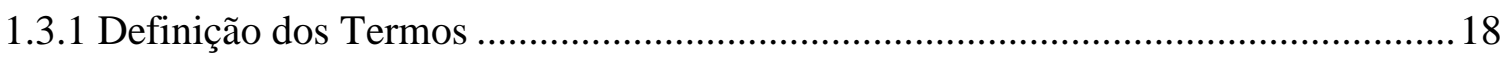

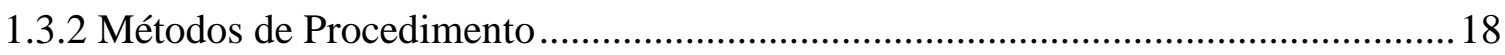

2 Possíveis abordagens do audiovisual no ato de jogar..................................................... 21

2.1 A matriz audiovisual nos games e na Teoria dos Videogames................................... 21

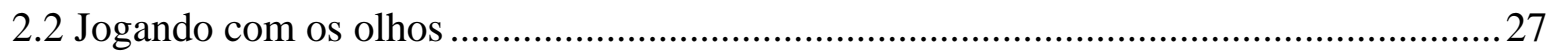

2.3 Documentário como forma de registro e de pesquisa aplicado aos videogames ............36

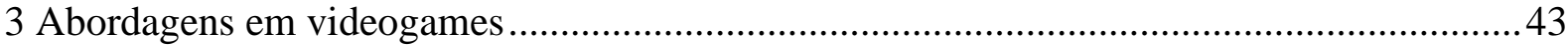

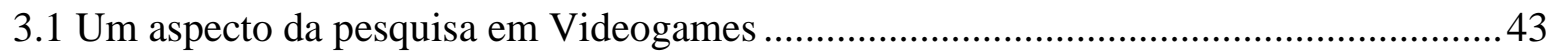

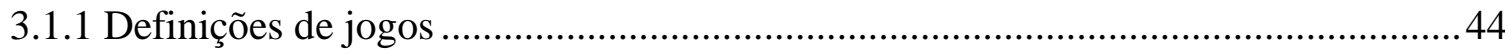

3.2 A evolução dos jogos no contexto audiovisual...........................................................51

3.3 A temática das artes marciais no cinema e nos videogames......................................62

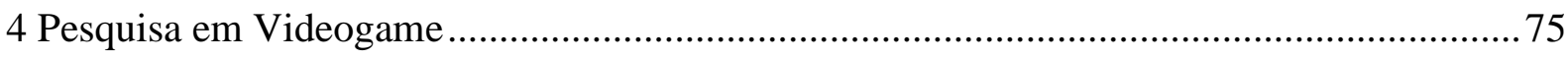

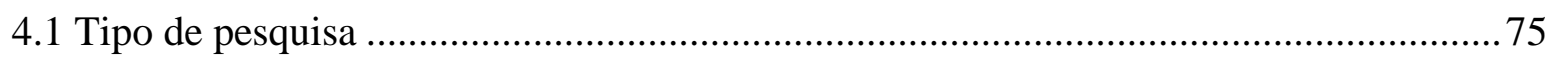

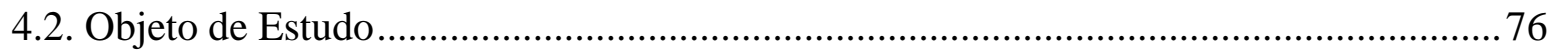

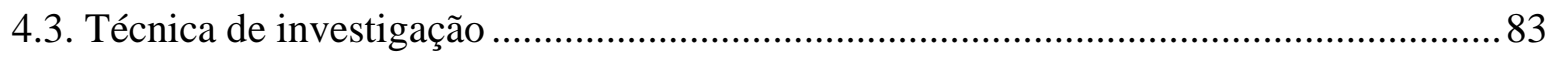




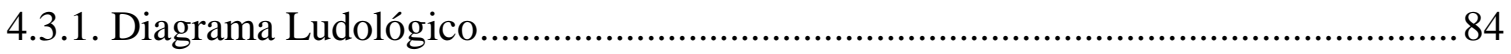

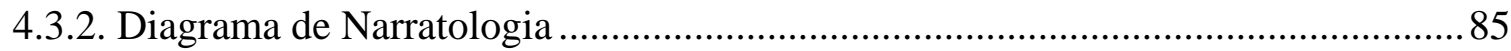

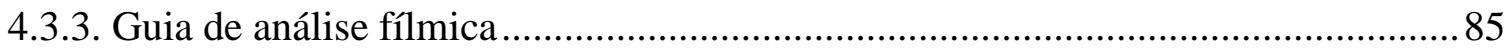

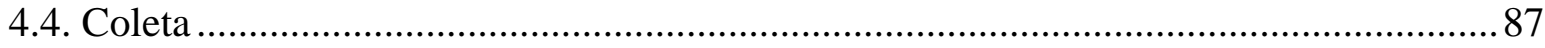

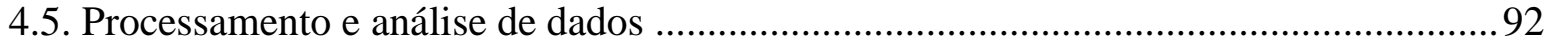

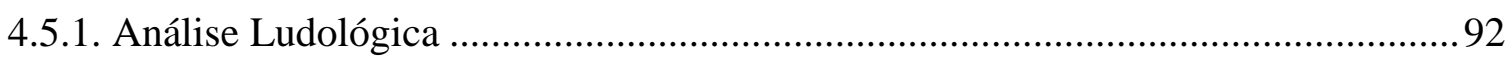

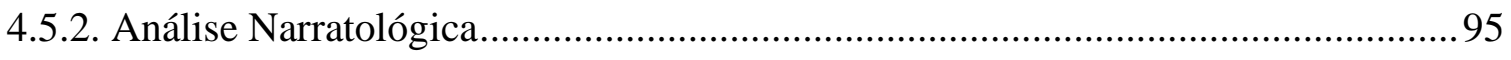

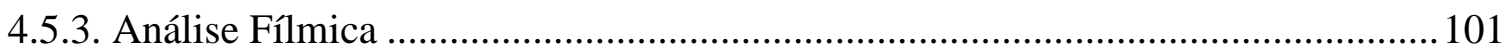

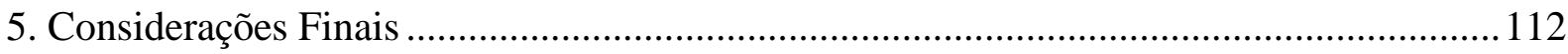

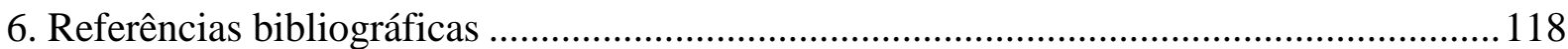




\section{Introdução}

O videogame é composto pelas matrizes, a do vídeo, com a cultura audiovisual, e a do game, com seus aspectos lúdicos. Esta pesquisa analisou o game design embasada na:

- ludologia (com foco majoritariamente na mecânica do jogo e na interação com jogadores);

- na narratologia (relacionada ao aspecto audiovisual enfocando o lado histórico e o de roteirização);

- na análise fílmica (ponto de equilíbrio entre a história que pode ser desenvolvida mediante a perícia do usuário e as questões especificamente fílmicas utilizadas neste conceito - como enquadramento, feedbacks visuais, etc.).

A necessidade de aproximação das três variáveis citadas ampliou a capacidade de compreensão da questão fílmica nos jogos, criando possibilidades de aplicação em pesquisas, de realização de jogos e para fins didáticos. As questões ligadas ao conteúdo audiovisual na ontologia do game design são muitas vezes alcançadas em situações de tentativa e erro, por isso foi feito um estudo do Super Street Fighter 4, que possibilitou analisar essas questões de forma mais detalhada. Trata-se de um estilo de jogo muito parecido com filmes de ação, principalmente os de lutas e de artes marciais, e faz parte de uma das maiores franquias da história dos videogames, tendo atingido mais de 30 milhões de cópias vendidas no mundo e arrecadando mais de 1 bilhão de dólares com a marca. Completou recentemente 25 anos de existência e conta com um vasto universo de elementos presentes na cultura popular (personagens, trilha sonora, onomatopeias, símbolos, etc.) ${ }^{1}$. Neste jogo, pode ser identificada uma série de fatores que pode promover junto ao jogador o máximo de experiência sinestésica de fruição de caráter audiovisual e de jogabilidade, contextualizada com a cultura das redes sociais digitais.

O objeto de estudo foi submetido a uma análise de observação e as imagens foram pesquisadas em redes sociais digitais de publicação de vídeo, como o Youtube. Com as imagens, foram aplicados instrumentos de análise fílmica para a função vídeo; ludológica e narratológica para o game.

\footnotetext{
${ }^{1}$ Disponível em: <http://en.wikipedia.org/w/index.php?title=List_of_bestselling_video_game_franchises\&oldid=528886569>. Acesso em: 8 de setembro de 2011 .
} 
Com os dados levantados na análise proposta, foi feita uma descrição apontando onde estas áreas se combinam, se opõem ou se complementam. Mediante esta comparação foram promovidos parâmetros integrados no trinômio baseado na mecânica de interação, na narrativa embutida e emergente e nos elementos audiovisuais.

\subsection{Justificativa}

Com menos de 40 anos no mercado, os jogos de videogame têm provocado um grande impacto na cultura da humanidade. Só no aspecto econômico, atualmente os lucros desta indústria ultrapassam os do cinema e os da música, movimentando um mercado específico como agente propulsor de grande quantidade de empregos. Com isso, tem influenciado, além da economia, aspectos comportamentais, gerando fenômenos sociais que necessitam ser estudados, compreendidos e sistematizados, para que a própria sociedade se beneficie destas informações desmistificando e decodificando os embates que surjam a respeito da interpretação e atribuição dos jogos baseados pelo senso comum e pelo sensacionalismo de mídia descompromissada.

As atividades de pesquisa ligadas ao universo dos videogames poderão contribuir para a construção de caminhos que gerem mais oportunidades profissionais, perante fronteiras estabelecidas pela falta de linhas de análise que ajudem numa melhor compreensão deste segmento. $\mathrm{O}$ que vemos são pesquisas que versam sobre o tema videogame que utilizam aspectos deste universo, porém, dentro de programas como: Sociologia, Ensino, Estética, Semiótica, Inteligência Artificial, Engenharia, Artes, entre outros. Portanto, a realização de uma pesquisa com essa temática servirá para aumentar a compreensão do fenômeno gerado pelos Videogames na sociedade e para auxiliar na edificação desta nova área de conhecimento, contribuindo com questões teóricas facilitando a análise do segmento, a criação de jogos e até para o ensino, direta ou indiretamente.

Se examinarmos bem, podemos perceber que o campo que separa os jogos do audiovisual não tem fronteiras muito claras. Hoje, profissionais de diversas áreas estão se aproximando dos videogames. Esta pesquisa segue uma tendência não apenas dentro de um contexto acadêmico crescente, mas também na esfera profissional em relação à possibilidade 
de atuação e da valorização das técnicas audiovisuais voltadas para a melhoria da qualidade do que está sendo produzido.

Além dos aspectos abordados, outras questões que tangenciam os resultados desta pesquisa reforçam a proposta de sua execução. É sabido que títulos famosos de videogames exercem grande fascínio junto ao público de um modo geral, inclusive em crianças e adolescentes. Embora não exista no jogo escolhido, bem como em muitos outros títulos, a intenção de ensino, à medida que utilizamos questões para a compreensão da relação audiovisual nos videogames, parte daquilo que for auferido nas pesquisas pode ser aplicado em sala de aula.

$\mathrm{O}$ videogame em relação às suas teorias de estudo não se vale do conceito vídeo, uma vez que a palavra vídeo é relegada para enfatizar a questão game, ou seja, a mecânica da criação do jogo. Ao aproximar questões da análise fílmica ou mesmo da percepção da imagem a itens ligados à ludologia e à narratologia, pode haver uma ampliação de possibilidades de compreensão sobre estes elementos presentes nos jogos.

A conciliação dos pressupostos da avaliação ludológica com a linguagem audiovisual possibilitará gerar protocolos para game designers e para realizadores de vídeos que, mesmo não fazendo nada interativo, possam valer-se de símbolos dos games.

Por fim, a abordagem entre os games e a questão audiovisual permite desenvolver conteúdo ligado à questão de ensino para os meios, traçando relações entre interatividade e mudança na consciência do usuário, uma vez que, no senso comum, existe ainda uma série de preconceitos em relação ao videogame, que é culpado por gerar violência e por ser uma atividade que atrapalha os estudos.

Seja como processo de desenvolvimento, seja como objeto aplicado como instrumento, devido à profundidade de teores utilizados na busca e geração de sentido, os games podem ser utilizados, com a devida compreensão, para promover conteúdos disciplinares dos Parâmetros Curriculares Nacionais (PCNs) estabelecido pelo MEC, bem como para desenvolver curiosidade em questões culturais tecnológicas e de conteúdo (Filosofia, História, Artes, etc.) além de conscientizar as cadeias de produção e as etapas de criação que envolvem o jogo, formando assim usuários ativos e conscientes dos processos envolvidos e dessa cadeia de produção. 


\subsection{Objetivo}

O principal objetivo desta pesquisa foi realizar um estudo sobre os videogames perante a linha de análise do audiovisual. A partir das análises feitas sobre o objeto embasado na bibliografia proposta, buscamos responder a conjectura motriz da análise em questão: o hiato existente entre a teoria com reflexo na questão prática entre os videogames e a linguagem audiovisual. Mediante os cânones da linha de pesquisa, aprofundamos conceitos e geramos resultantes como:

- aumento do grau de compreensão sobre o videogame;

- otimização das formas de produção do ponto de vista audiovisual;

- aplicabilidades associadas à transmissão de conhecimento;

- identificação dos elementos audiovisuais no jogo Super Street Fighter 4;

- comparação de convergências e divergências entre os elementos audiovisuais com os elementos de jogabilidade e de narratologia;

- apresentação de parâmetros de utilização da interface, tanto da linguagem audiovisual quanto de jogabilidade (de modo que possa ser usado igualmente como ferramenta de análise e para a criação de jogos);

- certificação de pertinência da condição de usabilidade de documentários (que embasou o estudo, mediante a escolha de documentários sobre temáticas correlatas ao tema, como, por exemplo: artes marciais, filmes de artes marciais, jogadores de Street Fighter, entre outros).

\subsection{Metodologia}

O método de análise segue o padrão hipotético-dedutivo, pois esta pesquisa visou suprir uma lacuna identificada perante questões que tangenciam a aplicabilidade da teoria à realidade. O pressuposto teórico-metodológico preconizou a análise frente ao fenômeno apontado (POPPER, 1993). O dinamismo estético, presente no viés da natureza audiovisual da obra, permitiu uma abordagem focada na "razão durante" da perspectiva metapórica (MARCONDES, 2010).

A revisão bibliográfica baseou-se majoritariamente em dois eixos: o dos Videogames e o da Linguagem Audiovisual. 


\subsubsection{Definição dos Termos}

- Jogo: utilizado perante a polissemia ontológica, associado às questões lúdicas/competitivas, de forma digital ou antológica, englobando qualquer um dos outros termos utilizados pela linguagem. Faz referência a jogos analógicos (tabuleiros, cartas, dados, go, xadrez) e digitais (videogames).

- Videogame: plataformas midiáticas que permitem o ato de jogar, associadas a aparelhos que possuem tela, com suporte audiovisual perante a interatividade do usuário. Foram consideradas neste termo formas ubíquas e pervasivas, jogos conectados por redes ou múltiplas plataformas.

- Plataformas: sistemas operacionais que rodam os jogos. Podem ser consoles que se conectam à televisão (Dactar, Super Nintendo, Mega Drive, Playstation 3, Xbox 360, Wii, etc.), podem ser dispositivos móveis unicamente com essa finalidade (Game Gear, Game Boy, etc.), jogados diretamente nos aparelhos (PCs instaláveis ou no browser, celulares, tablets) e as Smart TVs, conectadas à internet e com processadores e memória que podem jogar sem console.

- Game: termo genérico que engloba as atividades realizadas dentro dos videogames.

- Título: termo específico voltado a um jogo (neste caso, o game). Assim como em filmes, o título é uma unidade específica executada por uma equipe;

- Seção de Jogo: partida, é quando um ou mais usuários jogam, considera-se cada seção como um evento único.

\subsubsection{Métodos de Procedimento}

A orientação técnica da pesquisa seguiu o padrão estruturalista, ou seja, sistêmico, uma vez que a análise do objeto principal foi feita mediante matrizes de classificação, estruturação do fenômeno apresentado e sua relação com a realidade. Tivemos três matrizes distintas, uma ludológica (JUUL, 2003), uma narratológica (CHATMAN, 1978) e uma fílmica, compilada de Vanoye e Goliot-Lété (1994).

Além da pesquisa de gabinete, referente ao levantamento bibliográfico, foi feita uma observação de seções de partida do personagem, com o título Super Street Fighter 4, disponibilizadas no Youtube, onde foi possível visualizar jogos de usuários específicos, 
comentários da comunidade na linha do tempo, tags e caixas dentro da própria imagem, expressando ideias de mérito, falhas e até mesmo ironias. A técnica escolhida está inserida nas seguintes especificações, conforme descrito por Lakatos e Marconi (1992):

- documentação indireta: em relação à pesquisa bibliográfica;

- observação direta intensiva: em relação ao objeto de estudo no tocante à utilização dos sentidos (visão, audição e interação) para examinar os fenômenos pretendidos de forma sistêmica, não participante, individual e na vida real, através da seção de jogo captada por

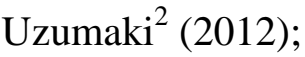

- observação direta e extensiva: em relação à coleta de respostas nos comentários dos usuários do Youtube com foco na medida de opinião e atitudes, análise de conteúdo e histórico de vida; - observação direta e extensiva: em relação a documentários disponibilizados aos usuários do Youtube com temática correlata à pesquisa, tais como: The Curious Creative (2011); Chubby Boys Films (2012); Cofino (2012); Columbia Tristar Pictures (2012); National Geographic (2011). Outros vídeos foram considerados no decorrer da pesquisa.

Os instrumentos de pesquisa utilizados foram:

- Matriz ludológica de Jesper Juul (2003) que teve por objetivo identificar os seis itens que compõem o jogo;

- Matriz narratológica, dividida na parte de Embutida (CHATMAN, 1978) e Emergente (DUBIELA; BATTAIOLA, 2007);

- Matriz fílmica, compilada da obra de Vanoye e Goliot-Lété (1994).

Após a devida observação e preenchimento das matrizes, foi feita a comprovação das hipóteses em função do cumprimento ou não dos objetivos pretendidos. Como seguimos a lógica hipotético-dedutiva popperiana, estruturamos a cadeia de fases da comprovação para saber se a pesquisa atingiu satisfatoriamente aquilo que fora proposto desenvolver:

Problema $\rightarrow$ Hipótese (neste caso, devido ao nível de pesquisa, utilizamos o termo conjectura) $\rightarrow$ Dedução de Consequências observadas $\rightarrow$ Tentativa de Falseamento $\rightarrow$ Corroboração

\footnotetext{
${ }^{2}$ UZUMAKI, S. Super Street Fighter 4 - Ryu Playthrough. Disponível em:

<http://www.youtube.com/watch?v=VxDNMXq1Y5I>. Acesso em 16 de agosto de 2012.
} 
Este modelo pressupõe uma estruturação para padrões associados às questões ligadas mais às ciências exatas. Ater-se a ele como base trouxe o lastro de cientificismo para que as atividades de pesquisa não corressem o risco de cair em elucubrações, já que passos apontados como busca por uma problemática e tentativa de falsear os dados levantados são uma maneira de colocar à prova aquilo que foi estudado, evitando escapar do escopo de pesquisa. Contudo, a questão do falseamento, que promove uma relação de autoprova daquilo que foi auferido, reflete modelos e até mesmo equações (o que, devido à natureza desta pesquisa, é algo que pode provocar relação de conflito). Pensando desta maneira, a ideia foi contrapor o método com o quase-método, o metáporo (MARCONDES, 2010).

O objeto de pesquisa e sua destinação estão associados diretamente com questões menos exatas e mais estéticas que envolvem a fruição dos sentidos, por isso utilizamos a lógica hipotético-dedutiva e a lógica metapórica. De um lado, tivemos um rigor analítico científico e, de outro, uma abordagem que permitiu certa liberdade de análise e manipulação do objeto de pesquisa, indo diretamente ao que fora proposto por Gadamer (1997).

A postura metapórica é divida em três fases (uma orientação referente à conduta de pesquisa, ao objeto e à apresentação de resultados), diferentemente das ciências positivas. $\mathrm{O}$ Metáporo não mitiga, analisa ou sistematiza, mas busca captar a análise como o próprio objeto, focando-se em questões subjetivas como a intuição sensível. A legitimidade do resultado buscou ir além das investigações empíricas promovidas pelo caráter de observação que busca condições de possibilidade nômade, em contínuo movimento, capaz de produzir o novo. 


\section{Possíveis abordagens do audiovisual no ato de jogar}

\subsection{A matriz audiovisual nos games e na Teoria dos Videogames}

A linguagem audiovisual é um preciso construto que permite aos sentidos sensórios remotos dos espectadores serem embebidos naquilo que olhos e ouvidos captam e, posteriormente, tragam para si a realidade mostrada na tela.

A experiência foi conduzida por uma série de elementos (habilidades, profissionais e equipamentos específicos) que, quando combinados, permitem a contemplação dos seguintes processos: enquadramento, iluminação, movimento da câmera, elementos visuais (maquiagem, cenário, figurinos e expressão dos atores), elementos de áudio (três ambientes sonoros - falas, ruídos e música) e, por fim, a montagem ou edição.

(...) podemos dizer que toda a organização expressiva da linguagem audiovisual privilegia o contato com a sensibilidade do espectador (...) Do ponto de vista pedagógico a compreensão deste princípio foi a chave de todo o trabalho com o audiovisual na sala de aula e para estabelecer essa relação sensível com o espectador, para a linguagem audiovisual, utilizamos elementos que excederam os aparelhos perceptivos do ser humano visão, audição, olfato, paladar, tato - de modo a conduzi-lo por uma "viagem sensorial virtual" que carrega uma história a ser contada. (NCE-USP, s.d.)

A partir da relação entre o que é veiculado na tela, interface e mente, existe uma base para compreender os videogames e refinar parâmetros para sua utilização, voltada à criação de conteúdos (principalmente para transmissão de mensagens de conscientização) ou mesmo à aplicação de títulos para fins de aprendizagem.

Os videogames, mídia emergente, enquadrando-se na ótica da Comunicação Social, estão equiparados a outros tipos de mídias, tanto com vantagens quanto com desvantagens. Por isso, são necessários estudos que possibilitem dirimir tais distorções e ajudem em sua compreensão, para um melhor aproveitamento de seu potencial comunicativo. De acordo com Braga e Calazans (2001), trata-se de um processo que pode ser considerado dialógico, direcionado e de retorno direto, uma vez que todos seus atos e ações recebem "feedbacks", ou seja, consequências imediatas devido às estruturas imagéticas que o compõe com ícones de sucesso e derrota. Além disso, estando os jogos cada vez mais integrados frente às redes sociais, tornam-se eixo de comunicação não apenas direta, mas de valores, símbolos e atos divulgados entre os grupos que os acessam. O caráter interativo preconizado por tal tipo de plataforma desperta o interesse, assumindo um papel de diversão e entretenimento, o que gera certo deslumbramento, afetando as vantagens que tal suporte de comunicação pode trazer. Da 
mesma forma que o homem é comunicativo por natureza, é também lúdico, por isso, associamos o ato de jogar não apenas a um momento de lazer, mas a algo presente nos demais seguimentos da vida.

(...) a importância dos novos meios não deriva apenas dos oferecimentos imediatos que nos fazem (imagem, som, registro, reprodutibilidade técnica, aceleração, simulação, virtualização); mas também de suas características modificadoras das objetivações possíveis na Comunicação como, inclusividade e penetrabilidade. Estas ações modificadoras e as mudanças de percepção levam a outras experiências como as tentativas de ensaio-e-erro de construção do social por parte dos produtores e dos usuários. (BRAGA; CALAZANS, 2001, p. 32)

A necessidade de expressão e de comunicação anda junto com a manifestação de uma narrativa simbólica, gerando um complemento ao sistema material e recebendo um revestimento de expressão estética individual e coletiva conforme preconizam as redes sociais digitais. Isso permite a contextualização dos reflexos da sociedade em função dos objetivos comunicacionais, portanto, buscamos contemplar uma análise centrada no trinômio: o jogador, a tela e a interface (Figura 1).

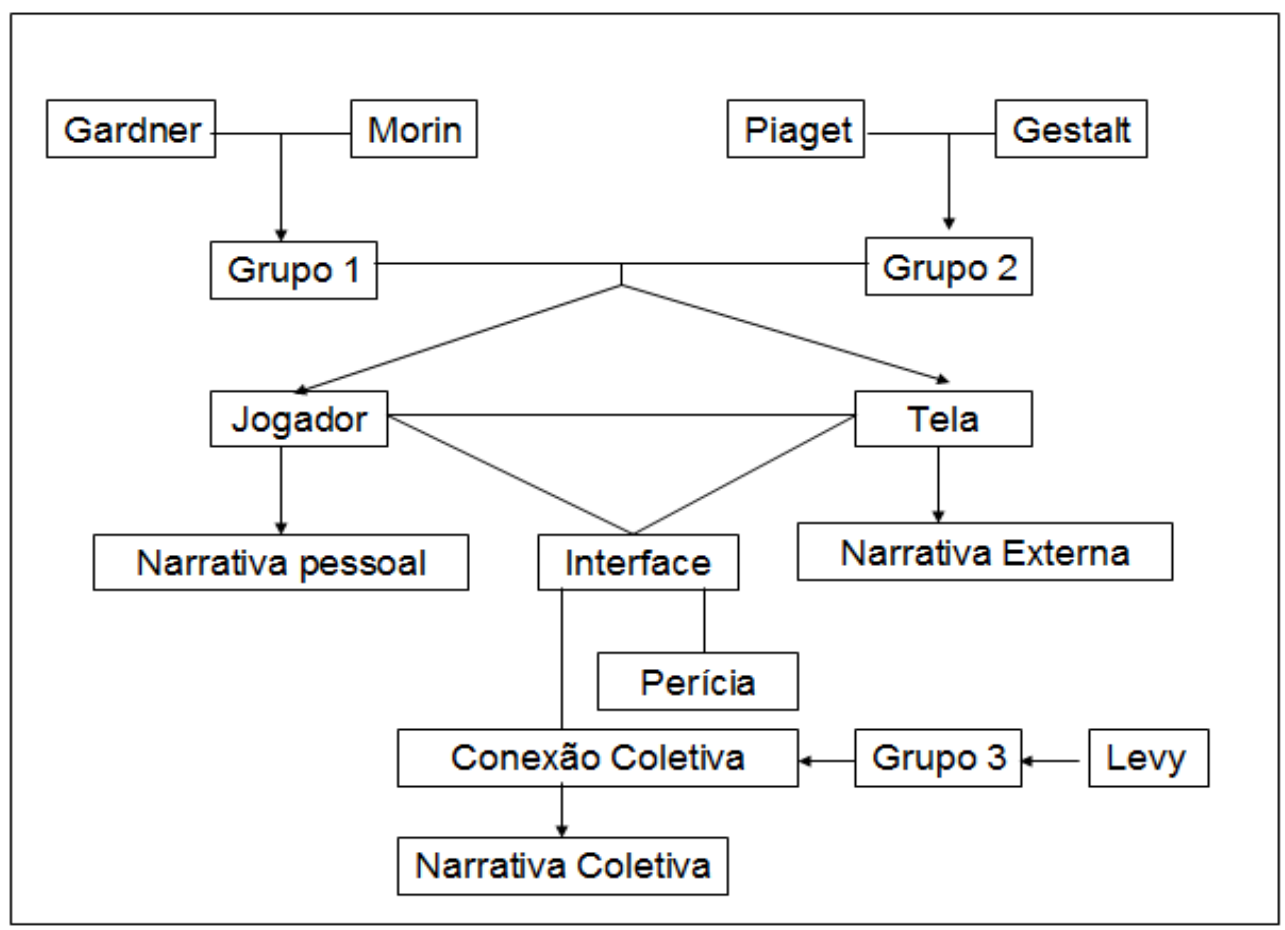

Figura 1 - Esquema de conexão entre autores e temas

Fonte: Organizado pelo autor

O jogador interage com a mídia de maneira lúdica, o que o leva a desenvolver interesse e promover essa atividade. $\mathrm{O}$ modo que ele tem para interagir com a tela é a 
interface, que pode ser o mouse, o joystick, o touch e até mesmo os sensores de movimento. Cada uma das ações reflete diretamente em resultados expressos na tela, o que pode variar de acordo com as habilidades. O tempo empenhado em relação ao jogo melhorará a perícia do usuário, pois toda evolução tem sua curva de aprendizagem expressa de forma visual.

Quando falamos sobre a tela em relação aos videogames, nos deparamos com a questão da ubiquidade, ou seja, a informação pode ser acessada por diferentes plataformas que permitam trocar dados entre si. Em função de estes fluxos informacionais serem estabelecidos pela internet, temos a possibilidade de interação com pessoas remotas formando uma comunidade não presencial (HILLIS, 2004), baseada em relacionamentos virtuais, formação de grupos, tendências e demais práticas que possam ser transformadas como: a diversão pura e simplesmente; o ato de relacionar-se; a possibilidade da trocar informações, assistir a vídeos e outras que venham a surgir em função de novas tecnologias.

O grupo 1 está associado às Inteligências Múltiplas (GARDENER, 1995) e à Teoria da Complexidade (MORIN, 2000). Agrupamos a informação associada às habilidades do cérebro e ao caráter multifacetado que atinge estas combinações, tecendo uma malha com diversas relações, não sendo uma forma linear de descrever os caminhos que a mente percorre para assimilar algo.

Unidades complexas, como o ser humano ou a sociedade, são multidimensionais: dessa forma, o ser humano é ao mesmo tempo biológico, psíquico, social, afetivo e racional. A sociedade comporta as dimensões histórica, econômica, sociológica, religiosa (...) O conhecimento pertinente deve reconhecer esse caráter multidimensional e nele inserir estes dados: não apenas não se poderia isolar uma parte do todo, mas as partes umas das outras; a dimensão econômica, por exemplo, está em inter-retroação permanente com todas as outras dimensões humanas; além disso, a economia carrega em si, de modo "hologrâmico", necessidades, desejos e paixões humanas que ultrapassam os meros interesses econômicos. (MORIN, 2000, p. 38)

Essa abordagem possibilitou atribuir uma visão de como os videogames podem atuar frente ao processo cognitivo e como isso pode ser utilizado para aproximação de transmissão de conteúdos para a audiência. Isso ocorre principalmente porque o conhecimento se manifesta de forma holística, ou seja, não apenas em relação à emissão e captação de um dado específico, como também, pelas diversas cadeias e conexões envolvidas no ato de compreender algo (como, por exemplo, vencer um desafio encontrando a solução para ele, usando o padrão de cognição individual). Existindo diversas maneiras para se atingir um 
mesmo objetivo, cada usuário, com suas respectivas habilidades, pode chegar a ele por caminhos diferentes.

O grupo 2 aborda conjuntamente a Teoria da Equilibração (PIAGET, 1977) e o Completamento Gestáltico (ARHEIM, 1966). Focamos a relação entre esses dois pensamentos na intersecção causada entre a emissão e a recepção. O usuário tem motivos e pulsões que o levam a realizar uma atividade, recompensando sua motivação com a estesia de seus sentidos.

Podría decirse que en cada momento la acción se encuentra desequilibrada por las transformaciones que surgen en el mundo, exterior o interior, y cada conducta nueva no sólo consiste en restablecer el equilibrio, sino que tiende también hacia un equilibrio más estable que el que existía antes de la perturbación. En este mecanismo continuo y perpetuo de reajuste o equilibración consiste la acción humana, y por esta razón pueden considerarse las estructuras mentales sucesivas, en sus fases de construcción inicial, a que da origen el desarrollo, como otras tantas formas de equilibrio, cada una de las cuales representa un progreso con respecto a la anterior. (PIAGET, 1977, p. 4)

No caso, qualquer jogo é desenvolvido com códigos de programação, códigos de imagens, símbolos, regras e induções de atos que levam o jogador a ser recompensado na medida em que ele desenvolve as tarefas e os desafios propostos. O ambiente dos jogos, por ser delimitado, cria um espaço de regras e efeitos controlados, logo, tanto a narrativa quanto a mecânica oferecem resultados padronizados que vão diretamente ao encontro do que levou o jogador a querer realizar tal ato no momento ou período de sua motivação.

No grupo 3 focamos a relação com a cultura digital (LÉVY, 2004), criando um novo fluxo de informação, de maneira reversa e personalizada. Nesse contexto, surge a questão da interatividade e do consciente coletivo que traz à tona as conexões interpessoais que se refletem em hábitos culturais (como, por exemplo: comunicação, compras, busca por informações e até mesmo formas de jogar).

Las situaciones y los seres concretos están sumidos en varias frecuencias antropológicas a la vez. Se puede decir que los espacios antropológicos dependen unos de otros porque ningún ser real subsiste en un solo éter, o sin que ninguna comunicación entre espacios venga a alimentarlo. Pero considerado en sí mismo, cada espacio gira sobre él de manera absolutamente autónoma y solo no percibe ni modifica jamás a los otros que según sus principios específicos, trayendo todo a él, solo encontrando en todas partes su propia figura. Seres, entidades concretas, máquinas cosmopolitas atraviesan las cuatro velocidades, pero ninguna puede causar efecto directo en la otra, no puede tocarla. Los espacios antropológicos están en relación, pero según una causalidad sin contacto. (LÉVY, 2004, p. 131) 
Vale ressaltar a questão do coletivo, uma vez que, se o game for do estilo $M M O R P G$ (multiple massive online role play game), em que o jogador vive em universos virtuais, interagindo com o avatar de outros jogadores, a tecnologia estabelece um potencializador para as ações humanas devido ao caráter grupal. Uma das motivações do coletivo está centrada justamente nessa possibilidade de agir conjuntamente, ou seja, trazendo novos tipos de interação (como o envio de bens virtuais, os desafios e as estratégias que levem em consideração o grupo) que refletem de um modo lúdico.

Enfocamos os três grupos descritos acima em um ponto de equilíbrio com Beinhocker (2006), que propõe analisar o comportamento humano baseando-se nas escolhas pela sobrevivência e depois pelo valor potencializando a tecnologia em paisagens artificiais (que podem ser associadas ao aparelho sensorial do indivíduo e suas formas de cognição em relação às configurações de equilíbrio e aceitação). A conexão em rede passa a gerar um nível maior de interação e padronização mediante o suporte tecnológico que oferece resultante para equação que contém os componentes como determinação de valores, usos e até mesmo impulsos. Quando nos referimos ao suporte tecnológico, estamos expressando itens como: representação audiovisual e capacidade de processamento e conexão em rede. Tais itens expressam capacidades de emulação de conteúdos virtuais, como renderização e inteligência artificial. Ambas as terminologias estão diretamente ligadas a resultados visuais em tela, seja pela capacidade de construção de um ambiente convincente pela estética, seja pela interação da máquina em relação ao usuário. As ações permitidas exortam sistemas que o comportamento daqueles que as realizam buscam uma evolução, ou seja, a utilização em função de suas necessidades de fruições estésicas de identidade, carregadas por graus de sentidos dinâmicos. Baseado nesses conceitos, Beinhocker (2006) propõe um sistema de design evolutivo associado a um sistema algorítmico no qual considera:

- adaptação e inovação contínua;

- acumulação de conhecimento;

- descobrimento do ajuste do design;

- emergência narrativa;

- desenvolvimento de recursos.

Em função dos pressupostos teóricos bibliográficos apresentados vemos um ponto coalizão entre Beinhocker (2006) e o conceito de "perpetual beta" (JACOBS; SIHVONEN, 
2011), no qual os jogos, diferentemente de obras audiovisuais, nunca se encontram totalmente finalizados. Em outras palavras, os filmes, após distribuídos, não podem mais ser alterados, precisando para isso de outra versão, já os jogos digitais, devido à conexão com a Internet principalmente web-browser games, MMOs, ambientes de comércio que vendem DLC's (Downloadable content) ou mesmo jogos situados em "cloud computing" e que acompanham o desenvolvimento e a tendência dos jogadores - podem sofrer alterações online e adaptar o conteúdo de acordo com aquilo que os jogadores preferem. O termo Beta advém do jargão técnico da realização de softwares e existem algumas etapas de criação:

- alpha: nesta fase a jogabilidade é implementada, porém detalhes como objetos da cena ainda não estão presentes, mas quase todas suas funções já estão disponíveis e caracteriza-se por testes e alterações;

- code freeze: momento em que o código não é mais alterado e apenas falhas são corrigidas;

- beta: próximo da versão final, onde o código e demais características são fechadas, porém existindo alguns ajustes;

- code release: fase final de correções e controle de qualidade;

- gold test: versão fechada e pronta para a distribuição.

Seguindo a lógica do perpetual beta" sempre haverá possibilidades de expansões de itens, de cenários e de personagens. Os lançamentos de serviços embasam-se na identificação de padrões de consumo e nas necessidades impostas pelo próprio jogo. Há duas formas caracterizadas pelo Banco Mundial sobre essa produção e consumo de bens virtuais (LEHDONVIRTA; ERNKVIST, 2010):

- micromonetização: compra de itens, muitas vezes por valores ínfimos, em que o produtor ganha na escala do produto;

- microworking: quando as empresas monitoram os clientes e lançam produtos baseados em suas escolhas, oferecendo itens de acordo com as tendências apresentadas no jogo, caracterizando uma espécie de pesquisa sem a percepção do usuário.

Apesar de os autores indicarem o microworking como design participativo, perguntase na verdade, qual seria a real participação dos jogadores, uma vez que geralmente nem sabem que suas contas estão sendo monitoradas e não existe nenhum caráter participativo por parte deles. Sobre a relação entre economia e audiovisual, podemos dizer que ela pode ser compreendida entre cada um dos grupos teóricos abordados previamente. Trata-se de uma forma econômica que se embasa nos princípios da questão audiovisual, não havendo diferença 
entre o ícone e o bem virtual, pois a edificação do fetiche reside na forma de estruturação da cadeia de produção que se faz encoberta por uma série de processos, indo desde a necessidade criada ou imposta, que necessita ser aplacada em função do objetivo que busca ser superado. Questões como a cognição, a transmissão de conteúdos e até mesmo a narrativa que emerge ganham fatores que empoderam aquele conteúdo imagético, sendo que sua posse representa muito mais do que a vitória: exprime a relação de equilíbrio em relação a si próprio.

\subsection{Jogando com os olhos}

O contexto audiovisual e o jogo possuem ligações que se manifestam por meio da observação. Considerando que a imagem tem três possíveis estágios (estático, cinético e cinético interativo), exaltamos experiências na imagem parada e em uma possível jogabilidade, ainda que este seja um estágio de pré-jogo, mas que de modo sutil apresenta características que minimamente tangenciam o jogo. Valendo-se do binômio entre a narrativa embutida e a narrativa emergente, o olhar pode desencadear reflexões internamente no interator (como propostas de desafios e soluções). É como uma espécie de regulamentação que necessariamente não vai tomar outro tipo de forma a não ser à "razão durante" a ocorrência daquela fricção entre o fruidor e a obra (MARCONDES, 2010). Cria-se um pico de êxtase frente à temporalidade metapórica, desenvolvendo um vínculo lúdico entre o usuário e a obra. Valendo-se das leis gestálticas (como continuidade, segregação, semelhança, unidade, proximidade, pregnância e fechamento) ou até mesmo de conceitos como a abordagem nipônica do Yu-gen (a qual pode ser traduzida como mistério, em que os elementos podem ser percebidos por aqueles que observam associado ao filtro pessoal), a pregnância da imagem na retina e no cérebro revela um tipo de sentido, de modo que inicialmente se pode ter uma conclusão, podendo surgir posteriormente, dúvidas e confusões. Esta relação daquilo que é mostrado e de como o cérebro capta a imagem atribui sentidos e ressignificações que podem ser explorados como forma de entretenimento. A lista é composta por uma série de passatempos associados a questões de matemática, geometria, ou até mesmo de como "encontrar onde está o Wally".

Isto cria uma ambiência de "círculo mágico" de estesia desencadeada pela linguagem estética que desenvolve ações próprias, mesmo que veladas, em função da obra e um vínculo 
lúdico, indo da brincadeira ao desafio. Relacionando o "círculo mágico" à imagem e à estética nipônica, temos o conceito Enso (traduzido como círculo).

Muito mais do que uma forma geométrica e do que suas especificações técnicas de como realizá-lo à luz da filosofia zen, o círculo vale-se de uma estrutura que permite a observação daquele espaço vazio, onde haverá o completamento por parte do indivíduo, uma espécie de espelho que não reflete a imagem externa, mas uma tela projetiva de si próprio conforme sugere uma das interpretações possíveis a esta híbrida técnica de arte e meditação. A imagem, independente de qual seja, desenvolve a capacidade projetiva daquele que a observa.

Perante a questão estática da imagem, obras como as de Escher criam construtos visuais desafiando a lógica da natureza formal exigindo atenção para entender as incongruências com a realidade e suas perspectivas, dialéticas de formas e a representação de movimentos na tela, estruturas que levam a uma compressão da realidade adversa nas leis em que estamos inseridos.

Ao subverter essa ordem, a confusão gerada e a busca pelo discernimento da realidade levam a um estágio de pré-jogabilidade. É como se a tentativa de compreensão e da busca pelo diferente impulsionassem a uma maneira de pensar, para encontrar os erros, colocar naquela circunstância e buscar os espaços vividos no cotidiano com as distorções apresentadas, como nas imagens a seguir: 


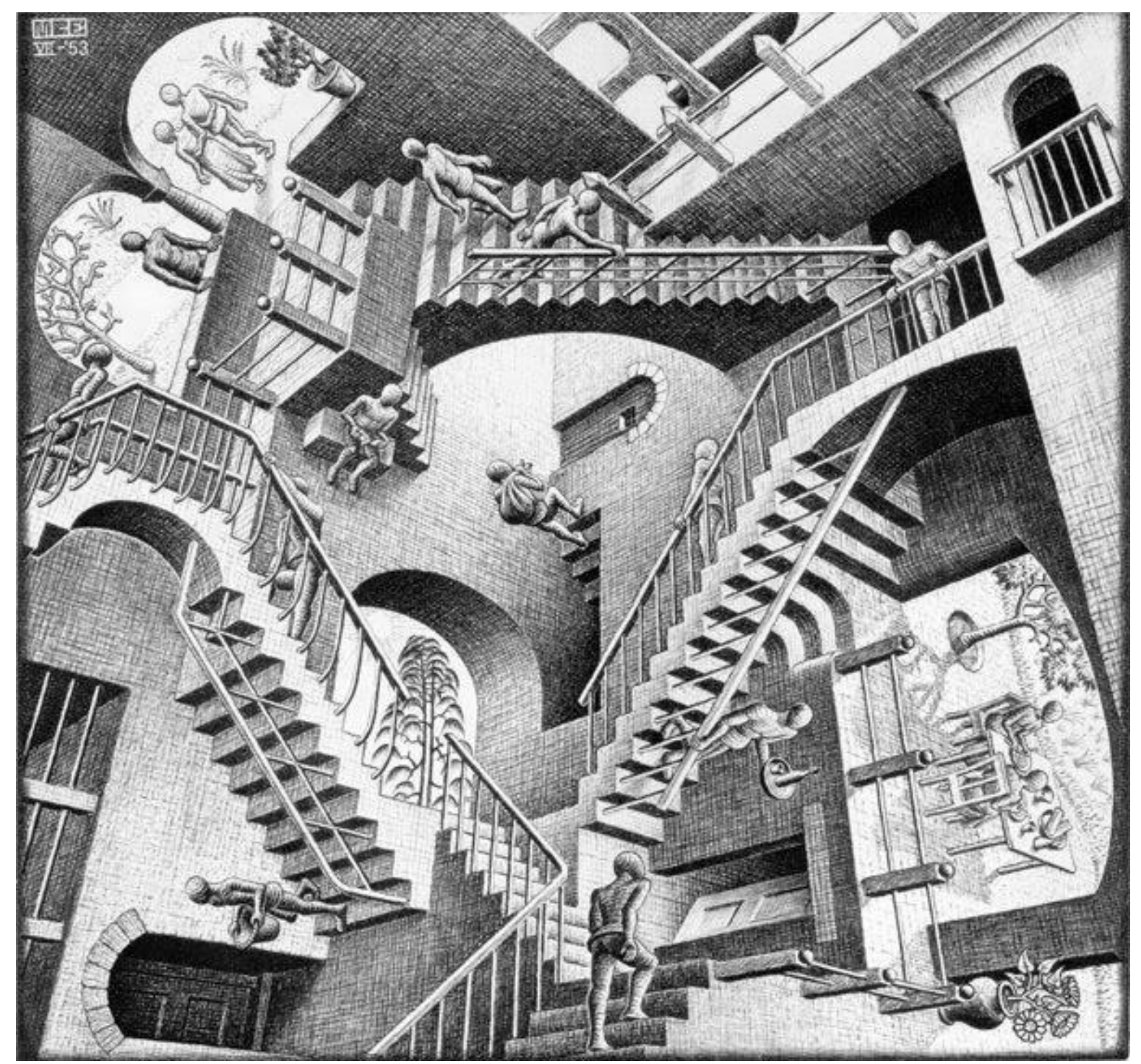

Figura 2 - Relativity.

Fonte: Meridian. Disponível em: <http://www.meridian.net.au/Art/Artists/MCEscher/Gallery/Images/escherrelativity-lithograph-medium.jpg > 


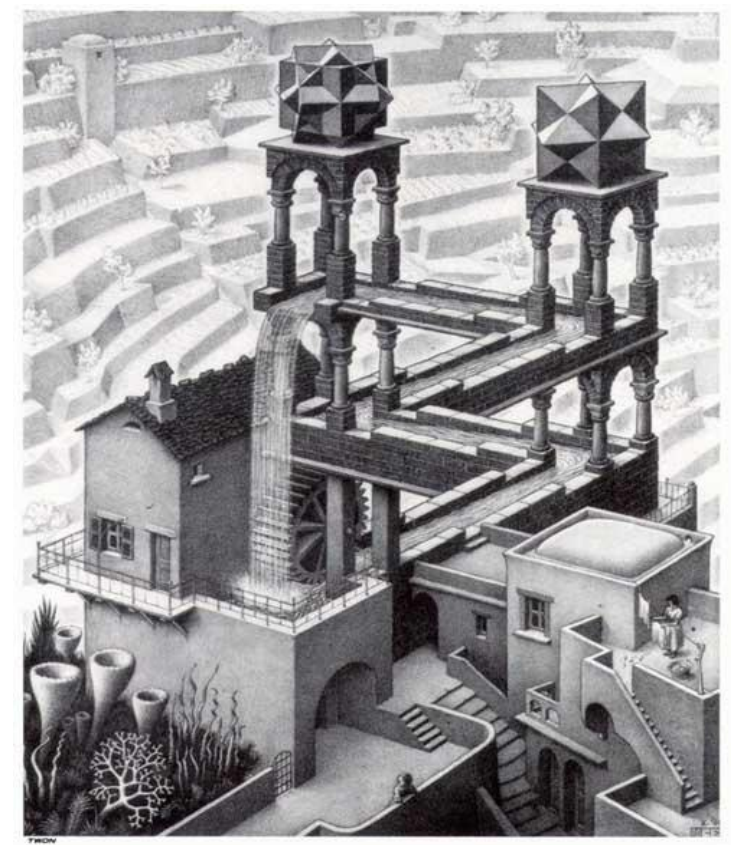

Figura 3 - Waterfall

Fonte: Meridian. Disponível em: <http://www.meridian.net.au/Art/Artists/MCEscher/Gallery/Images/escherwaterfall-medium.jpg>

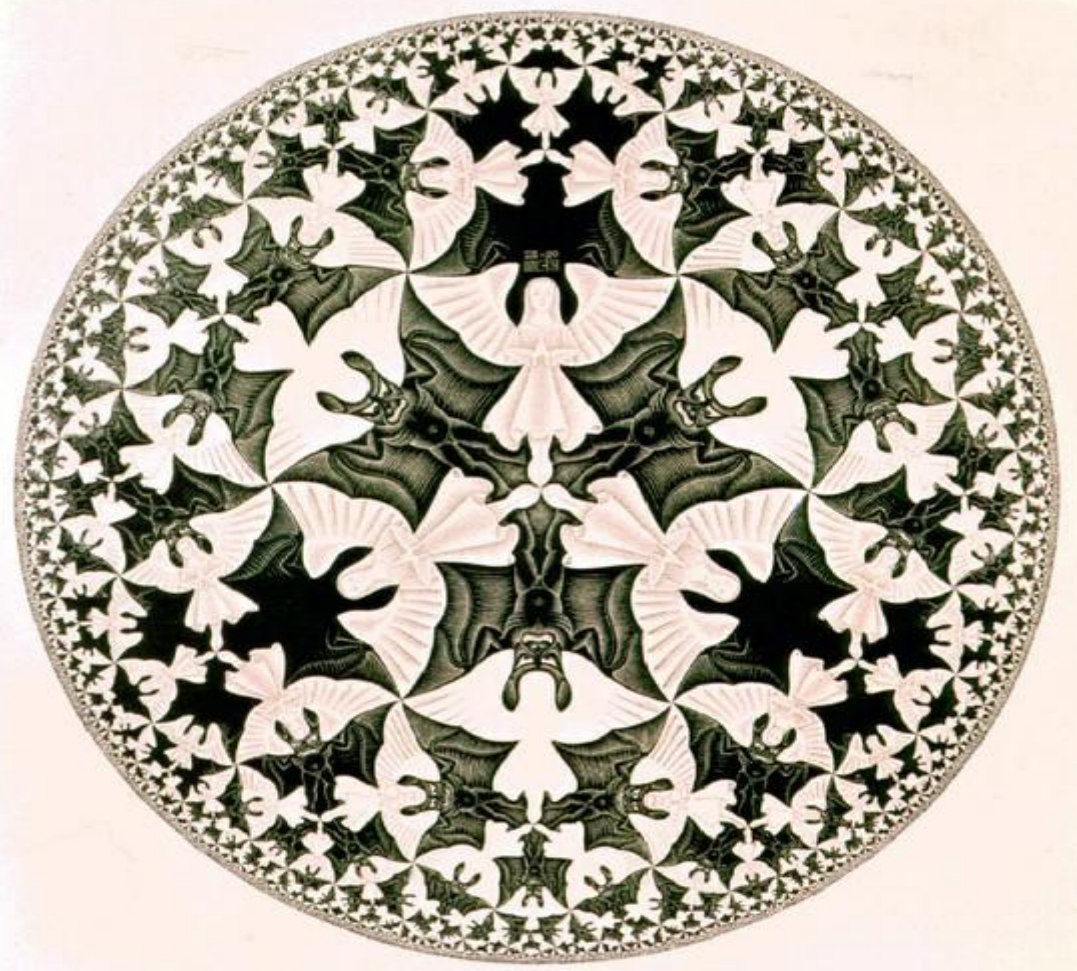

Figura 4 - Limite Circular IV.

Fonte: Universidade de Lisboa. Disponível em:

<http://www.educ.fc.ul.pt/docentes/opombo/seminario/escher/circular4.html > 
Atualmente, existem dois jogos que utilizam e evidenciam a arte de Escher ao game design, no qual o personagem precisa ir de um ponto a outro através das construções paradoxais baseadas no artista. É uma espécie de puzzle geométrico associado aos jogos de plataforma no estilo de aventura. Echochrome ${ }^{3}$ e Adynatopia $^{4}$ : ambos os jogos despertam no usuário as mesmas sensações e reflexões que acontecem com as imagens de Escher, criando possibilidades de interação mediante aquele espaço impossível, projetando, assim, para situações de desafios contextualizados com os referidos jogos.

Ao abordar a questão do audiovisual, vale ressaltar que as imagens são anteriores ao cinema, mostrando que é próprio do gênero humano manipular e interagir com elas. Diversos registros encontrados embasam-nos nessa afirmação, como: brincadeiras feitas com as mãos projetando sombras nas paredes (900 a.C. $)^{5}$; teatro chinês de sombras, datado do ano 121 da nossa era; experiências de Leonardo da Vinci e Girolamo Cardano (século 16); lanterna mágica de Athanasyus Kirchner (século 17). Além desses, há outros exemplos de personalidades que desenvolveram pesquisas que resultaram em aparatos voltados à experiência da imagem. Tal inércia culmina no cinema e a evolução continua para outros aparatos e formas de ver a imagem cinética: a televisão, os monitores de computadores, os arcades, a realidade aumentada e até mesmo os vidros inteligentes.

Em relação à questão fílmica, ela representa outra maneira de o olho interagir com a imagem, pois o cinético permite novas abordagens em relação ao estático. Tal como um game designer, o realizador cria uma regra de visualização da sua obra, na qual as técnicas usadas culminam no resultado final. Situações diversas são mais fáceis e rápidas de serem captadas e compreendidas pelo espectador quando projetadas em uma tela, diferentemente de uma descrição em que situações diversas são redigidas, em que se precisa de várias páginas e da habilidade do autor para descrevê-las de maneira clara e detalhada para refletir o seu real sentido.

De acordo com Manovich (2001), a obra de Dziga Vertov representa uma obra fílmica na qual existe uma ludicidade em que está implícita a emergência de uma nova mídia. $\mathrm{Na}$

\footnotetext{
${ }^{3}$ Disponível em: <http://www.gamespot.com/echochrome/videos/echochrome-official-trailer-1-6174497/>

${ }^{4}$ Disponível em: < http://www.kongregate.com/games/iiaopsw/adynatopia>

${ }^{5}$ Disponível em: <http://www.precinemahistory.net/>
} 
construção de Vertov, na exploração dos planos, o olho, a linguagem e até mesmo o simbolismo criam uma cadeia de sentidos que necessita de uma acurácia do olhar para captar e decodificar a linguagem específica que está na tela.

It proves that it is possible to turn "effects" into a meaningful artistic language. Why in the case of Witney's computer films and music videos the effects are just effects, while in the hands of Vertov they acquire meaning? Because in Vertov's film they are motivated by a particular argument, this being that the new techniques to obtain images and manipulate them, summed up by Vertov in his term "kino-eye," can be used to decode the world. As the film progresses, "straight" footage gives way to manipulated footage; newer techniques appear one after one, reaching a roller coaster intensity by the film's end, a true orgy of cinematography. It is as though Vertov re-stages his discovery of the kino-eye for us. Along with Vertov, we gradually realize the full range of possibilities offered by the camera. Vertov's goal is to seduce us into his way of seeing and thinking, to make us share his excitement, his gradual process of discovery of film's new language. This process of discovery is film's main narrative and it is told through a catalog of discoveries being made. Thus, in the hands of Vertov, a database, this normally static and "objective" form, becomes dynamic and subjective. More importantly, Vertov is able to achieve something which new media designers and artists still have to learn - how to merge database and narrative merge into a new form". (MANOVICH, 2001, p. 212)

Exemplificando, tanto o filme $O$ homem com uma câmera (1929) quanto o clipe $T V$ Show (2012) precisam ser vistos várias vezes para se estruturar a cadência da construção das imagens, seus símbolos e suas dinâmicas. Essa constante visualização emerge como uma espécie de jogo, despertando no espectador um desafio, cuja recompensa é estabelecer vínculos de compreensão. $\mathrm{O}$ ato de jogar é algo que existe e persiste por repetidas vezes, não terminado enquanto houver demanda da atenção do jogador, diferente de outras obras (como um livro ou um filme) em que apenas um contato inspira a experiência de fruição. Neste caso, há um processo que vai muito além de uma espécie de gamificação do audiovisual, em que certos itens são assimilados como jogo (uma vez que existem regras e codificações simbólicas) tanto por quem realiza quanto por quem assiste, permitindo codificação por parte do realizador e decodificação por parte do usuário.

Exemplos de práticas lúdicas realizadas em obras audiovisuais:

- easter eggs - brincadeiras que podem ser feitas com o público, em que detalhes que muitas vezes passam despercebidos são colocados no filme, mas que, quando identificados, dão a sensação de recompensa àqueles que conseguem captar o sutil detalhe. Exemplificamos isso com os filmes Kick Ass (2010) - no qual existem diversas referências a um público fã de quadrinhos - e Planeta dos Macacos: A Origem (2011) - em que se tem uma noção de questões que ficaram subentendidas no primeiro filme da franquia (O Planeta dos Macacos, de 1968). 
- cameo apparences - quando alguém interpreta a si mesmo ou determinado diretor tem o hábito de aparecer em seus filmes, como Alfred Hitchcock, Stan Lee, Quentin Tarantino, entre outros.

- sequências após os créditos finais - quando, depois dos letreiros, entra um clipe que sugere uma continuidade da história, um trailer, uma reflexão ou simplesmente a conclusão de algo apresentado na trama. Alguns filmes, como os da Marvel-Fox, estão modificando o hábito do espectador nas salas de cinema, pois, tradicionalmente, a saída do público se dá tão logo se iniciam os créditos finais. Com esta alteração, aguardar até a cena configura-se como uma espécie de recompensa.

Exemplos de obras audiovisuais que brincam com a capacidade de observação do usuário:

- She-Ra (1985), animação em que um dos personagens ficava escondido no cenário e ao final indagava os espectadores, perguntando se havia sido descoberto e mostrando onde estava durante aquele episódio. Isto gerava uma espécie de atenção permanente durante todo o desenho animado;

- Cloud Atlas ${ }^{6}$ (2012), filme em que histórias se cruzam em tempos diferentes, os atores interpretam diversos papéis ao longo da obra e o uso de máscaras e de maquilagens dos personagens passa desapercebido à primeira vista, uma vez que entender a história é o mais importante. Quando o filme termina, fica evidente o papel de cada personagem fazendo com que se tenha vontade de assisti-lo novamente. Isto desencadeou na Internet uma série de guias para melhor compreender o filme, situação gerada pela demanda da necessidade de conhecimento por conta das dúvidas que ele provocou. Todas essas correlações de variáveis sugerem àqueles que assistem a esse filme a possibilidade de interpretações subjetivas, tais como: uma cultura espiritualista associada à reencarnação; uma leitura quântica de ações interconectadas; uma reflexão histórico-materialista de cunho dialético da luta de classes; uma visão niilista do futuro.

\footnotetext{
${ }^{6}$ Disponível em: 〈http://www.youtube.com/watch?v=0hCgCPj8Kdc>
} 


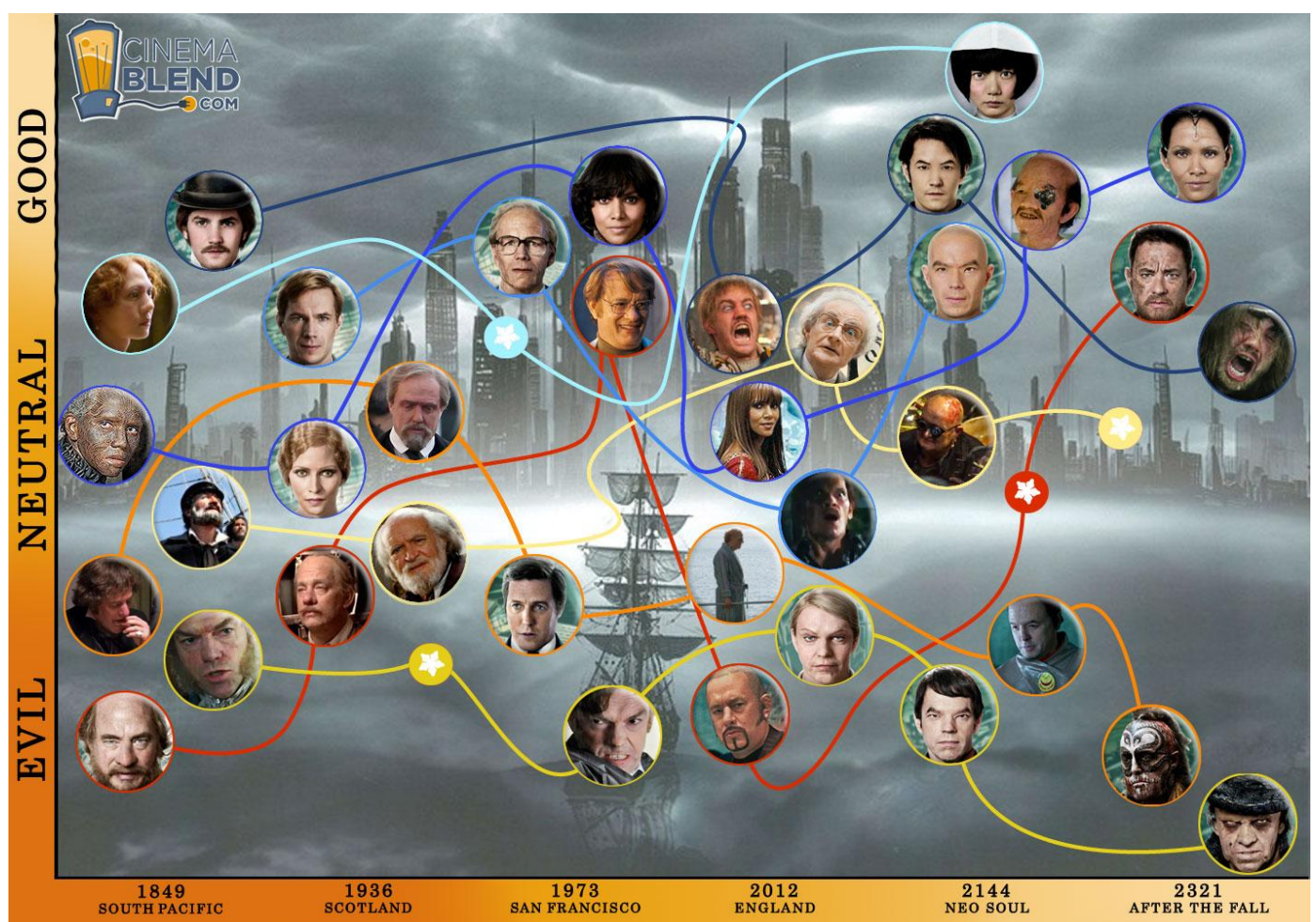

Figura 5 - Quem é quem no filme Cloud Atlas

Fonte: Cinema Blend. Disponível em:

<http://www.cinemablend.com/images/news/33823/_1351547825.jpg>

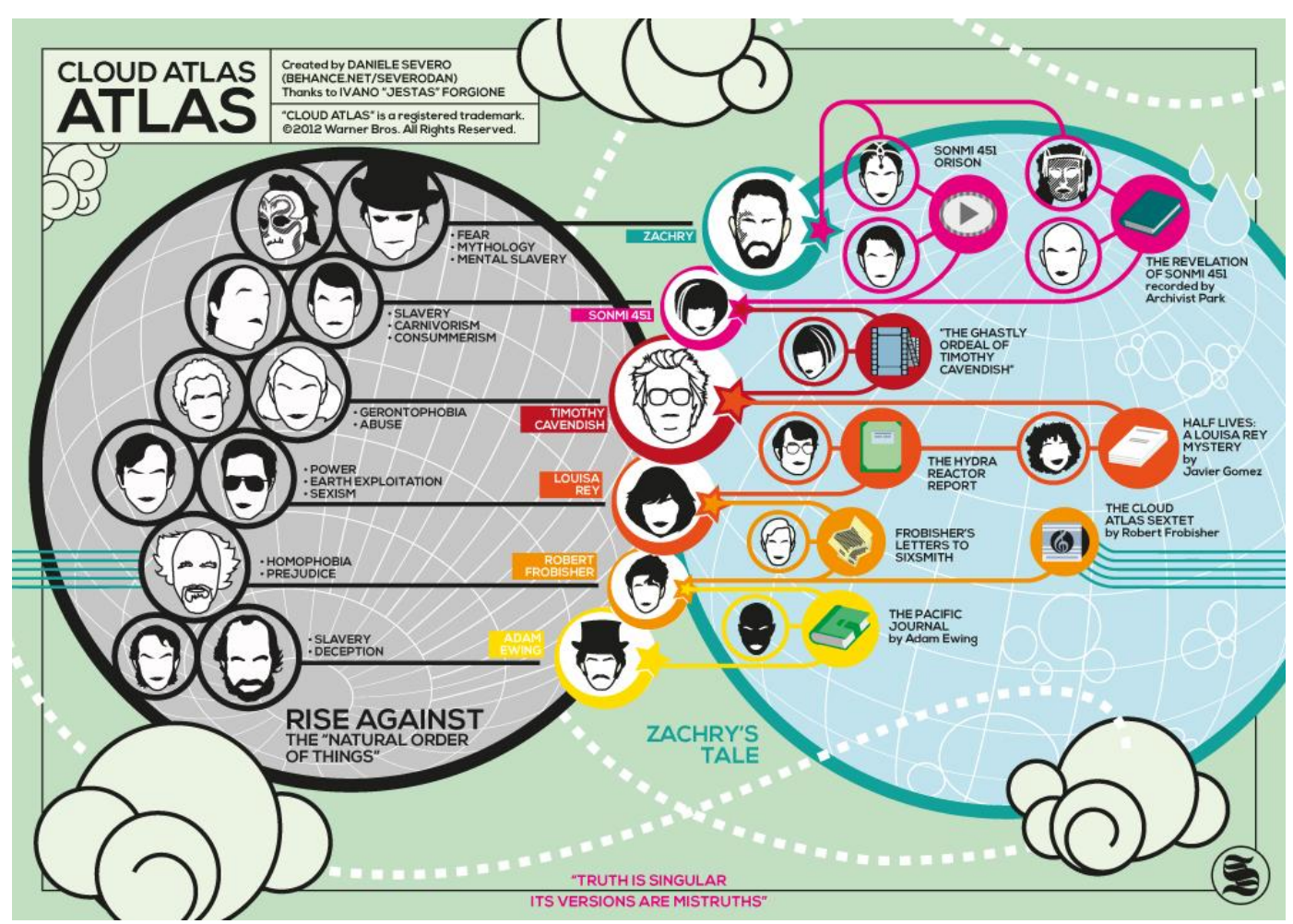

Figura 6 - Infográfico para compreender o filme Cloud Atlas

Fonte: Eazy World. Disponível em: <http://kc-eazyworld.exteen.com/20121226/cloud-atlascharacter-infographic> 
O potencial lúdico de observação da imagem em qualquer que seja sua natureza está contido no sistema estabelecido entre o espectador e o realizador em diversas formas e diretamente associado à criatividade, ou seja, com possibilidades infinitas. As técnicas empregadas poderão desencadear um processo de observação, reflexão e envolvimento com a obra de modo que oriente a observação e a ludicidade, desencadeando uma espécie de envolvimento.

Uma leitura que podemos fazer da pertinência do jogo em relação a outros meios está intimamente voltada ao modo com que o usuário é motivado para reagir diante do que lhe é proposto. Pensando tanto em Huizinga (2001) com o círculo mágico quanto em Campbell (1976) com o conceito de Axis Mundi, temos uma esfera que se manifesta entre os olhos e a mente do usuário e a tela.

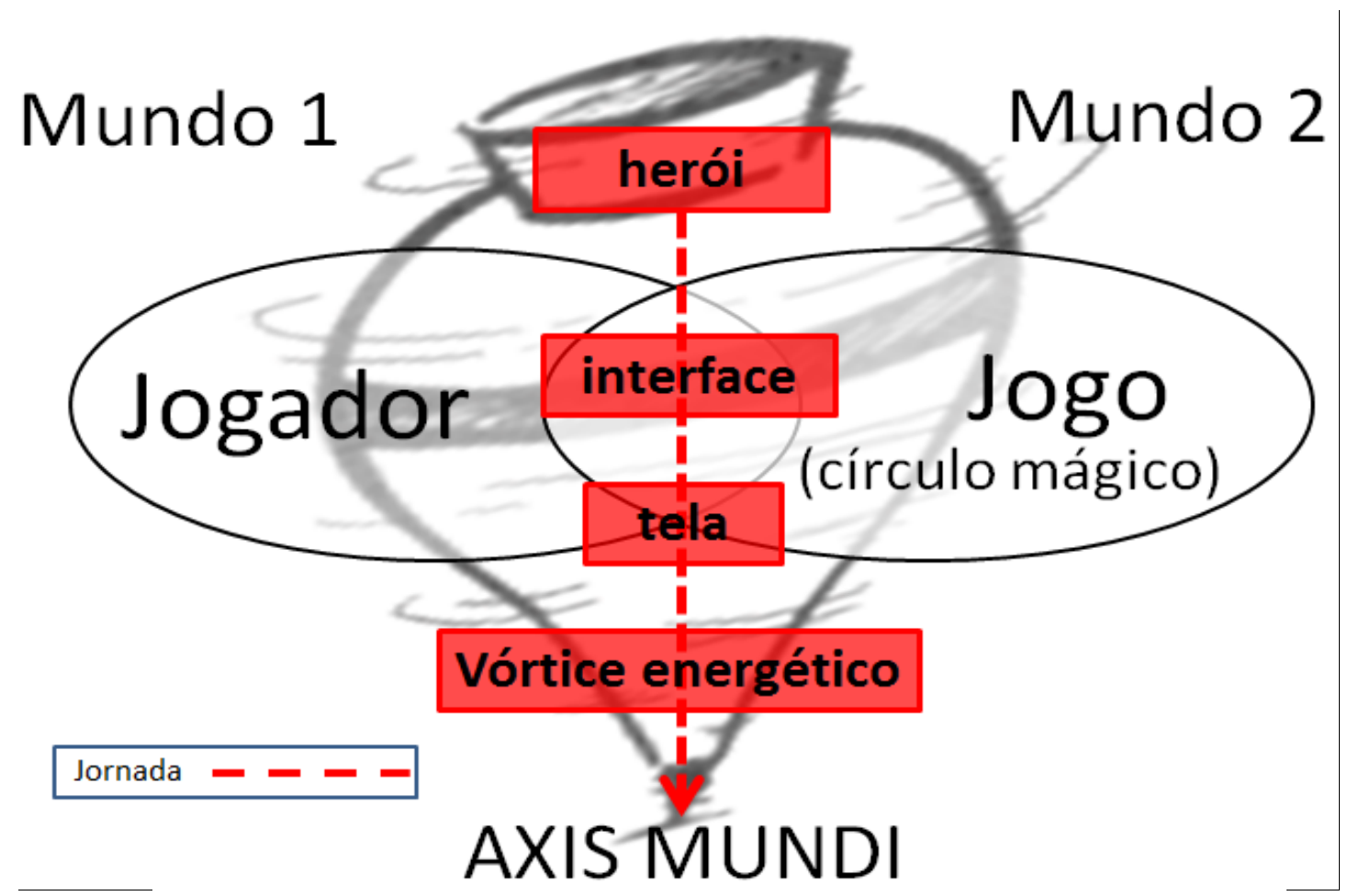

Figura 7 - Axis Mundi na interface do Jogador e do Jogo Fonte: Organizado pelo Autor

Isso possibilita promover uma experiência que direciona o usuário. Nesse momento, pode-se criar um vínculo entre o espectador e a obra, porém, esse vínculo apenas ocorrerá se a obra e a subjetividade conjugarem-se dialeticamente em motivação, tal como podemos observar na Figura 7. 


\subsection{Documentário como forma de registro e de pesquisa aplicado aos videogames}

Jogos de Videogame e documentários podem ser associados como conteúdos audiovisuais distintos, porém a visão proposta pretende estabelecer formas de relações que propiciem uma base para a compreensão, análise e até mesmo criação. A ideia foi exaltar os vínculos possíveis de relação entre o videogame e o documentário, estabelecendo uma cadeia biunívoca, considerando como um pode ser fonte para o outro.

A narrativa da qual o videogame se vale é dividida em duas categorias:

- a primeira, chamada de narrativa embutida, é aquela cujo roteiro foi idealizado por seu criador e na qual a história que está no documento de game design é jogada do começo ao fim e acopla-se com a mecânica de interação do jogo;

- a segunda, chamada de narrativa emergente, é aquela que se origina da experiência do usuário, sujeita a questões da percepção como leitura subjetiva e distorção seletiva do interator.

Obras narrativas complexas não necessariamente significam epopeias épicas, haja vista grandes sucessos, tais como Pac-Man (1980) ou Angry Birds (2009), nos quais o conjunto de símbolos na tela, quase que em um grau icônico ou pictórico das imagens e dos sons, não apenas criaram títulos de sucesso, mas também, fenômenos da cultura popular, extrapolando a questão do jogo e ganhando as ruas, com arte Urbana, camisetas e uma vasta gama de outros materiais (como utensílios domésticos, por exemplo). Independente da representação gráfica (de pixeis amontoados na tela com ruídos até a representação gráfica da última geração com sonoridade polifônica), ao decodificarmos os sentidos, os significados e os verbos de ação dos jogos, encontramos elementos que se identificam com a vida cotidiana de nossa sociedade, época e de nossas matrizes naturais pré-lógicas, socioafetivas e culturais midiáticas. Hillis (2004) analogamente traça um paralelo entre questões históricas e simbólicas da tecnologia, na medida em que relaciona o episódio da marcha para o oeste que ocorreu no passado norte-americano em função da necessidade de desbravamento do território; o mesmo acontece com a cultura da realidade virtual e a exploração da paisagem em jogos de videogames e ambientes virtuais.

Nesse aspecto, a relação entre o jogo e o documentário fica diretamente associada à pesquisa, na qual vemos a busca em retratar a realidade na apropriação de sensos criativos e nas forças motrizes humanas impulsionadoras de mudanças ou inquietações. Temos, de um 
lado, processos simbólicos contextualizados e, de outro, a interface. O documentário torna-se uma base de compreensão e de estudo para os videogames, seja para compreender a origem daquilo que está presente na tela, seja para trazer referências históricas, simbólicas, visuais, sonoras, etc.

Os documentários valem-se do videogame no sentido de romper limites e paradigmas, pois as imagens cinéticas que outrora eram o complemento das imagens estáticas estão em constante ritmo de mudança em direção ao futuro, aproximando-se da tecnologia interativa, de suporte, de armazenamento, de projeção, etc. O fato é que o costume ao acesso da imagem esbarra em novos equipamentos que se popularizam, que não só inovam na condição de como assistir, mas cada vez mais alteram relações como a produção e a distribuição dessas imagens, criando terminologias específicas e classes diferenciais de uso, como os prosumers (aqueles que produzem e também consomem o produto) e os chord-cutters (aqueles que deixam de pagar televisão a cabo em função de novas opções de internet). Porém, independentemente do nome que essas classes de usuários possam receber, todas buscam se relacionar com o futuro da produção audiovisual de uma ou de outra forma. Devido à natureza de qualquer aparelho que possua uma tela e acesso à internet (smart TVs, celulares, tablets, laptops, etc.), ocorre uma convergência de uso, instrumentos periféricos e até mesmo de linguagens. Por exemplo, hoje em dia, tudo que pode ser obtidos via download em ambientes de aquisição recebe o nome de aplicativo (apps). Esse arquivo executável é dotado de interatividade e até mesmo de customização por parte de seu usuário, porém, não existe uma única função desse aplicativo, podendo ser um livro virtual, uma calculadora financeira, um jogo, ou algo que dá acessos a filmes e mais uma infinidade de utilidades.

Da mesma maneira que tocar na tela (para disparar um tiro, colocar algo na cesta de compras, virar uma página, postar um comentário de um vídeo compartilhado em uma rede social, etc.) a interface permite uma operação interativa e intuitiva que abre espaço à manipulação lúdica do conteúdo, seja ele qual for. Algo que pertencia majoritariamente à mecânica dos games, cada vez mais é incorporado por outras maneiras de negócios que possibilitam interagir com a informação disponibilizada. A prática de associar mecânicas de game design com situações que a princípio não tem nada a ver com o jogo recebe o nome de gamificação, que significa ludificar o conteúdo, tornando-o mais divertido e mais atrativo, 
atraindo a atenção e o engajamento do usuário. Listamos algumas estratégias usuais voltadas a aplicativos e conteúdos audiovisuais:

- feedbacks: são as consequências advindas de ações promovidas por toques na tela que resultam em onomatopeias e signos visuais (que podem ou não resultar em alguma forma de pontuação);

- rankings: são os comparativos de desempenho entre o usuário e seus amigos, induzindo à competição;

- condecorações: são as premiações de medalhas para ações diversas (tais como: reconhecimento do acesso diário do aplicativo, ato de convidar amigos, etc.);

- realização de missões e recompensas: quando a conquista de objetivos propostos resulta no ganho de pontos e/ou medalhas (por exemplo, ver cinco filmes de gêneros diferentes para ganhar a insígnia correspondente);

Estas práticas citadas acima, cada vez mais presentes em nosso cotidiano têm como objetivo a fidelização do usuário, fazendo com que ele permaneça o máximo possível usando aquele aplicativo, sendo estimulado pelas recompensas.

Além da gamificação, o hipertexto é outro aspecto no qual os videogames podem contribuir com os documentários, pois os jogos digitais promovem a combinação de linguagens múltiplas e de interatividade. Tal prática consiste em expor itens midiáticos de uma forma variada e conectada e, assim, torna-se uma experiência única quando é acessada. A construção tecnológica do hipertexto é chamada de cibertexto, no qual imagens, links, textos e jogos podem compor a chamada literatura ergódiga, em que cada vez que acessada, de acordo com as histórias e escolhas, existe uma forma de "ler o conteúdo", baseada nas preferências subjetivas do usuário naquele momento. Em vez de navegar pelo conteúdo de maneira linear do começo ao fim, é permitido ao usuário um maior grau de autonomia para escolher como a informação poderá ser acessada (AARSETH, 1997). Um documentário pode ser desmembrado em opções semelhantes aos livros de aventura-solo, com escolhas ramificadas e acessadas de acordo com o interesse do leitor. Outro exemplo é a navegação pelo cenário filmado ou modelado em 3D, que permite explorar livremente o espaço de maneira subjetiva ou em terceira pessoa, onde a câmera segue o protagonista.

Existem hoje diversos games são feitos baseados na estética de documentarização de um episódio, nos quais em vez de empunhar uma arma, o avatar precisa reunir informações, como no jogo Conflitos Globais (2006). Há, também, outras formas de relação entre os jogos 
e os documentários, de modo que as informações de um complementam as do outro, gerando assim um fluxo de interesse biunívoco.

Aprofundando a questão do contexto fílmico e do hipertexto, temos a possibilidade de edição cinematográfica junto com a edição do cibertexto, como se fosse uma nova proposta de leitura e de escrita. Outro ponto ressaltado é quanto à relação tecnológica e visual de caráter ergódigo que o cibertexto promove, onde observamos um ponto de equilíbrio entre a configuração "gestáltica" (ARHEIM, 1966) e os processos heurísticos de escolhas que objetivam os pressupostos da inteligência artificial (RICH; KINGHT, 1991). Werner Herzog propõe que fatos criam normas e que iluminação traz a verdade, pois existe algo poético, que o mistério e que a alusão podem ser atingidos através de construção de imaginação e sinalização.

Nesse contexto, a "inércia evolutiva" dos filmes para os games pode ser relacionada a Manovich (2001) e a Franco (NCE-USP, s.d.). O primeiro autor propõe a evolução das telas e a segunda autora, a evolução dos princípios que compõem a matriz da linguagem audiovisual. Associando as duas ideias à criação e à persuasão narrativa temos uma situação fílmica que pode ser apenas imaginada pelo espectador. No jogo a situação proposta na tela é experimentada, o que ocasiona situações diferentes, dependendo da percepção e da perícia de cada usuário.

Por exemplo, no jogo Sonic (1991), controla-se um porco-espinho azul que corre atrás de moedas flutuantes e enfrenta bichos mecânicos; em Darfur is Dying (2009), o personagem pertence a uma minoria étnica cujo vilarejo sofre com a falta de água e, por isso, precisa correr para buscá-la em um reservatório, tendo que se esconder pelo caminho de milicianos armados para não ser morto. No primeiro caso, temos um personagem fíctício; o entretenimento populariza um estilo de jogabilidade e encerra-se em si próprio. No segundo caso, temos um fato que acontece atualmente na África e, mais que o desafio, a realidade é documentada e vai muito além de uma simples memória, pois tal registro reforça a responsabilidade frente à sociedade (AUMONT, 2004). Assim, a alteridade criada promove sensibilização, permitindo a comunicação "face a face" perante um estado de "razão durante" e entre o objeto audiovisual e o usuário. (MARCONDES, 2010).

Outro fato de ligação entre as narrativas não-ficcionais e os videogames são os newsgames, jogos baseados diretamente em notícias, partindo-se do pressuposto de que a 
informação pode ser conseguida, também, jogando. Existem jogos de relevância como o September 12th (FRASCA, 2007), em que o jogador dispara bombas em Cabul para atingir terroristas. Em um cenário de destruição acentuado pelos disparos, mais e mais revoltosos surgem até que a cidade tomada por rebeldes fica completamente em ruínas. Nesse caso, temos uma mecânica de jogo em ciclo e não concludente, que promove no jogador uma experiência de reflexão de fatos da vida real, mostrando que a guerra e a violência apenas agravam um processo. No jogo é divulgada uma série de links e informações com denúncias sobre a reação antiterror promovida pelos Estados Unidos desencadeada após o atentado de 11 de setembro.

Das duas formas propostas em relação à convergência de documentários e videogames, nos ativemos à questão do documentário como um elemento voltado para a compreensão do jogo, seja enquanto narrativa, seja como experiência estésica que promove fascínio em relação a tipos de jogos como Super Street Fighter IV (2012). Nesse jogo, as histórias individuais se sobressaem, justificando o motivo de o personagem desafiar a própria vida, viajando pelo mundo e digladiando-se com outros lutadores com o objetivo da vitória. Com exceção dos poderes telúricos (baseados em folclore das artes marciais) e em proezas físicas que lembram os filmes chineses (em que atores são suspensos por cabos de aço), as histórias são, em sua grande maioria, associadas a um perfil heróico (como ser o melhor, ajudar a sua comunidade, tornar-se famoso, etc.). Os motivos não são diferentes de qualquer atleta, lutador do Ultimate Fight Championship, ou mesmo de uma pessoa comum com seu cotidiano de superação.

A arena pode ser vista como uma metáfora da superação individual, pois coloca o simbolismo da luta em função de desafios que necessitam ser superados, exigindo o melhor do indivíduo para esta conquista. Para compreender questões comportamentais que envolvem as artes marciais, citamos alguns documentários e vídeos disponibilizados no Youtube que retratam situações de interesse para esta pesquisa:

- a relação entre a identidade pessoal e a luta, como mostrado no documentário Urban Dragons (2011), em que mestres e praticantes de ascendência Hispânica e Africana em Nova Iorque falam do impacto da prática de lutas em suas comunidades e de como isso promoveu orgulho, autoestima, etc.;

- o estudo científico seguindo os modelos de documentários norte-americanos sobre a pesquisa dos movimentos, em que os efeitos gráficos na tela evocam um sensacionalismo e 
que, ao mesmo tempo em que são baseados em testes de laboratório, reforçam crendices e lendas, como no Fight Science (2010);

- a temática sobre os filmes de artes marciais e seu impacto na sociedade foi popularizada no ocidente com atores como Bruce Lee e David Carradine, cujos filmes evocaram questões folclóricas da cultura popular asiática, retratados pelos Samurais, pelos Monges Shaolin e pelos heróis patrióticos da China (como Wong Fei Hung e Hou Yuan Jia). Com a popularização dessa temática e a relação afetiva do público com essas obras, ocorreu uma série de desdobramentos: promoção da prática de artes marciais; estudo de elementos da cultura oriental; aspectos específicos da produção (como técnicas de câmera para captar os movimentos); surgimento de ídolos, como é demonstrado em The Art of Action (2011);

- as competições esportivas profissionais com videogames em que os e-atletas fazem partidas ao redor do mundo, buscando superação pessoal e conquista de prêmios que podem ir desde o respeito pela reputação até dinheiro. Documentários como I Got Next (2011) e o registro de competições no Youtube, mostram como é a vida desses jogadores e a nova prática associada aos esportes digitais;

- a cadeia de sentidos que se desenvolve nos jogadores, como podemos ver em Balrog: Behind de Glory (2012), em que o documentário fictício sobre a vida de um personagem secundário, explora depoimentos do pai e do professor de Balrog sobre sua infância e esta complementaridade frente à história inicial gera um sentido de humor.

A partir dai traçamos paralelos com o jogo, de modo que o exercício pudesse servir para compreender relações entre a temática em função das informações levantadas. Olhar para os documentários escolhidos foi uma forma de investigação que foi além de uma pesquisa inquisitiva, com grau de inquérito e rigores das ciências exatas. As obras escolhidas foram vistas de maneira não passiva, objetivando o proposto por Vanoye e Goliot-Lété (1994) que colocam perante o estudo de uma obra audiovisual a liberdade, de modo que a relação entre o analista e a obra flua e possa haver um vínculo como se fosse um diálogo. Essa orientação de observação pela obra encontra respaldo em Marcondes (2010), através do metáporo na busca por relações que possam contribuir para a pesquisa, levando em consideração as conexões que surgem diretamente no acontecimento ou como o autor chama "face a face", como algo que está em constante formação. 
O procedimento metapórico opera em três momentos da pesquisa: no estabelecimento das condições de possibilidade da mesma e de sua observação, (o "caminhar" nômade) e na apresentação final de seus resultados. (...) Nosso olhar e nossa sensibilidade buscam identificar vetores, relações, processos, o elemento paradoxal, o acontecimento, a dotação de sentido. (MARCONDES, 2010, p. 265)

Utilizamos como guia para nossa observação e postura metapórica frente ao tema, aos objetos de pesquisa, às formas de abordagem e à orientação dos resultados as seguintes considerações:

- do movimento do mundo que é permanente e a nossa inserção nele: a contingência e a transitoriedade;

- do território na investigação: espaço liso (espécie de corpo pleno sem órgãos), suporte para o emaranhado de fios, vetores, linhas, cruzamentos;

- do nosso deslocamento: nômade, errático, em rodeio;

- do olhar: dando precedência à intuição sensível, considerando a atmosfera circundante; focando na captura do processo gerador e nas relações que constituem objetos. 


\section{Abordagens em videogames}

\subsection{Um aspecto da pesquisa em Videogames}

Os videogames representam um fenômeno cultural e econômico de importância relevante comparado à indústria dos filmes, da música ou até mesmo do mundo esportivo, haja vista a relação entre jogos que licenciam personalidades sejam elas esportivas, sejam as vozes e as aparências de artistas. De acordo com Aarseth (2001), os games combinam conceitos estéticos de outras mídias de massa (televisão, filmes e teatro) de modo muito peculiar, compartilhando valores da audiência que sustenta mercados, porém acrescendo uma espécie de comunicação estabelecida pelos próprios usuários. Para a compreensão do videogame enquanto ciência e como novo campo de estudos, esse autor refere-se a dois termos específicos: "revolução comunicativa" e "nova disciplina".

Devido à natureza audiovisual e interativa que os games permitem, eles são objeto e processo, já que para se obter a experiência oferecida, não se pode apenas ler, ouvir ou contemplar as imagens de maneira passiva, necessita-se jogar, ato que exige atenção completa, além de um envolvimento criativo. O ambiente proposto pelos games, voltado à simulação, está apoiado em três bases: sorte, habilidade e criatividade. Este tripé é apoiado em bases estéticas, das quais citamos a arte - visual e sonora - e as estruturas narrativas (AARSETH, 2001). O maior desafio a ser superado é a inserção dos games no mundo acadêmico.

A teoria específica do estudo dos videogames é precedida pela prática (FRASCA, 2007), pois antes dos jogos serem estudados, foram criados, aperfeiçoados e jogados. Os videogames derivam, de um lado, de hábitos e práticas sociais e, de outro, da situação tecnológica na qual se vive. Atualmente, podemos ver de um lado os jogos servindo para quebrar barreiras da limitação cultural de hábitos e cultivar práticas ligadas a caminhos de aplicações sem vínculos com a ludicidade e, de outro, servindo para diversos fins associados às praticas econômicas, inclusive pesquisas de tendências, ecossistemas econômicos ligados a marcas, entre outros. Várias atividades associadas ao Kynect (aparelho voltado à leitura do corpo para interação com a tela), após alguns anos de seu lançamento, tiveram 
desdobramentos extrapolando o próprio jogo, como, por exemplo, seu uso em áreas da saúde como clínicas de fisioterapia.

Os estudos associados aos jogos digitais encontram-se em um campo relegado a outras áreas, tais como: antropologia, engenharias diversas, programação, sociologia, narrativas, semiótica, etc. Há um vasto campo de demanda para pesquisa, que pode contribuir para melhorar a concepção desse mercado em relação à sistematização de conceitos e ao pensamento crítico frente à sociedade.

Para Parlett (1999), a questão acadêmica apresenta um paradoxo entre a utilização corriqueira e a visão na universidade, pois perante o senso comum é fácil compreender e entender o que é um jogo, uma narrativa e suas questões correlatas, porém, quando esse discurso é investido de teoria, fatalmente cairá em outros campos, tais como o da literatura associado a estéticas literárias, buscando correntes como narrativas da literatura de séculos passados. Pesquisadores como Espen Aarseth, Roger Caillois, James Paul Gee, Warren Motte, David Partlett, Erick Zimermann, entre outros, criaram um filtro de possibilidades heurísticas, valendo-se de teorias de outras áreas e criando visões e articulações com maior afinidade aos jogos digitais, objetivando questões como articulações, materialidade, funcionalidade, tipologia, entre outras, necessárias para a compreensão de elementos essenciais do jogo, voltados para a manipulação e configuração temporal, espacial, casual e para relações funcionais em diferentes formas de produção de informação.

\subsubsection{Definições de jogos}

Teóricos de épocas distintas estudaram o que é um jogo, o que faz um jogo ser um jogo, seus elementos, o nível de associação destes e possíveis padrões de repetições, itens sempre presentes na questão do jogar, do lúdico.

O estudioso Jesper Juul (2003) criou uma tabela que cita o que cada um dos estudiosos definiu como elementos presentes no ato de jogar. Após a elaboração da tabela, classificou os elementos semelhantes em cada uma das definições e posteriormente os agrupou: 
Tabela 1 - Compilação Prévia de definições de jogos

\begin{tabular}{|c|c|c|}
\hline Autor & Data & Definição \\
\hline Johan Huizinga & 1950 & $\begin{array}{l}\text { Uma atividade livre, realizada de modo consciente e que ocorre fora dos } \\
\text { padrões da vida cotidiana, sendo algo que não tem impacto e gravidade } \\
\text { alguma, mas que ao mesmo tempo prende completamente a atenção do } \\
\text { jogador. Trata-se de uma atividade que não pode adquirir nenhuma forma } \\
\text { de lucro. O jogo prossegue dentro de seus próprios limites de acordo com } \\
\text { o tempo e o espaço conforme estabelecem as regras fixas um determinado } \\
\text { tipo de ordem, promovendo a formação de agrupamentos sociais que } \\
\text { tendem a se cercar de sigilo e sublinhar a sua diferença em relação ao } \\
\text { mundo comum com um disfarce ou outras formas de emulação. }\end{array}$ \\
\hline Roger Caillois & 1961 & $\begin{array}{l}\text { Uma atividade essencialmente gratuita, voluntária, desagregada da } \\
\text { realidade no tempo e no espaço, incerta, improdutiva, governada por } \\
\text { regras e que permite o faz de conta. }\end{array}$ \\
\hline Bernard Suits & 1978 & $\begin{array}{l}\text { Para jogar um jogo é necessário estar engajado em uma atividade dirigida } \\
\text { para extrair um estado específico de coisas, usando apenas aquilo que é } \\
\text { permitido pelas regras, onde o regulamento vigente proíbe o mais } \\
\text { eficiente em favor do menos eficiente, e se tais regras forem aceitas, } \\
\text { significa que elas tornam possível tal atividade. }\end{array}$ \\
\hline $\begin{array}{l}\text { Avedon \& } \\
\text { Sutton Smith }\end{array}$ & 1981 & $\begin{array}{l}\text { Em seu nível mais elementar, jogo é um exercício de sistemas de controle } \\
\text { voluntário em que há uma oposição entre forças, confinadas por um } \\
\text { procedimento, em que as regras têm o objetivo de produzir um resultado } \\
\text { desequilibrado. }\end{array}$ \\
\hline Chris Crawford & 1981 & $\begin{array}{l}\text { Possui quatro fatores comuns: representação (sistema fechado formal que } \\
\text { subjetivamente representa um subconjunto da realidade), interação, } \\
\text { conflito e segurança (resultados de um jogo são sempre menos duros em } \\
\text { relação àquilo que eles representam em relação à vida real). }\end{array}$ \\
\hline David Kelley & 1988 & $\begin{array}{l}\text { Um jogo é uma forma de recreação composta por um conjunto de regras } \\
\text { que determinam o objetivo a ser atingido e um meio plausível para } \\
\text { alcançá-lo. }\end{array}$ \\
\hline $\begin{array}{l}\text { Katie Salen \& } \\
\text { Eric } \\
\text { Zimmerman }\end{array}$ & 2003 & $\begin{array}{l}\text { Um jogo é um sistema no qual os jogadores se envolvem em um conflito } \\
\text { artificial, definido por regras e que termina com um resultado } \\
\text { quantificável. }\end{array}$ \\
\hline
\end{tabular}

Fonte: Juul (2003), traduzido livremente e modificado pelo autor

Após a compilação dos autores que Juul executou, foi criado outro quadro cujo eixo constava quatro classes: o jogo como sistema formal, o jogador e o jogo, o jogo e o resto do mundo e outras questões. No outro eixo: regras, recompensa, objetivos, interação, segregação em relação ao mundo real, questões menos significativas, lazer, formação de grupos sociais e ficção. 
Tabela 2 - Relação entre o jogador e o jogo de acordo com as definições prévias

\begin{tabular}{|c|c|c|c|c|}
\hline & $\begin{array}{l}\text { O jogo como } \\
\text { sistema formal }\end{array}$ & $\begin{array}{l}\text { O jogador e o } \\
\text { jogo }\end{array}$ & $\begin{array}{l}\text { O jogo e o resto } \\
\text { do mundo }\end{array}$ & Outros \\
\hline $\begin{array}{l}\text { Regras } \\
\text { Regras fixas (Huizinga) } \\
\text { Regras (Caillois) } \\
\text { Regras (Suits) } \\
\text { Procedimentos e regras (Avedon \& } \\
\text { Sutton-Smith) } \\
\text { Sistema Formal (Crawford) } \\
\text { Regras (Kelley) } \\
\text { Regras (Salen \& Zimmerman) }\end{array}$ & & & & \\
\hline $\begin{array}{l}\text { Recompensa } \\
\text { Incerta (Caillois) } \\
\text { Disequilibrial outcome (Avedon \& } \\
\text { Sutton-Smith) } \\
\text { Changing Course (Kelley) } \\
\text { Recompensa Quantificável } \\
\text { (Zimmerman \& Salen) }\end{array}$ & & & & \\
\hline $\begin{array}{l}\text { Objetivos } \\
\text { Bringing about a state of affairs } \\
\text { (Suits) } \\
\text { Oposição (Avedon \& Sutton- } \\
\text { Smith) } \\
\text { Conflito (Crawford) } \\
\text { Objetivo para ser atingido (Kelley) }\end{array}$ & & & & \\
\hline $\begin{array}{l}\text { Interação } \\
\text { Interação (Crawford) }\end{array}$ & & & & \\
\hline $\begin{array}{l}\text { Objetivos, regras e o mundo } \\
\text { Conflito Artificial (Zimmerman \& } \\
\text { Salen) }\end{array}$ & & & & \\
\hline $\begin{array}{l}\text { Segregação } \\
\text { Outside ordinary life / proper } \\
\text { boundaries (Huizinga) } \\
\text { Segregação (Caillois) } \\
\text { Sem interesse material (Huizinga) } \\
\text { Sem produtividade (Caillois) }\end{array}$ & & & & \\
\hline $\begin{array}{l}\text { Sem relação com o trabalho } \\
\text { Livre/ Voluntário (Caillois) } \\
\text { Controle Voluntário } \\
\text { (Avedon \& Sutton-Smith) } \\
\text { Recreação (Kelley) }\end{array}$ & & & & \\
\hline $\begin{array}{l}\text { Less efficient means } \\
\text { Less efficient means (Suits) }\end{array}$ & & & & \\
\hline $\begin{array}{l}\text { Grupos sociais } \\
\text { Promove agregação social } \\
\text { (Huizinga) }\end{array}$ & & & & \\
\hline $\begin{array}{l}\text { Ficção } \\
\text { Representação (Crawford) } \\
\text { Faz de conta (Caillois) } \\
\text { Segurança (Crawford) }\end{array}$ & & & & \\
\hline
\end{tabular}

Fonte: Juul (2003), traduzido livremente e modificado pelo autor 
Feitas essas compilações, Juul (2003) determinou seis elementos necessários que compõem um jogo:

- Regras: jogos são baseados em regras;

- Recompensa: resultado como uma variável quantificável;

- Valor atribuído a resultados possíveis: valorações diferenciadas entre aquilo que é positivo e o que é negativo;

- Esforço do jogador/desafio: o jogador se esforça com o objetivo de influenciar o resultado;

- Conexão entre o resultado e o jogador: a ligação se manifesta ou como resultado positivo com o vencedor feliz, ou como negativo, com o perdedor infeliz;

- Consequências negociáveis: o conjunto de regras pode ser jogado com ou sem consequências na vida real.

Gonzalo Frasca (2007), em sua tese de doutorado, fez um levantamento semelhante ao de Jesper Juul, listando teóricos e as respectivas opiniões sobre eles:

- afirmou que Huizinga era um interessado no ato de jogar perante o contexto cultural em geral; que seu livro é um texto de ampla erudição sobre temáticas abrangentes como poesia e guerra; que focou seus esforços para demonstrar como atividades lúdicas, existentes desde a antiguidade, são um vasto campo para pesquisas acadêmicas;

- considera Brain Sutton-Smith o mais importante estudioso do jogo vivo. Dedicou-se a estudar a limiaridade dessa atividade e tal condição é expressa pela grande diversidade que o jogo apresenta;

- quanto a Callois, para cada um de seus itens de classificação de jogo é feita uma descrição: 1) liberdade - o jogo não é obrigatório, se fosse, seria perder sua atratibilidade; 2) individualidade - circunscrito dentro dos limites de espaço e tempo, definidas e fixadas com antecedência; 3) incerteza - durante o qual não pode ser determinado, nem o resultado pode ser obtido previamente, sendo que a atitude inovadora é deixada a critério dos jogadores; 4) improdutividade - não criar bens nem riqueza, nem elementos novos de qualquer tipo, com exceção para a troca de bens entre os jogadores que termina em uma situação idêntica à existente no início do jogo; 5) regido por regras - são convenções que suspendem as leis ordinárias que param o momento e estabelecem nova legislação, logo permitindo o item 6) faz de conta - acompanhado por uma atenção especial de uma segunda realidade ou irrealidade de um livre, que se opõe à vida real. 
- perante a definição de Salen e Zimmerman, alguns pontos são enfatizados: 1) jogos devem ser considerados como sistemas, com elementos que interagem entre si, dentro de certos limites; 2) jogos envolvem um conflito, o que significa que os jogadores terão de enfrentar algum tipo de desafio (esse conflito é artificial no sentido de que é separado da vida real); 3) jogos são definidos por regras, as quais delimitam os jogadores, as ações e as características do sistema; 4) jogos devem gerar um resultado quantificável e isso pode ser um resultado, ou simplesmente um julgamento (ganhar ou perder).

Para Frasca (2007), a definição de Jesper Juul (2003) tem grande sinergia com o modelo apresentado por Salen e Zimerman (2007). Frasca faz questão de pontuar sua opinião sobre a classificação de Juul:

1. Os jogos têm resultado variável: a expressão de termos como "variável" ou "quantificável" deixam-no confuso, pois, se existe a possibilidade de quantificar o resultado de um jogo, o resultado é necessariamente variável. Exemplificando com o quebra-cabeça que, como tem só uma forma de ser resolvido, pode ter seu resultado considerado variável ou não.

2. Jogos requerem esforço do jogador: expressa que o jogador deve ter algum envolvimento com essa atividade, seja física, seja mental, e tais ações incidem diretamente no resultado;

3. Jogadores sentem-se ligados ao resultado: considera um elemento importante, pois este traz à jogabilidade individual, traduzindo-se nos motivos da jogabilidade, em que cada indivíduo encontra razões próprias para jogar e para interpretar o desafio, as questões de sucesso, os fracassos e toda a interpretação simbólica em geral.

4. Consequências do jogo são opcionais e negociáveis. Significa que os resultados podem ter um raio de ação baseado em outros elementos que extrapolem a situação de jogabilidade. Para Juul (2003), consequências na vida real são estipuladas pelos jogadores, algo que não havia sido concebido no jogo originalmente. Existe a consonância entre Juul (2003) e Salen e Zimerman (2007) sobre a existência de uma segregação entre o jogo e a vida real, porém, ocorre uma dissonância em relação à artificialidade do jogo: segundo Juul (2003), para isso ocorrer é necessário o acordo do jogador; segundo Salen e Zimerman, o jogo sempre será artificial. Após estas análises sobre definições de jogos, para a experiência de game designer que deve ser levada em conta, Frasca propõe:

A game is to somebody an engaging activity in which players believe to have active participation and where they agree on a system of rules that assigns social status to their quantified performance. The activity constrains players' immediate future to a set of probable scenarios, all of which they are willing to tolerate. (FRASCA, 2007, p. 70) 
Para o autor, jogo é definido pelos seguintes itens:

- Os jogos são sociais: são empreendimentos sociais por excelência;

- Os jogos são atividades lúdicas e objetos: além de atividades, são objetos, no qual existe algum tipo de expressão de materialidade. As vitórias e derrotas condicionam performances e eventos;

- Os jogos têm regras: são sistemas controlados, em cujas definições são estabelecidas condições de sucesso e de vitória;

- O desempenho do jogador é medido e avaliado: a atuação do jogador é quantificada enquanto performance, porém isto varia em relação a questões individuais e coletivas;

- Jogadores acreditam participar ativamente nos jogos: associado diretamente ao comportamento do jogador, uma vez que este coloca sua intenção em transformar aquilo que ocorrer naquele exato momento, mesmo sendo um jogo de chance (azar).

- Consequências do jogo não são opcionais: trata-se da viga mestra desta definição e permite a melhor compreensão da ambiguidade dos jogos.

Há uma série de definições e exemplificações empíricas de como construir um jogo e de como definir esses constructos, porém, nos ativemos às terminologias de Juul (2003), devido à sistematização criada por ele e à preocupação de exemplos ligados à fronteira entre o que são e o que não são jogos. Gonzalo Frasca (2007) fez uma análise do estudo de Juul e depois desenvolveu sua própria classificação de jogos. Porém, seu trabalho e os jogos que ele desenvolveu, de certa forma, tendenciam sua classificação sugerindo a interpretação dedutiva de sua construção, limitando o escopo e a abrangência da abordagem dos jogos. A visão de Juul (2003) é mais ampla e seu sistema foi proposto a partir de algo que se aproxima de um modo indutivo e estruturalista em função dos exemplos utilizados.

De acordo com Parllet (1999), para a devida compreensão dos games é necessária uma abordagem referente ao contexto digital e midiático. Jogos são sistemas que possuem a finalidade de gerar consequências e significados mediante atividades processuais com regras que permitem manipular algum tipo de equipamento. Jogos são práticas configurativas e a situação de jogar é algo que combina fins, meios, regras, equipamentos e ação manipulativa. Através do ato de jogar ocorre uma interação de ordem temporal que incide em questões de causa e espaço. Isto se resume em três fatores: 
- situações: a história por si só e seus respectivos elementos;

- eventos: ações e acontecimentos diferenciados pelo grau de importância que ocorrem diretamente em relação à narrativa, determinando o grau de relevância entre o que está mais próximo ou à margem do centro;

- existências: divididas em duas partes (as relativas ao personagem e às demais características significantes ao enredo). Pela forma como se entremeiam, servem para determinar características relevantes associadas a diversos graus de identidade e temperamentos que existam na história.

Esses três níveis narratológicos foram embasados no teórico Chatman (1978) que já tínhamos encontrado em Dubiela e Battaiola (2007). Ao buscar diretamente suas referências, encontramos um esquema de estruturação dos elementos que compõe a narrativa que passou a ser utilizada em associação ao gráfico de Juul (2003). O conceito de manipulação de temporalidade vai diretamente ao encontro do conceito utilizado de linguagem audiovisual (edição arbitrária de conteúdo captado), porém a diferença é que, no filme, isso fica por conta do realizador, enquanto no jogo o realizador cria situações para que o jogador possa manipular.

Gregory Bateson (2000) trouxe o exemplo dos Macacos do Zoológico localizado em São Francisco. Mediante a observação do referido autor, constatou-se a situação de lutas de faz de conta entre os macacos que, apesar de simuladas, eram de extrema verossimilhança, porém ficava claro que não estavam se machucando, como se houvesse um acordo tácito entre eles de como funcionava aquela atividade. Tais animais nunca estiveram em uma situação de confronto real, tinham nascido em cativeiro. Algumas atividades realizadas pelo ser humano possibilitam riscos, como os esportes radicais e as artes marciais, nas quais se assume a condição de poder machucar-se ou mesmo causar ferimentos no semelhante. Esse autor indaga, mas não encontra resposta para a questão: como uma forma de combate pode ser um combate e ao mesmo tempo não ser um combate?

Podemos extrapolar esta situação muito além dos games, em que jogos musicais imitam uma guitarra e, mesmo assim, não fazem de seus melhores jogadores músicos (muito embora seja desenvolvida nos usuários uma aproximação com a cultura do rock'n'roll). A mesma coisa acontece com os jogos de luta, nos quais o melhor campeão sequer terá condição de enfrentar um praticante de artes marciais. São estabelecidos elos entre o jogo e a cultura e entre a representação da luta e a luta propriamente dita. Nessa lacuna, desenvolvemos uma 
série de reflexões que serviram para embasar não apenas a escolha pelo objeto de estudo, mas que serviram para aproximar o conteúdo que faz a ambiência do jogo, as formas de estabelecer relações promotoras de cultura, filosofia e tecnologia, bem como as questões associadas à tela e à representatividade da experiência através de estesia, gestalt e inteligência artificial.

Para Manovich (2001), os condicionantes associados às novas mídias em nossa leitura e para os fins desta pesquisa não coadunam com uma definição eficaz de videogame, pois os pontos que embasam sua definição (representação numérica, modularidade, automação e variabilidade) são muito amplos, adequando-se mais a softwares, home pages, aplicativos e processos digitais do que qualquer outra aplicação computacional. De fato, jogos podem ser inseridos nesses itens, porém, ao buscarmos uma linguagem própria e mais aprofundada, tais tópicos se apresentaram de modo genérico e, sobretudo, relegaram a linguagem própria do videogame que estamos buscando, principalmente em relação ao suporte audiovisual que faz a diferença inclusive no sufixo da própria palavra videogame. Porém, Manovich é de extrema valia quando é feita uma classificação sobre a inércia evolutiva das telas e as questões sobre as novas capacidades de configuração do olho humano.

\subsection{A evolução dos jogos no contexto audiovisual}

O ato de jogar é intrínseco ao ser humano, como algo que está na sua natureza, uma ação pré-lógica em consonância com a própria configuração daquilo que o caracteriza. De acordo com a exposição proposta por Huizinga (2001), os paralelos traçados entre diversas culturas, de tempos e origens diferentes, registram o jogo desde os primórdios da raça humana, como algo intrínseco que varia de acordo com níveis tecnológicos refletindo questões culturais como a fé ou até mesmo do próprio vernáculo. Associamos esta relação entre o jogo, o ser humano e a época (Zeistgueist) com a proposta de Galimberti (2006), psiche e techne, em que os jogos sempre existiram e sempre vão existir. Contudo, a época muda, o suporte tecnológico muda o que é codificado, assim como as condições de vitória e derrota. Para esse autor, o ser humano é naturalmente impulsionado por suas carências, sejam sentimentos, sejam questões associadas ao existencialismo e tais dúvidas geram necessidades de respostas ou um conforto para aquilo que não tem uma solução. Dessa maneira, existe o 
impulso de dominação. A psique direciona a tecnhe, sendo então o jogo algo endêmico e autóctone do ser humano advindo de razões que, com o passar do tempo, transformam-se e sustentam-se em outras bases permanecendo intacta a sua função essencial.

Um dos primeiros estudos associados à evolução dos jogos foi desenvolvido, no séc. XIX, por Stuart Culin (Figura 8), etnógrafo que traçava paralelos entre culturas e suas práticas, primeiramente abordando questões ligadas à medicina tradicional chinesa e às práticas ocidentais e, posteriormente, dedicando-se ao estudo dos jogos de povos antigos buscando ligações e sinergias entre a forma e a função de determinados objetos associados à prática dos jogos.

A flecha divinatória (divining arrow) é um instrumento da belomancia - um tipo de “fortune teller"- e é compreendida dentro da rabdomancia, prática divinatória associada a objetos filiformes de madeira, que ao serem arremessados, configuram uma trajetória ao cair com características que criam padrões que podem ser associados à predição do futuro (inclusive uma espécie de I ching feita com varetas). No caso, a flecha era ornamentada com símbolos sagrados, caracterizando-a como objeto-ritual. Após lançada sua trajetória e distância podiam ser utilizadas para procurar água, sinalizar uma direção a seguir ou simplesmente dar respostas. Essa prática foi comum entre gregos, babilônios, scythians (iranianos nômades) e árabes.

Há uma série de passagens religiosas e mitológicas nas quais o arco e flecha eram usados como instrumento sagrado e simbólico: na Bíblia, livro de Ezequiel, capítulo 21, versículo 21; nas civilizações ameríndias; no Budismo/Hinduísmo, as passagens do Mahabarata (inclusive o Bhagavad Gita, com o arco Gandiva) e o Ramayana; no xamanismo mongol; no exercício zen-budista chamado de Kyudô, que consiste no ato de meditar enquanto atira a flecha; no orixá da cultura africana, sendo instrumento bélico de Oxóssi. 


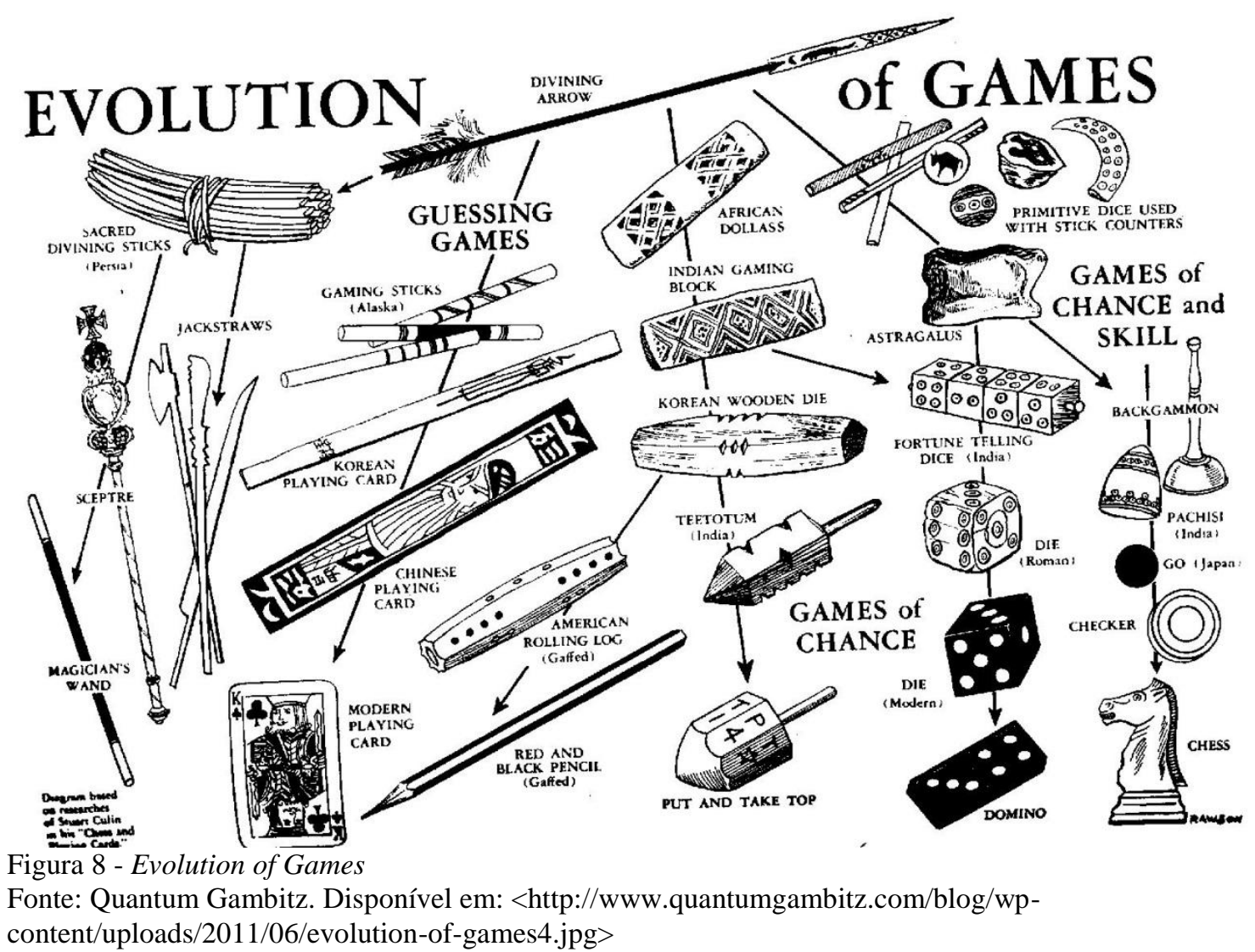

Na Figura 8, vemos um esquema que mostra a evolução dos jogos enquanto prática quotidiana. Através de objetos de fetichismo religioso e telúrico, a evolução destes ganhou praticidade ergonômica em função de matérias primas e da ludicidade do uso, como:

- eixo divino: associados ao uso religioso, porém devido a questões interpretativas e operativas, funcionam como forma de comunicação com o sagrado, como os gravetos de adivinhação que, por sua vez, se subdividem em pega varetas e em objetos litúrgicos/hierárquicos, como cetros e varinhas de condão;

- eixo dos jogos de adivinhar: associados a habilidades de múltiplas variáveis e combinações que necessitam de perícia e ficam ao sabor da sorte, como cartas variadas e o baralho moderno;

- eixo sem nome: associado ao manuseio de artefatos capazes de gerar alguma resposta, com a manipulação influenciando nos resultados visualizáveis. Esse eixo se divide no dado de madeira coreano, no pião e no lápis vermelho e preto; 
- eixos de jogos de chance: associados ao inesperado (astrágalos, dados de rabdomancia, dados modernos e dominó);

- eixo de jogos de habilidade: derivados dos jogos de chance, em que, apesar de existir o conceito sorte, a estratégia pode sobressair-se; é baseado em sistemas da antiguidade que poderiam valer-se de dados ou outros tipos de contadores (gamão, go, damas e xadrez).

Referente a esta imagem e ao que ela expõe, podemos traçar alguns paralelos em relação aos videogames:

- a questão entre a guerra e o jogo: todos estes artefatos derivaram de um objeto militar, a flecha, considerando o nível de sofisticação para se produzir artesanalmente arco e flecha, que ao serem empregados nos tempos livres, derivaram a técnica em função da criação de outros instrumentos para melhorar as ações nos tempos de lazer;

- a relação com o divino: a varinha de condão utilizada em círculos mágicos serve de instrumento para canalizar e focar a atenção do magista, ao passo que tais ritualísticas necessitam da imaginação. Há um caráter de liberdade de pensamento e descontração que permite à mente entrar em "estados de círculos mágicos". Podemos fazer uma relação direta do ato resultante entre o binômio artefato e magia. Desta maneira, os joysticks e os sensores de movimento resultam na tela ações em um mundo virtual expressando uma movimentação específica. Outro aspecto da varinha de condão é a sua utilização por prestidigitadores, com o intuito de desviar a atenção do público quando faziam seus truques de ilusionismo, ou mesmo utilizá-la como apoio em manipulações específicas;

- a relação do inesperado e da sorte: algo que inicialmente promove surpresa e encantamento e, posteriormente, para suplantar o desafio, necessita lapidar a perícia;

- a relação do "feedback": semelhante a uma brincadeira com projeção de sombras: os atos refletem o que está sob controle e, assim, com alguma imaginação pode-se ter alguma maneira de criação que expresse a necessidade de se ver as consequências de seus atos e, por conseguinte, o grau de perícia.

- a relação do aprimoramento estético presente nestes jogos e a evolução desses sistemas: revelam estilo de produção da época em que foram realizados, deixam implícitos uma busca não apenas pela melhor forma do sistema, que ainda está presente, como também, um aprimoramento estético. 
- a relação entre realidade e virtualidade: jogos como Skylandres: Spyro's Adventure (2011) evocam o fetichismo em seu mais completo espectro (ao colocar o personagem físico na base, ele aparece na tela).

O videogame surge quando esses conceitos passam para o suporte audiovisual. Conforme propõe Manovich (2001), as telas evoluíram da visão humana para: telas pintadas para paredes (as canvas), televisão, monitores de computadores e todos os gadgets presentes hoje na vida contemporânea que reconfiguraram o olhar do homem moderno. Aquilo que era compreendido como jogo e em constante evolução, não só foi adaptado ao suporte audiovisual como foi aprimorado, trazendo uma nova linguagem, uma nova expressão e de entretenimento.

A Figura 9 mostra como os jogos evoluíram da antiguidade até o presente, dos jogos divinatórios até os jogos de redes sociais digitais. A "inércia evolutiva” mostra uma série de outras variáveis, em relação à Figura 8, uma vez que existem vários pontos dentro de uma escala temporal em que o hábito de jogar sofria grande influência do nível tecnológico vigente.

Desde os primórdios da humanidade, o jogo, além de suas características de diversão e lazer, teve um teor de materialidade, precisando de foco de atenção necessário para o desempenho dessa atividade, tanto para os que jogam quanto para os que assistem. Artefatos, espaços, uniformes criam e promovem uma atenção relacionada ao estado do jogo, na medida em que existe um dimorfismo, uma fenotipia, que sintetiza o momento, o espaço e o ato. $\mathrm{O}$ contexto visual, acrescido da imaginação, tem papel crucial dentro do contexto. 


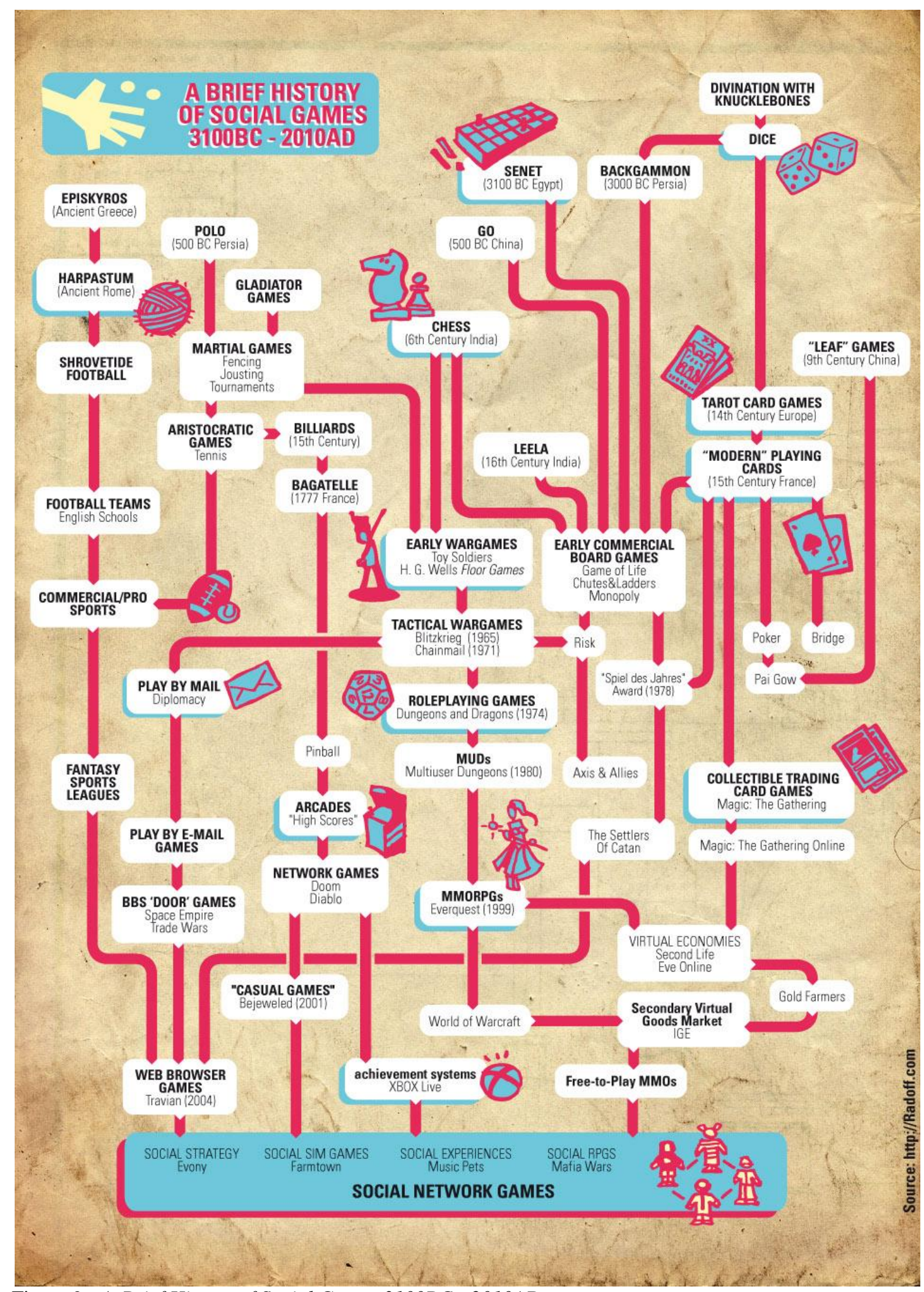

Figura 9 - A Brief History of Social Games 3100BC - 2010AD.

Fonte: Jon Radoff's Internet Wonderland. Disponível em: <http://radoff.com/blog/2010/05/24/historysocial-games/> 
Quando falamos de videogame, de imediato vem à nossa mente a tela, mas antes de esta existir, a Mesa de Bagatelle (combinação dos pin games e sinuca) já era a resultante de experimentos de inventores que relacionavam o ato de jogar com a tecnologia disponível, buscando a valoração da experiência do usuário.

Com isso, podemos listar:

- o equipamento do jogo como um móvel, a edificação de um fetiche, exercendo a relação da experiência associada à aparelhagem específica;

- "feedbacks" rudimentares audiovisuais;

- criação da liturgia do botão e alavancas para interação lúdica, desenvolvimento do hábito de ir a bares, casas de arcade e por fim o console doméstico que evoluiu para as plataformas móveis.

Com a popularização das emissoras, dos aparelhos de televisão e dos equipamentos (como VHS e console de videogame), a tela centralizou o foco de atenção dos usuários. Estar em casa e utilizar o aparelho de acordo com a própria vontade canalizou uma série de atividades: esporte, diversão e até mesmo fé (Figura 9). A tela doméstica evoluiu para a tela móvel e a conexão da internet tornou algo entre recepção e emissão o mais orgânico possível, frente à questão das práticas do ser humano, principalmente em relação aos jogos.

Uma vez que resultados, títulos e partidas de vários jogadores acontecem cada um em seu domicílio com sua respectiva tela, o jogador que visa estar em consonância com as tendências é obrigado a acompanhar o hardware e o software, de modo a estar sempre inserido na rede com outros jogadores, caracterizando assim bases para que possa estar perante a competitividade e seus resultados serem visualizados por todos.

A evolução do contexto do videogame e do audiovisual ocorre em diversas frentes, conforme vemos nas imagens a seguir: 


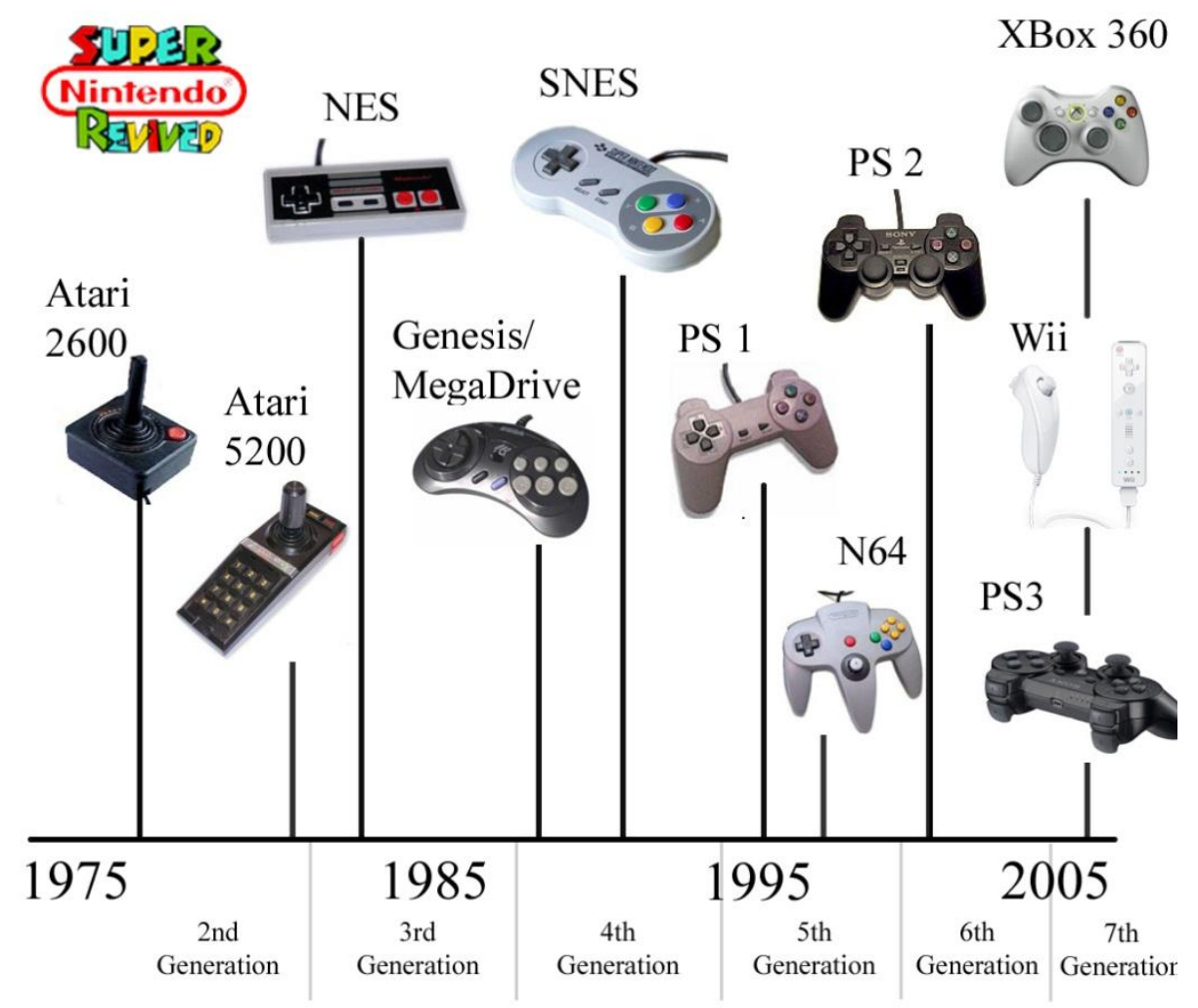

Figura 10 - Evolução dos Joysticks.

Fonte: Snes Revived. Disponível em: <http://www.snes-revived.net/>

Seja em relação ao hardware ou ao software, os jogos evoluem, buscando uma melhor experiência para o jogador, refletindo diretamente em questões de persistência da marca e sua sustentabilidade financeira (Figura 10). A evolução dos joysticks está intimamente ligada à evolução dos personagens, uma vez que a ligação entre o personagem na tela e o jogador é a interface de manipulação. Os controles expressam a ergonomia de como acessar os botões e promover a conexão entre o usuário e tela intermediada pelo console. O Atari tinha apenas um botão e uma alavanca sem a precisão para movimentos de coordenação e ângulos arrojados. Porém, com a evolução dos processadores, as ações também evoluíram. As narrativas desenvolvidas permitiram ao usuário mais botões e direcionais mais precisos, novos tipos de realizar ações (como: pular, atirar, atacar a longa e a curta distância) e movimentos mais detalhados, com até mais de um em um, mesmo controle como o Touchpads que oferece maior interação. Os joysticks também permitem uma navegabilidade por interfaces, por acessarem menus, configurarem questões técnicas (como som, efeitos e cores), escolherem fases e personagens, navegarem na internet, inclusive nos ambientes de comércio de jogos e itens. Os controles são responsáveis por criarem uma relação com o sensório indo além do 
audiovisual, já que são equipados por servos motores e determinados eventos acionam feedbacks táteis, gerando um elo a mais com a experimentação e a imersão do usuário. Em tempos de interfaces remotas como no caso do Kinect e a nova geração dos videogames que está centrada na "cloud computing", o controle é uma peça chave, serve para interagir com o jogo propriamente dito e, por ser um tipo diferente de acesso, para armazenagem e navegação em ambientes que dão acesso aos jogos. Temos isso exemplificado em plataformas como OUYA, Project SHIELD, Xbox 720, o Playstation 4, entre outros.

A evolução dos gráficos advém da evolução do próprio suporte, uma vez que isso permite maior grau de aprofundamento do uso e maior qualidade nas representações que o jogo permite, como a evolução do personagem Ryu, onde é expressa a busca na verossimilhança do personagem que, com o passar do tempo, ganhou uma representação mais realista em seus traços físicos e sua indumentária (Figura 11, 12, 13).

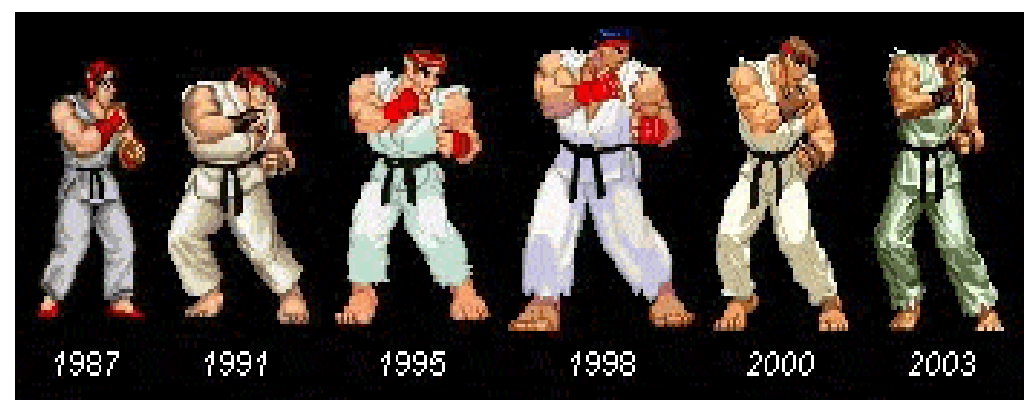

Figura 11 - A evolução de Ryu

Fonte: TRCS gamers. Disponível em: http://trcsgamers.wikispaces.com/file/view/ryuevolution.gif/215036698/ryu-evolution.gif

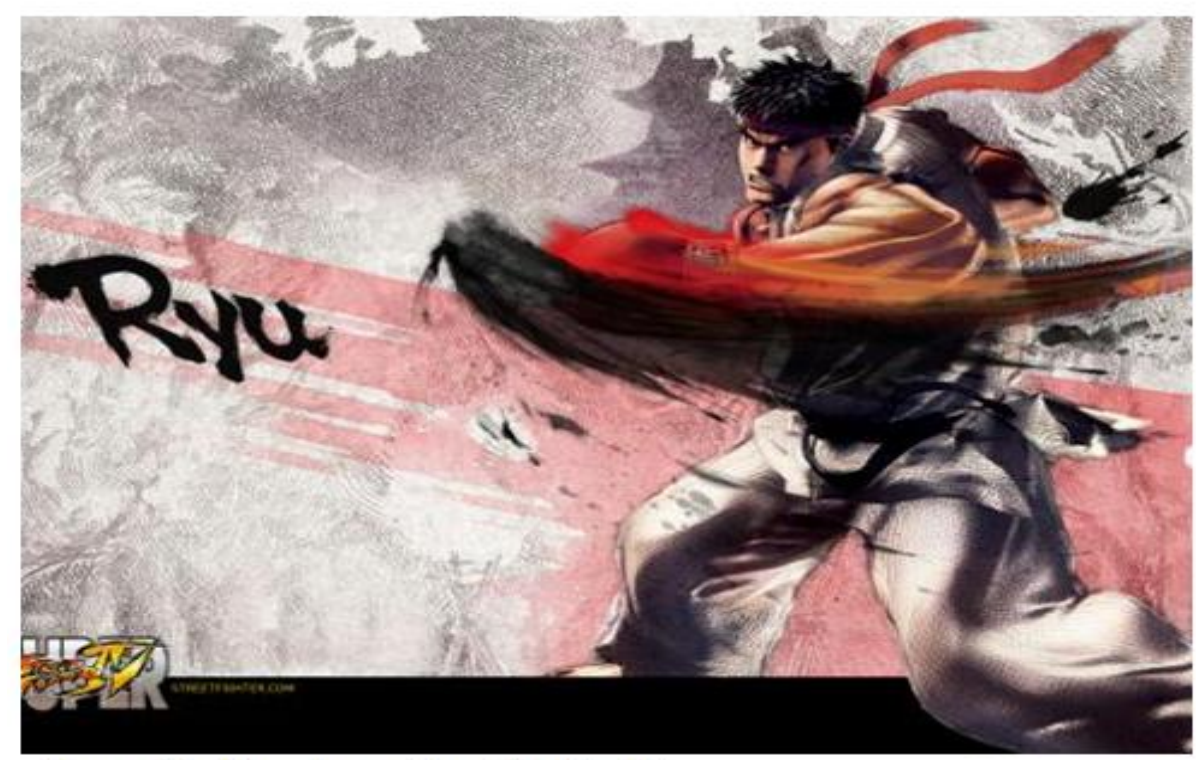

Figura 12 - Ryu, Super Street Fighter IV.

Fonte: HD Papers. Disponível em:

$\measuredangle$ http://www.hdwpapers.com/thumbs/ssf4_ryu_wallpaper-t2.jpg> 

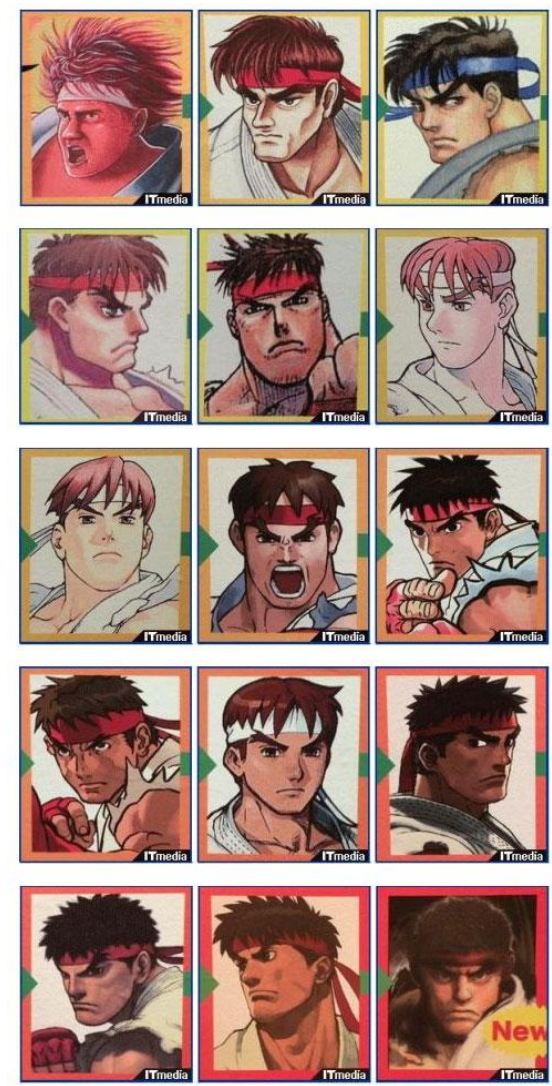

Figura 13 - Ryu, Evolução da expressão facial Fonte: Zer0Sith. Disponível em:

$<$ http://zer0sith.files.wordpress.com/2010/11/r yu_evolution.jpg?w=550>

A evolução do personagem e de todo contexto ao redor (como outros personagens, cenários, golpes especiais, sequências de animação, movimentação da câmera e outros elementos) expressa o ápice evolucionário atingido pelo jogo com o passar do tempo, quando comparamos as telas da primeira à última versão (Figura 14 e 15): 


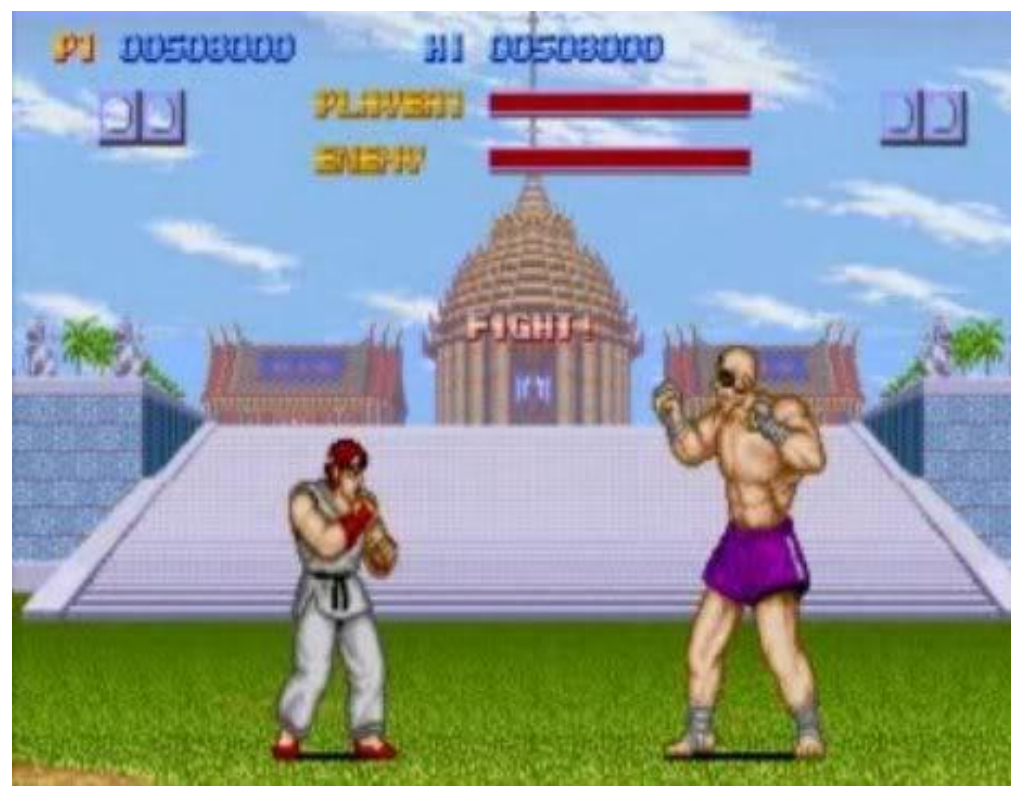

Figura 14 - Ryu contra Sagat, Street Fighter, 1987.

Fonte:Photo Bucket. Disponível em:

<http://s580.beta.photobucket.com/user/alexandre_arthur/media/streetfi ghter1.jpg.htm>

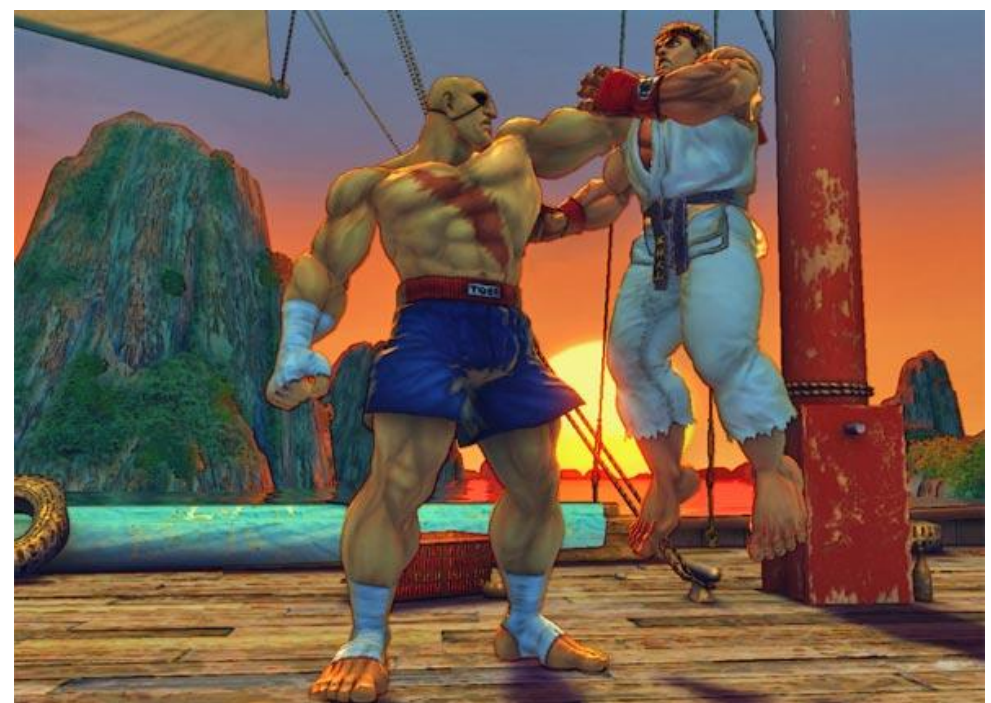

Figura 15 - Ryu contra Sagat, Super Street Fighter 4, 2010.

Fonte: G1. Disponível em:

<http://g1.globo.com/Noticias/Tecnologia/0,,MUL581401-6174,00-

PRODUTORA+CONFIRMA+STREET+FIGHTER+IV+PARA+PC + XBOX+E+PLAYSTATION.html>

Vemos nesse exercício de comparação que a mecânica do jogo é semelhante ao que fora no passado, porém os ajustes realizados em função da evolução tecnológica e da qualidade da narrativa empregadas mostram como o jogo é reinventado em seus detalhes, preservando a sua essência que permanece quase que intacta. 
Podemos assemelhar a relação do suporte da antiguidade (como arco e flecha) com o do presente (joystick). O sentido atribuído em função da perícia e das variabilidades do tempo que pudessem interferir no percurso da flecha, agora com o joystick temos expresso nas eventualidades e obstáculos programados pelo sistema.

Ao compararmos a flecha com o joystick, aparentemente não vemos relação, assim como, também, a flecha com o uma rainha preta do xadrez. Mas, ao observar o esquema sugerido por Stuart Culin (Figura 8), ao pensar nas origens do videogame, na evolução material implícita iniciada no artefato bélico e até nos games, podemos ter a seguinte imagem (Figura 16) em função das informações apresentadas neste trabalho:

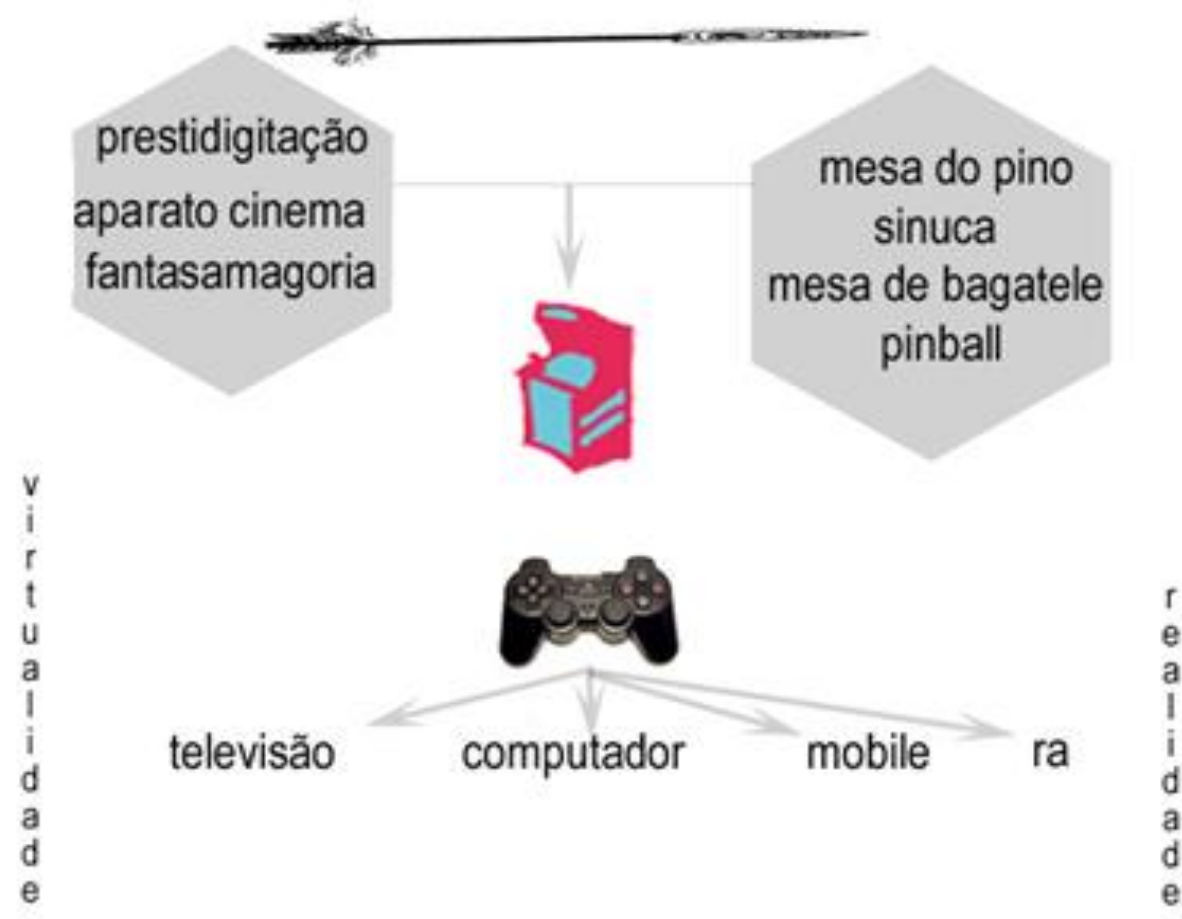

Figura 16 - Releitura da imagem Evolution of Games considerando os Videogames Fonte: Organizado pelo autor

\subsection{A temática das artes marciais no cinema e nos videogames}

A arte marcial é uma prática que se vale de cérebro e de músculos e muito mais que uma prática esportiva (BIN, 1992). Tal prática está ligada diretamente à história do homem, em atividades como guerras, caçadas e proteção de território. Tudo isso fomentou a 
necessidade de desenvolver meios que garantissem sua existência, sua cultura e as atividades associadas a seu entretenimento, como filmes e jogos.

A arte marcial possui um amplo espectro, de acordo com Wu Bin (1992), que pode ser listado como:

- Cultivo da Moral: a prática leva a cultivar bons costumes;

- Ataque e Defesa: programas de treinamentos envolvem uma série de rotinas de ataque e defesa, com mãos nuas e armas brancas; de aplicações para defesa pessoal e combate esportivo;

- Prática saudável: exercícios respiratórios e de relaxamento ajudam no fortalecimento da saúde, atuando de modo preventivo contra doenças, promovendo o equilíbrio psicológico e o fortalecimento do sistema imunológico;

- Desenvolvimento artístico: o esforço pelo contínuo aperfeiçoamento não difere de outras práticas, em que a harmonia dos movimentos necessita estar em consonância com os princípios estéticos e práticos da arte, em questões como ritmo e precisão.

- Inteligência: muito mais que um exercício físico, a arte marcial é como se fosse um exercício mental; estimula ações estratégicas e soluções imediatas que envolvem situação de pressão e combate corpo a corpo. Como uma espécie de xadrez, mas envolvendo diversos golpes por segundo e movimentos precisos, é necessário administrar situações de sucesso e de fracasso.

De acordo com Klein (2004) a sociedade da "espetacularização", afetou as artes marciais, pois, com o desenvolvido de um senso de entretenimento mundial e a necessidade de padrões narrativos que atingissem o globo com o mesmo impacto, buscou-se narrativas universais arquetípicas, capazes de dialogar com as mais diversas unidades étnicas culturais. O movimento e uma semântica "Kinesthetic" tal qual a arte marcial, preconiza e preenche esta lacuna. Nesse aspecto, traçamos um paralelo entre as narrativas corporais do cinema mudo e os primeiros jogos baseados na coordenação, pois tratam de um tipo de comunicação heurística, não dependendo de uma compreensão linguística específica, mas de algo universal. A movimentação marcial por si só é um espetáculo em que existe uma narrativa específica associada diretamente à ação, sendo os golpes uma espécie de discurso. Obviamente, isso ganha um contexto maior quando colocado dentro de um cenário, uma narrativa e um personagem. A expressão reflete a perícia e simboliza a força em relação à luta, ganhando 
proporções simbólicas e podendo ser associada ao filtro das distorções seletivas de cada um, gerando identificações e contraefetuações. As artes marciais transformaram-se em um elemento cultural ubíquo, ou seja, independente da temática, encontram-se presentes em filmes de ficção científica, de terror, de drama, de comédia, infantil e em temas que tangenciam adaptações para o videogame. Para essa autora, ocorre uma "asiatisação" de Hollywood e uma "Hollywooditização" das produtoras asiáticas de filmes. Isto se expressa tanto politicamente quanto economicamente por conta da globalização, relacionado ao eixo do Pacífico conforme podemos conferir em sua pesquisa:

\begin{abstract}
The Proliferation of martial arts in contemporary commercial Hollywood and Asia belongs to a century-long cinematic history of Trans-Pacific Borrowing and negociation. It should be seen, however, as a cultural expression of new social and economic formations that have been brought into experience by the latest phase of globalization. When you look at these displays of martial arts on our movies srcreens, we should also look trough them to the global flows of labor and capital the heightened demand for market-expanding spectacle and actions films, to the corporate strategy of glocalization, to the deeply felt need for the cinematic expressions of cultural particularity. (...) The unique properties of the martial arts film make it particularly amenable to global appreciation. (...) It is a form of local culture that is thriving under globalization, adapting to new conditions and taking on new meanings without losing all conections to its origins. (KLEIN, 2004, p. 379)
\end{abstract}

Embora a produção Asiática já existisse há muitos anos alimentando o consumismo local, foi na década de 70 que houve uma grande canalização de atenção com o surgimento de Lee Jun Fan, popularmente conhecido por Bruce Lee, que criou um gênero de retratar a luta corporal de modo minucioso que passou a ganhar escala global. Com isso uma série de outros atores (como Sonny Chiba, Jack Chan e Jet Li), estilos de luta e arquétipos de lutadores (como Ninjas, Samurais, Kick-Boxers, Monges Shaolin, e outros) ganham notoriedade no Ocidente. Através da mídia audiovisual, as artes marciais ganharam conteúdo notório, presentes em narrativas de filmes, quadrinhos e videogames. Com a homogeneização da cultura através da globalização, houve um impacto na vida cotidiana em função da moda gerada pelos filmes de Bruce Lee e a multiplicação de Dojôs pelo mundo - até então uma prática restrita a centros culturais comunitários. O herói perito em movimentos rápidos, capaz de desafiar e vencer multidões transforma-se em representante de um gênero, responsável por um novo conceito, ou seja, resgata princípios da cultura oriental ao estilo de vida ocidental. Diversas produções exemplificam essa vertente: lutadores afrodescendentes no Harlem contra uma polícia de opressão; identificação de grupos de Rap (cada um dos bairros rivais e as bandas com nomes orientais - Shaolin e Wudang Clan); músicas ao simbolismo das artes 
marciais; relação com o cotidiano. Embora estejam muito pouco no mainstream, existe uma vasta produção que agrada aos que gostam do gênero de filmes de artes marciais, sem contar as lutas corporais sempre muito presentes nas produções cinematográficas. Paralelamente às artes marciais presentes no imaginário das pessoas há pelo menos 50 anos, o gênero de games foi se desenvolvendo e se ampliando.

O primeiro jogo de luta foi o Heavywheight Champ (1976), um fliperama com controles que tinham uma empunhadura que lembrava uma luva de boxe. A visão da luta tinha um enquadramento que privilegiava a lateral do personagem na tela, como exemplificam as Figuras 17 e 18.

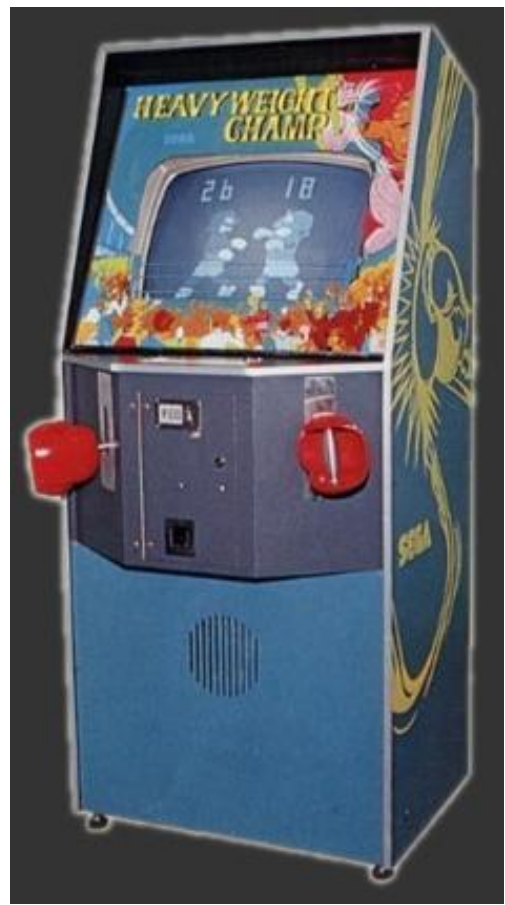

Figura 17 - Heavyweight Champ Arcade Fonte: Pink Gorilla Games. Disponível em: <http://www.pinkgorillagames.com/retro_revi ews/sega_arcade_classics.php>

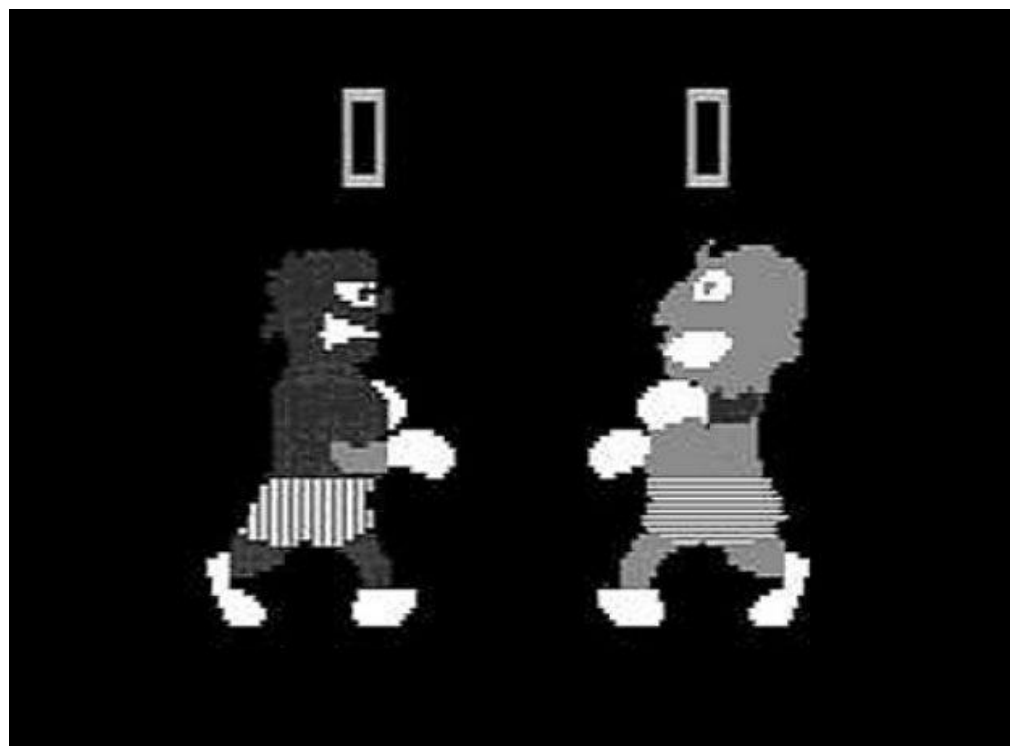

Figura 18 - Heavy Wheight Champ Gameplay Fonte: Rack DN. Disponível em: <http://17f0418678386b4e6860e4f9fcd924b589d19bf6ccc2802ea9aa.r66.cf1.rackcdn.com/6fba459df1 60ab42c76269f34ed8c83e4de12403.jpg_620x466_q85.jpg>

Ressaltamos neste jogo a sua similaridade com o Rock'em Sock'em Robots, um tipo de brinquedo e jogo da década de 60 (Figura 19), no qual os robôs eram controlados por manoplas com o objetivo de acertar a cabeça do adversário, em uma posição e em um ângulo certo, de modo a desarmá-lo e tirá-lo de combate. Ao longo dos anos, houve uma série de outras versões como Star Wars, Robocop e com personagens de Street Fighter (Figura 20). 


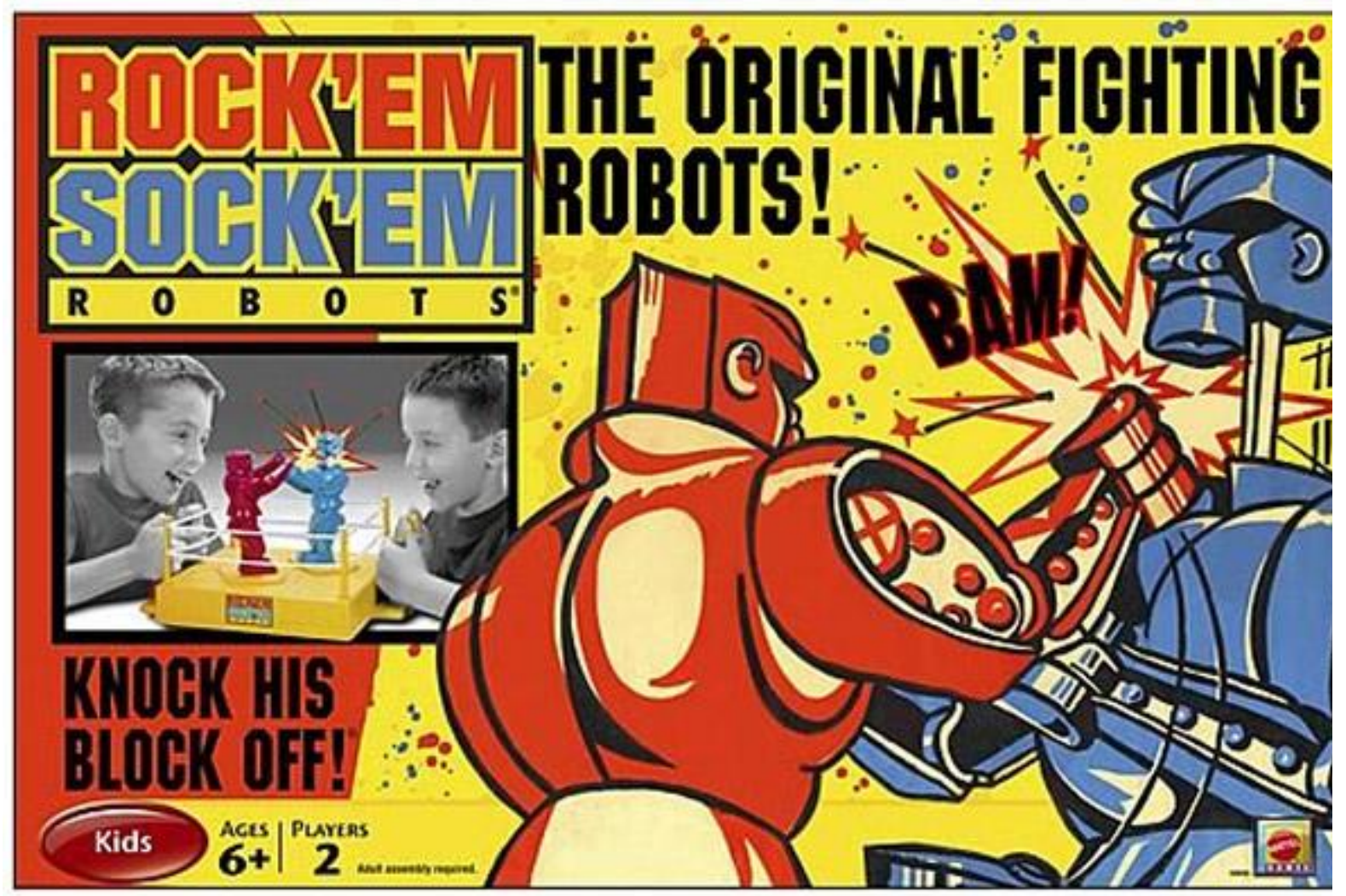

Figura 19 - Rock'em Sock'em

Fonte: Sclick. Disponível em: <http://sclick.net/cool\%20gadgets/newst-funny-gadget-gifts-toys/10/cool-latestbest-fun-toys-gadgets-gifts-for-kids-040210_rock_em_sock_em_robots_2.jpg> 


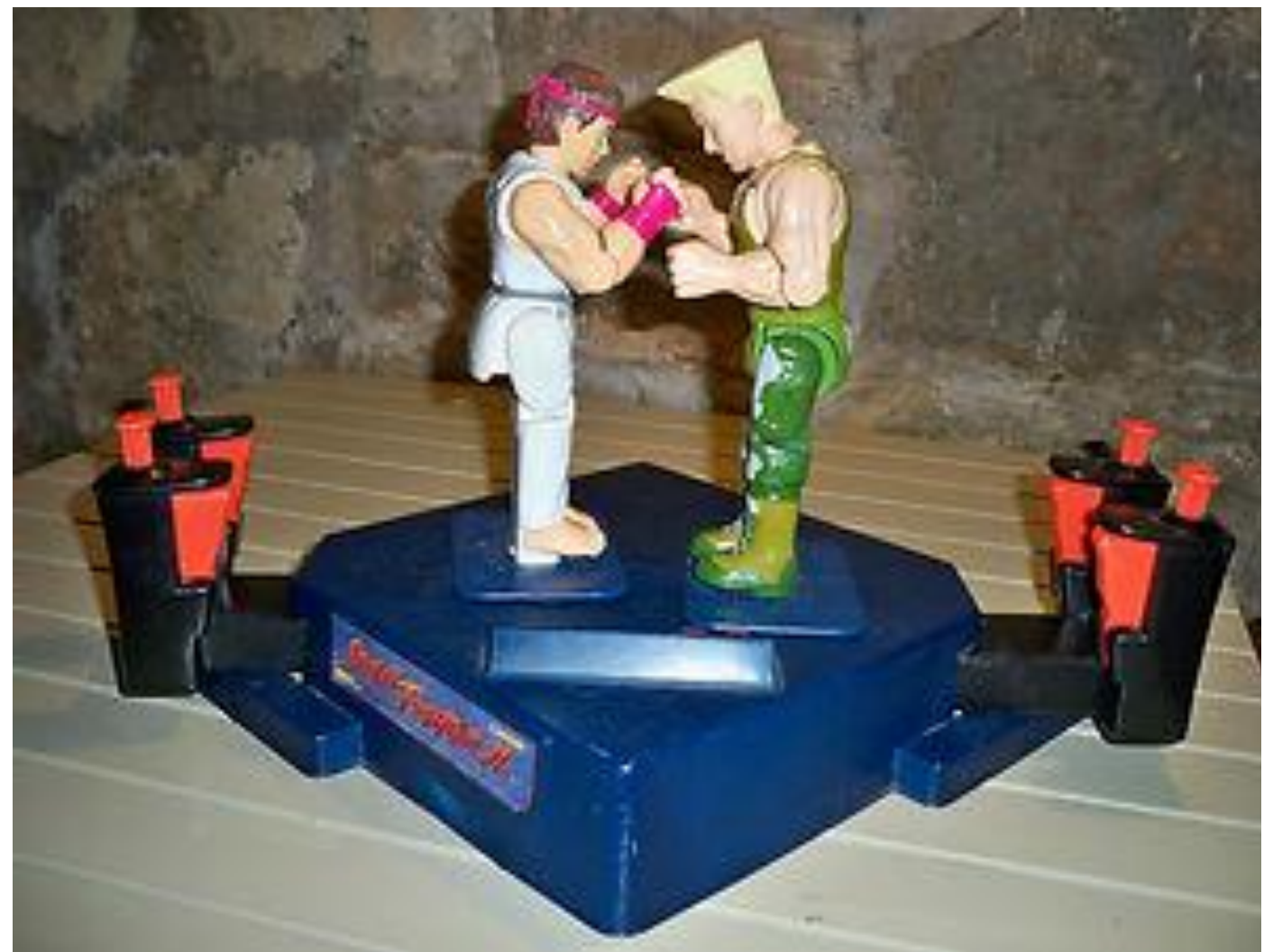

Figura 20 - Rock'em Sock'em com personagens Street Fighter

Fonte: E-Bay. Disponível em: <http://i.ebayimg.com/t/vintage-Street-Fighter-2-Rock-Em-SockEm-Video-Game-Ryu-Guile-Tiger-Capcom-1993-

/00/s/MTIwMFgxNjAw/\$(KGrHqZ,!nsE63V3Y3VvBO-7f1EoMQ 60_35.JPG>

O Game Boy Advanced, o Playstation e as plataformas móveis tiveram adaptações desses brinquedos entre os seus títulos. Esse artefato possui alto grau de popularidade, não apenas como alguma coisa que se brinca, mas como um ícone cultural, sendo aplicado em estampas de camisetas, itens decorativos e em charges de situações que envolvam algum tipo de embate, como os personagens da franquia Street Fighter (Figura 21) ou de candidatos políticos. 


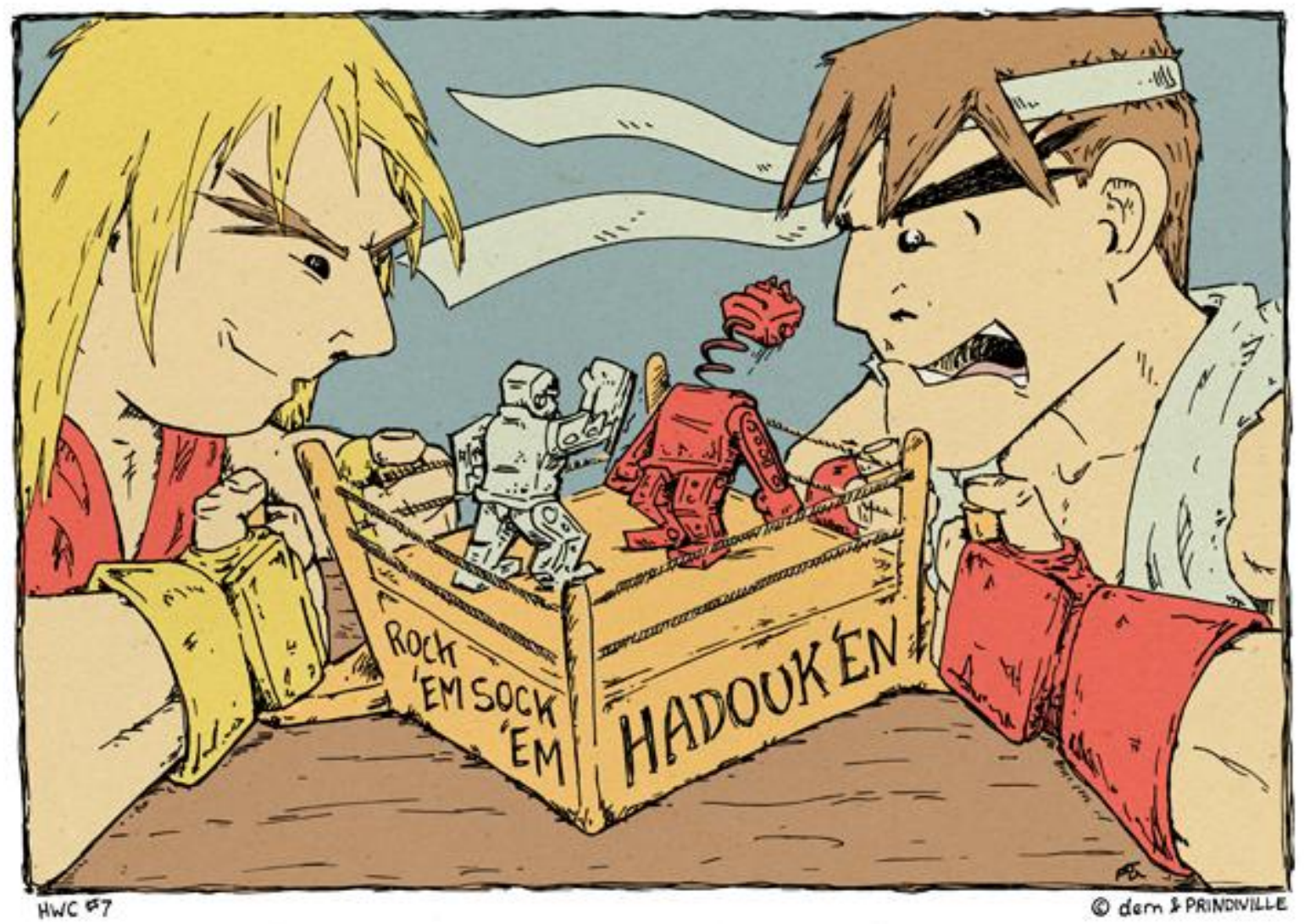

Figura 21 - Ilustração irônica sobre Rock'em Sock'em e Street Fighter

Fonte: Scallywags International. Disponível em: <http://www.dernwerks.com/HWC/comics/2009-02-16Hadouk-en.jpg>

O jogo Karatê Champ (1984) é fiel em representar a situação do dojô em relação à luta e ao visual. Diferentemente de Karateca (1984), esse jogo mantinha a câmera lateral e os jogadores ficavam parados, igual a uma arena e os golpes buscavam ser os mais fieis possíveis em relação às técnicas do Karatê (Figura 22 e 23). 


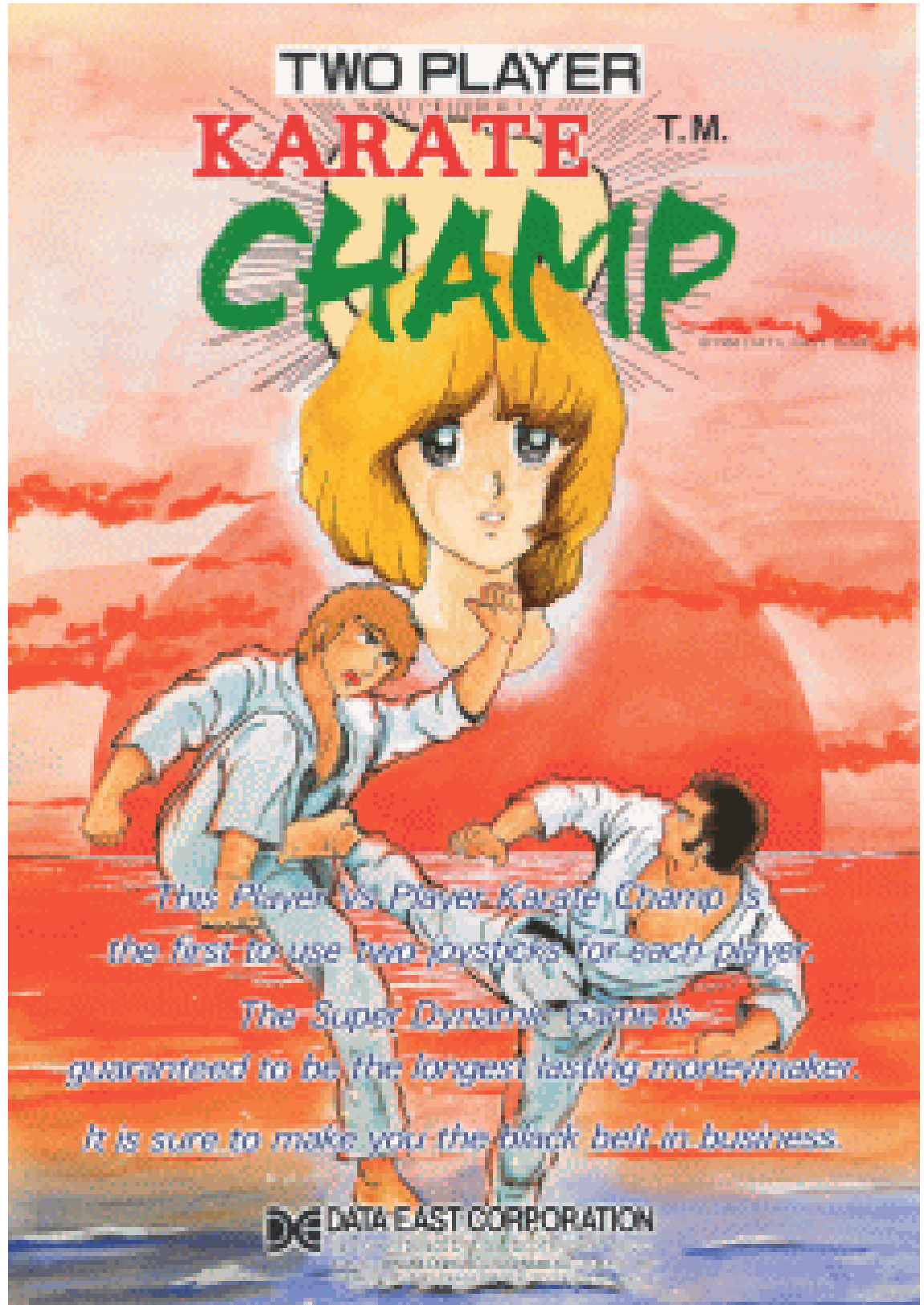

Figura 22 - Karate Champ.

Fonte: Scallywags International. Disponível em:

<http://www.dernwerks.com/HWC/comics/2009-02-16-Hadouk-en.jpg> 


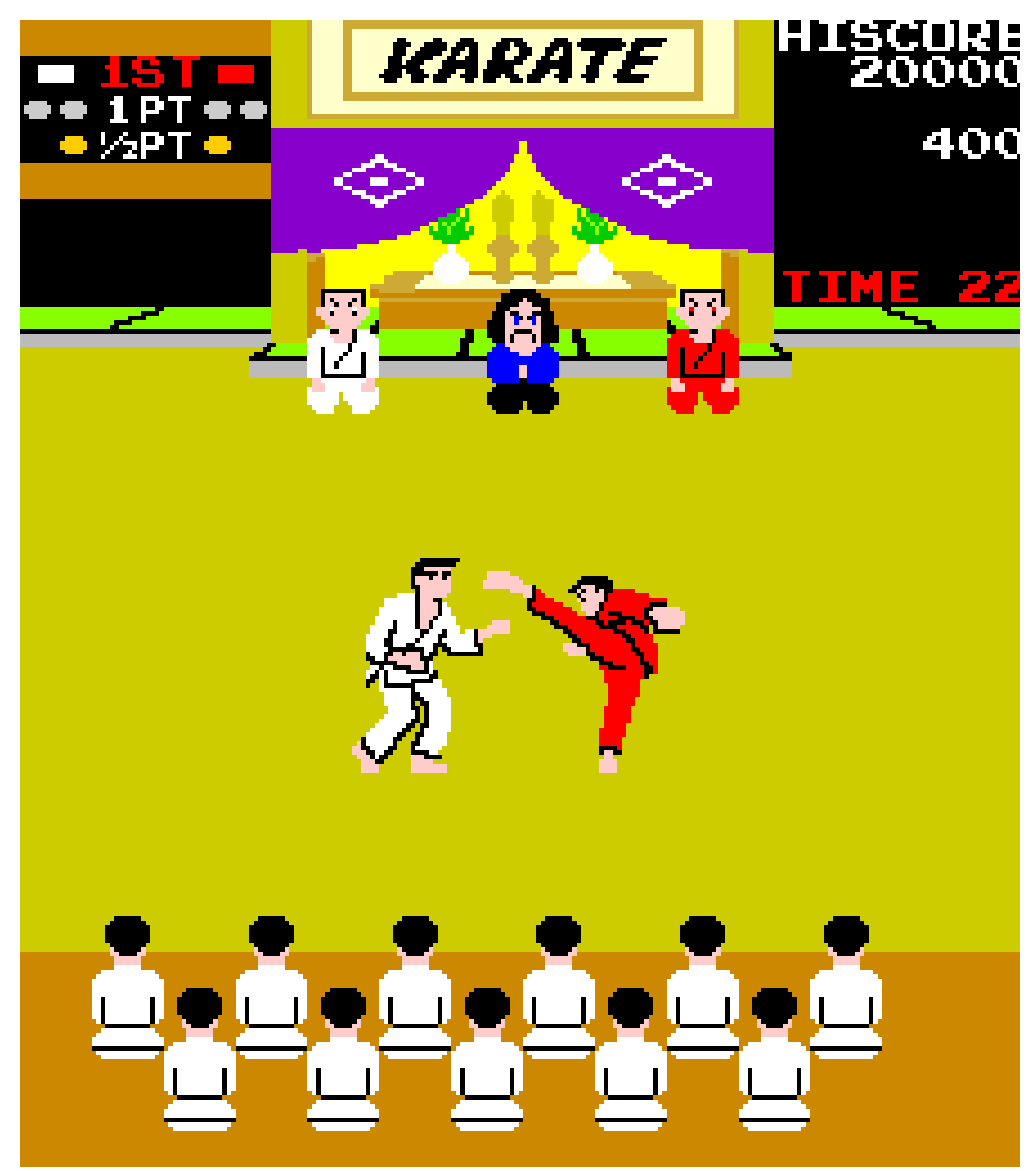

Figura 23 - Karate Champ Gameplay

Fonte: Wipedia. Disponível em:

〈http://en.wikipedia.org/wiki/File:Karate_Champ.png>

Surgido em 1984, o jogo Karateca (1984), foi realizado com a técnica de rotoscopia, primeiro filmando, depois desenhando em cima da imagem. Em 1986, o autor John Mechner, posteriormente, desenvolveu um jogo mais popular chamado Prince of Persia (1989) que representou para a época uma qualidade de movimentação, inércia corporal e cênica de muita qualidade. O jogo Karateca continha em si elementos dos três tipos de jogos associados às artes marciais: beat'em up's, esportes de combate e os fighting games. Apesar de andar por uma plataforma contínua nos primeiros adversários, o jogo permitia uma mobilidade para ganhar e perder espaço e, na medida em que avançava, travava a cena apresentando uma câmera fixa igual aos fighting games (Figura 24). 


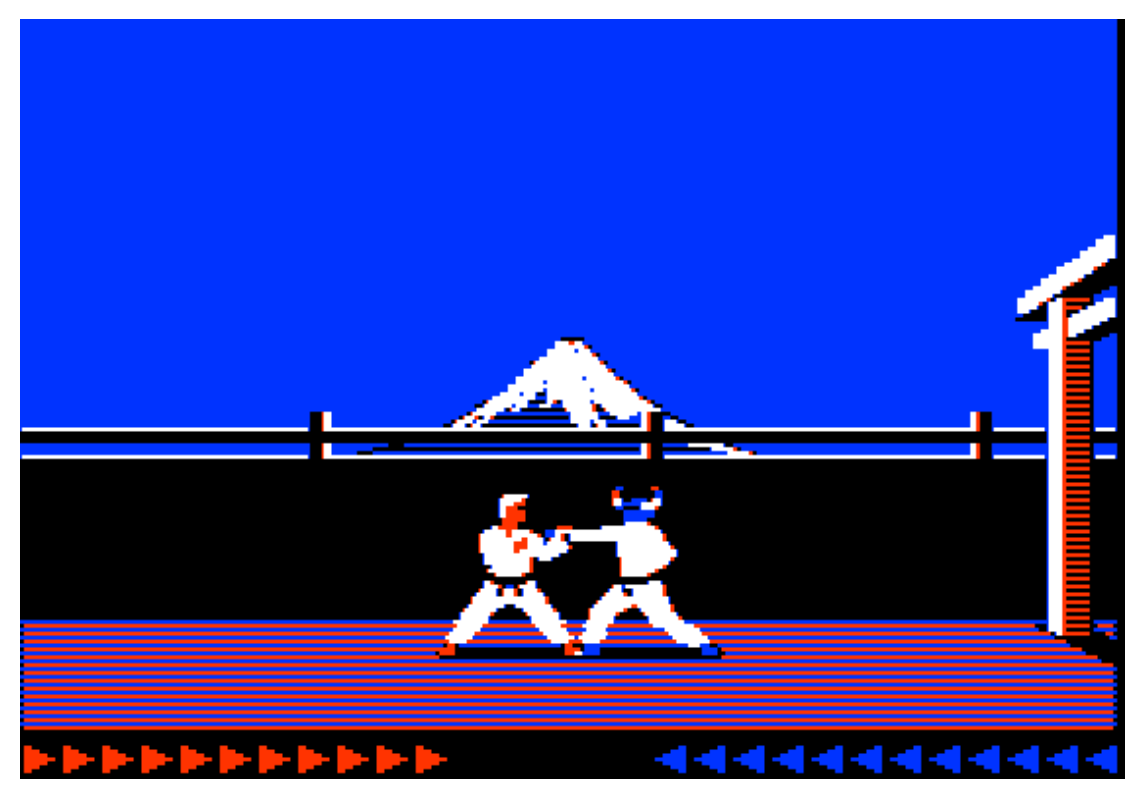

Figura 24 - Karateca Gameplay

Fonte: Hardcore Gamer. Disponível em: <http://www.hardcoregamer.com/wpcontent/uploads/2012/10/karateka.png>

Posteriormente, surgiu o Yie-Ar Kung Fu (1985), considerado por muitos escritores de leitura especializada como a maior influência dos jogos de luta (Figura 25).

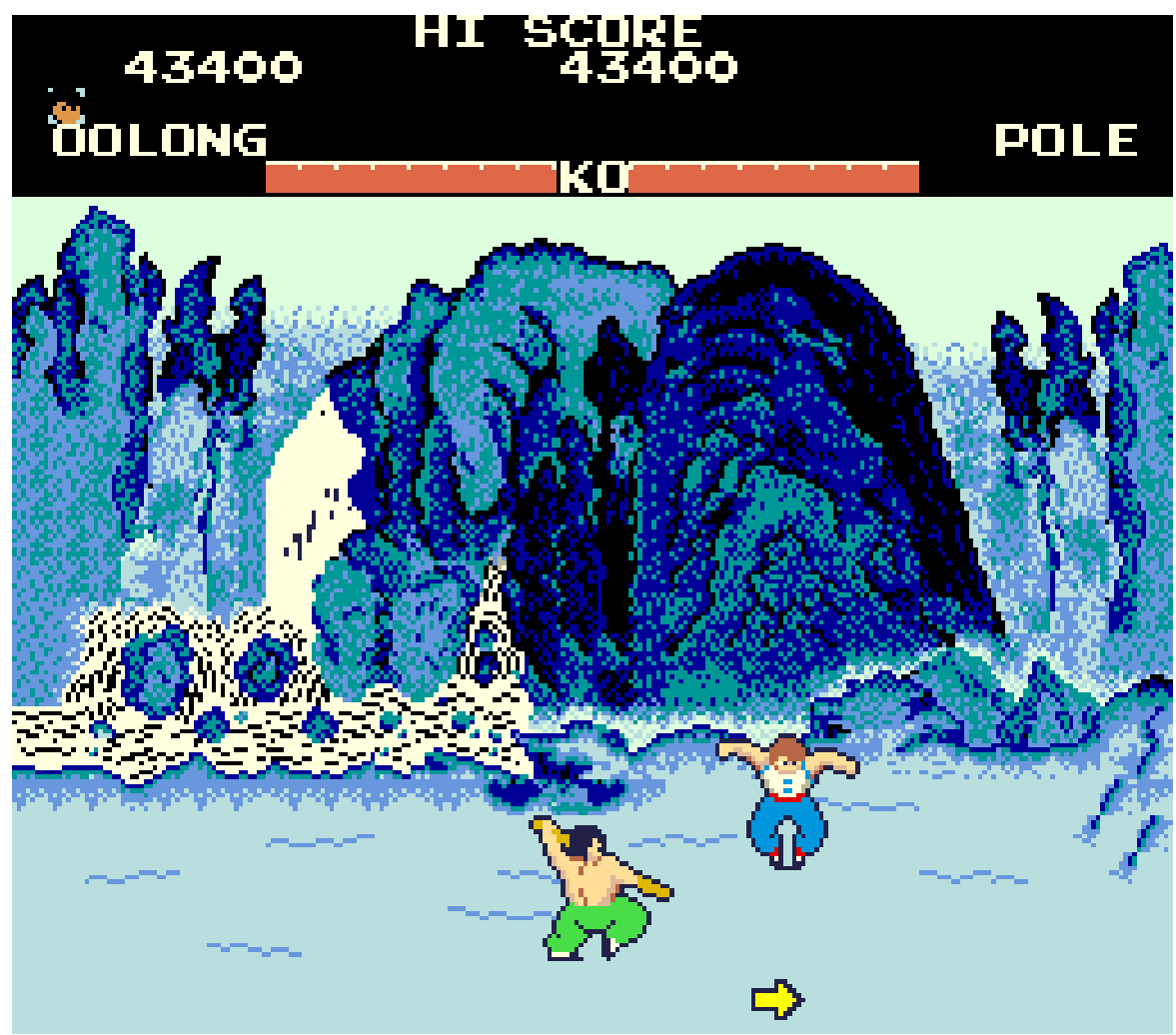

Figura 25 - Ye-Ar Kung Fu Gameplay

Fonte: Arcade Museum. Disponível em: <http://www.arcademuseum.com/images/118/1181242188152.png> 
Após os outros títulos apresentados, diversos itens foram colocados e aprimorados no jogo, em relação à mecânica e em detalhes narrativos que os jogos da atualidade exploram (como informações organizadas na tela; personagens que ganharam identidade, nome, histórico; detalhes como roupas, cabelos e movimentação própria). No caso, o herói do jogo Oolong é uma referência direta a Bruce Lee e de outros vilões que fazem referências a atores de filmes de luta. Outro aspecto digno de nota é em relação à trilha sonora, que varia de acordo com a vida dos personagens. À medida que a barra de vida se aproxima do fim, a trilha sonora se intensifica.

Há ainda uma grande quantidade de jogos de luta, como os de fighting games, beat 'em 'ups e os esportivos, porém, nos ativemos aos citados como as bases precursoras dos modelos atuais, inclusive que influenciaram o objeto de estudo. Conforme podemos ver na Figura 26, a permanência dos jogos de luta, por mais que represente um campo pequeno no gráfico, se comparado a outros gêneros mais populares, associa-se diretamente ao público simpatizante dessa temática e certamente, configura-se tal índice perante a representatividade de alguns títulos populares (Street Fighter, Mortal Kombat e Tekken) e spin-offs, crossovers ou franquias que envolvam diferentes títulos, estúdios e até personagens como os heróis da Marvel e da DC.

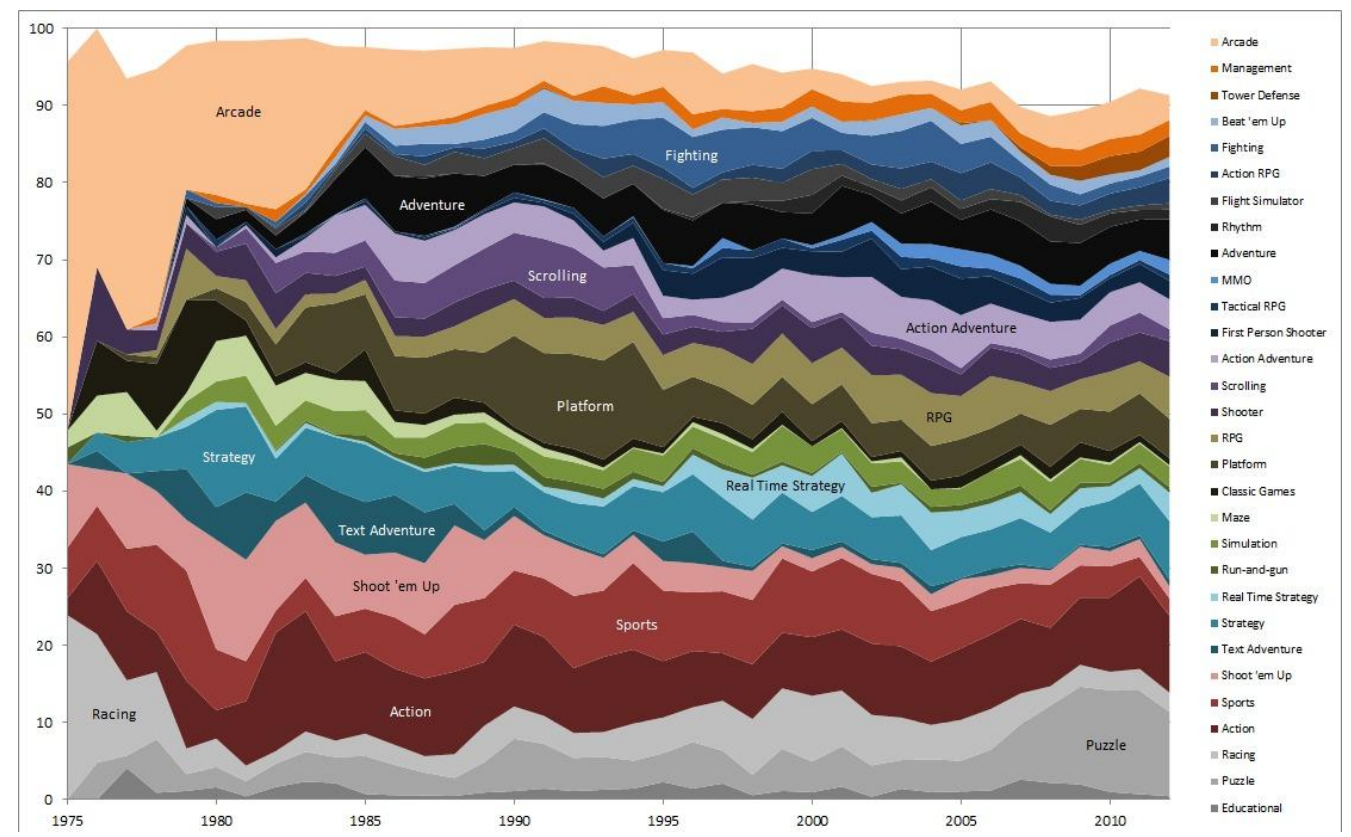

Figura 26 - Percentages of genre and plataform releases since 1975

Fonte: Reddit. Disponível em:

<http://www.reddit.com/r/gaming/comments/1319ad/recently_i_scraped_a_database_of_24000_videogames/> 
Considerando a matriz audiovisual cinética dos filmes e a cinética interativa dos jogos, no momento em que os duelos fílmicos são representados e permitem apenas uma projeção da própria imaginação de como seria se o telespectador estivesse no local do personagem, os games representam um duelo no estrito senso, pois, ou se tem a perícia e a habilidade necessária, ou se perde o desafio. Caso haja o interesse de vencer, joga-se novamente tantas vezes quantas forem necessárias.

Os jogos de luta baseiam-se nos clichês de filmes de luta, combinando o cenário propício, um objetivo condutor e situações que permitam resolver os conflitos. Com essa influência direta, algumas franquias de jogos de luta são cópias de Bruce Lee, idênticas (Figura 27) tanto nos trejeitos quanto na aparência, da mesma forma que os cenários são desde arenas até rodas de pessoas que acompanham a luta e templos no oriente. Outros atores também inspiraram outros personagens (como Jean Claude Van Dame e Steven Segal).

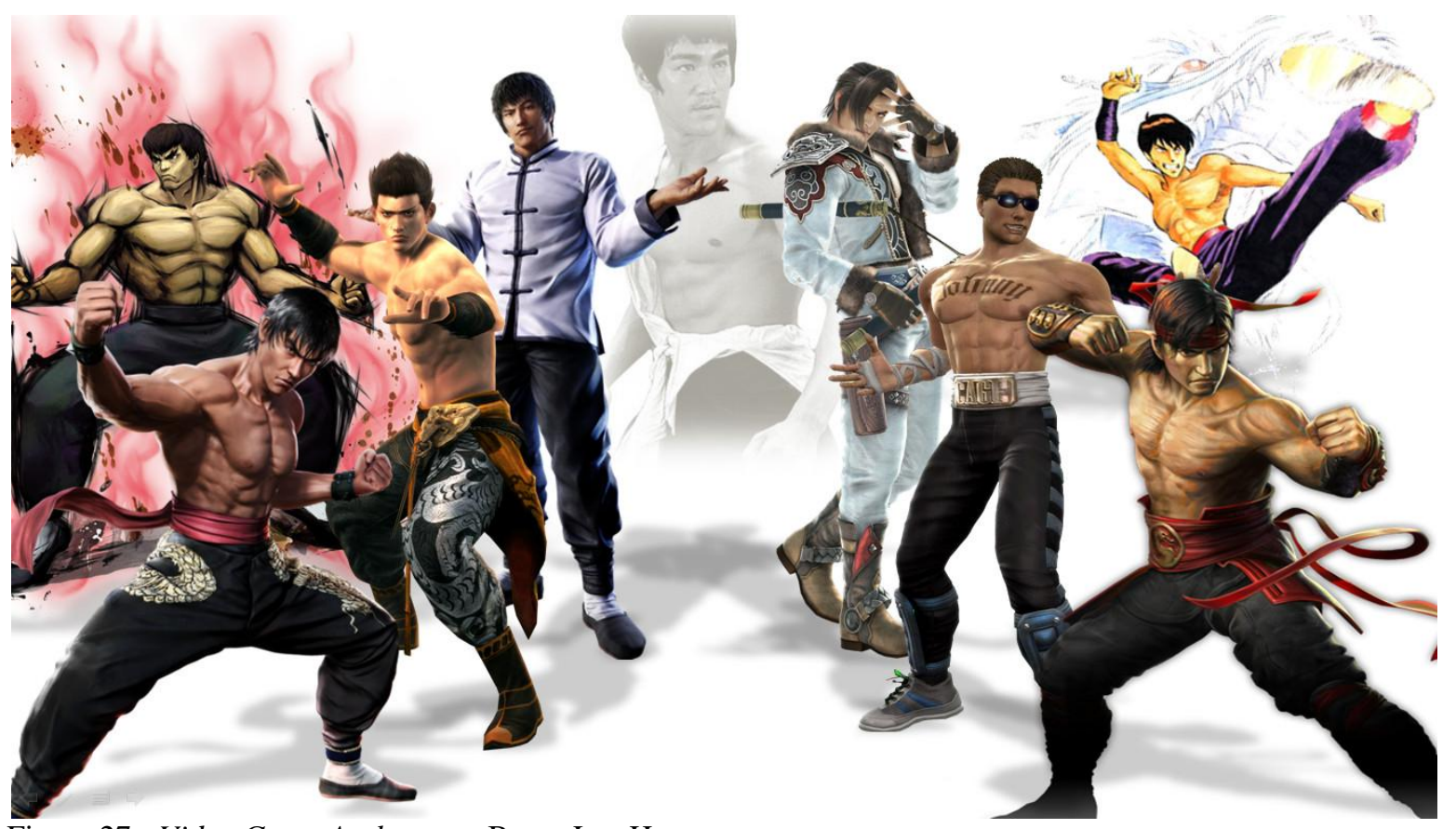

Figura 27 - Video Game Archetypes: Bruce Lee Homages.

Fonte: Deviant Art. Disponível em: <http://the4thsnake.deviantart.com/art/Video-Game-Archetypes-BruceLee-Homages-261488268>

Um aspecto da linguagem audiovisual evolutiva dos games, com o auxílio da tecnologia associado à criatividade e às novas versões de jogos de luta, utiliza a capacidade de seus processadores para gerar efeitos que amplifiquem a experiência de modo singular. No Mortal Kombat 9 (2011), ao acionar poderes especiais, a modelagem e seus diversos níveis de 
informação permitem contemplar de forma bem detalhada músculos, veias e órgãos, semelhante como demonstrado no documentário A Ciência das Artes Marciais (2011). Em Super Street Fighter 4 (2010), a modelagem em três dimensões permite a viagem da câmera em um amplo aspecto de algumas manobras, simulando como seria o combate em tempo real indo além da capacidade de um filme, estabelecendo uma vivência da cena em ângulos que uma câmera normal dificilmente captaria e criando um grau de experiência exponencial à própria realidade. 


\section{Pesquisa em Videogame}

\subsection{Tipo de pesquisa}

O método de abordagem desta pesquisa seguiu os padrões hipotético-dedutivos, partiu de linhas de análise pré-estabelecidas em cada uma das áreas citadas (videogame e linguagem audiovisual) para suprir uma lacuna identificada perante o que ocorre entre o universo prático e o teórico. Por conseguinte, a análise proposta visou testar a conjectura frente ao alcance do fenômeno apontado, conforme preconiza Popper (1993). O principal embasamento teórico buscou um modo de abordagem voltado para o dinamismo estético presente na relação da interação entre o usuário e o conteúdo audiovisual associado aos jogos. A fluidez entre tema e objeto precisa transcender a pesquisa em sua forma estanque para contemplar os processos analisados de maneira fluída e sujeita a mudanças e transformações que possam surgir da análise em si. Esse pensamento seguiu a linha metapórica conforme descreve Marcondes (2010). Uma vez que o objeto de pesquisa e sua destinação estão associados diretamente com questões menos exatas e mais estéticas que envolvem a fruição dos sentidos, utilizamos a lógica hipotético-dedutiva e a lógica metapórica. Entende-se a abordagem hipotético-dedutiva dividida em duas partes:

- indutiva - associada à compilação de material para embasar o estudo;

- dedutiva - ligada à questão da formulação propositiva de abordagem, perante aquilo que precisa ser esclarecido de modo a obter uma resposta generalizada sobre o tema.

O procedimento da análise foi em sua grande parte comparativo, abordando as três linhas de análise e em menor grau sistêmico, buscando estruturar os resultados, não apenas associados à questão da análise e seus resultados, mas também, perante a questões de representações gráficas.

Nas formas de abordagem utilizada existe um estágio (ao final da pesquisa) que se refere ao falseamento, porém, essa terminologia se aplica melhor às ciências exatas. Com isso, de um lado temos um rigor analítico científico e, de outro, uma abordagem que permite certa liberdade de análise e de manipulação do objeto de pesquisa, indo diretamente ao que fora proposto por Gadamer (1997). 


\subsection{Objeto de Estudo}

A proposta de estudar um jogo de luta, como o Super Street Fighter IV (2010), motivou a relação simbólica da interface que se estabelece entre o jogador e a máquina, como um Dojô. Este jogo pertence à categoria de jogos chamados de Fighting Games, que por sua vez estão dentro de um grupo chamado Action Games. Estes são caracterizados por exigirem do jogador, reflexos rápidos, considerando precisão, tempo de reação e capacidade de decisão rápida. Outros jogos nesta categoria são (Beat'm Up, Shoot em Up, Fps, Tps, Hack and Slash). Nos Fighting Games, os jogadores controlam personagens na tela como se fosse uma arena. Para os personagens que se enfrentam, seja jogador contra jogador, seja jogador contra máquina, existe um equilíbrio de forças, de poder e de energias, em que aquele que demonstrar maior habilidade vence o round $^{7}$.

Ressaltamos também a questão da câmera e o cenário, uma vez que o espaço é prédefinido e o enquadramento é sempre o mesmo, delimitando o que seria um ringue. Obviamente que, com o avanço da tecnologia, há uma série de efeitos que acontecem no cenário, porém, mesmo havendo mudança de ringue, tão logo a sequência de transição ocorra, volta-se para a tela.

Outros gêneros associados às lutas que, apesar de uma aparente semelhança com jogos de confronto corporal e que se comparadas apresentam diferenças bem evidentes, são: Beat'em Up e os Sport Games. Basicamente, as diferenças dos Fighting Games com a Beat'em Up é que, neste, os personagens controlados pelos jogadores sempre enfrentam personagens controlados pela máquina. Neles, o nível de habilidade do NPC (non playable character) é inferior e a ação se dá através do deslocamento da câmera pela tela (side scroll) com o surgimento constante de inimigos. Jogos de esportes (como o Boxe, Artes Marciais e $M M A$ ), por apresentarem uma maior identidade com a realidade, colocam itens básicos mais reais (como proporção corporal, ausência de poderes, presença de juiz e regras oficiais) e a presença de anúncios publicitários.

\footnotetext{
${ }^{7}$ UNIVESITY OF MELBOURNE - Genre and game studies. Disponível em: <http://www.academia.edu/385966/Genre_and_Game_Studies_Toward_a_Critical_Approach_to_Video_Game_ Genres>. Acesso em 17 de ago de 2012.

WASHINGTON STATE UNIVERSITY - A Taxonomy of Computer Games. Disponível em: <https://sakai.rutgers.edu/access/content/group/af43d59b-528f-42d0-b8e5-

70af85c439dc/reading/crawford_1982.pdf >. Acesso em 1 de setembro de 2012.
} 
O título Super Street Fighter IV tem grande representatividade no mercado, é uma das franquias mais populares e de expressiva penetração na sociedade. Considerada a $30^{a}$ franquia mais lucrativa da história, vendeu mais de 30 milhões de cópias e lucrou com a marca mais de 1 bilhão de dólares em seus 25 anos de existência ${ }^{8}$.

Tabela 3 - Ranking de Franquias de Jogos de Luta 1981-2013

\begin{tabular}{|c|c|c|l|l|c|}
\hline Franquia & Ranking & $\begin{array}{l}\text { Quantidade de } \\
\text { cópias vendidas } \\
\text { (mi) }\end{array}$ & $\begin{array}{l}\text { Estilo de } \\
\text { jogo }\end{array}$ & $\begin{array}{l}\text { Primeiro } \\
\text { lançamento }\end{array}$ & $\begin{array}{l}\text { Quantidad } \\
\text { e de títulos }\end{array}$ \\
\hline WWE Smack Down vs. Raw & 25 & 47 & Esportes, Luta & 2000 & 27 \\
\hline Tekken & 29 & 41.4 & Fight & 1994 & 10 \\
\hline Street Fighter & 38 & 33 & Fight & 1987 & 38 \\
\hline Mortal Kombat & 49 & 26 & Fight & 1992 & 15 \\
\hline Super Smash Bros & 53 & 22.78 & Fight & 1999 & 4 \\
\hline Dynasty Warriors & 76 & 18 & Beat'em Up & 1997 & 8 \\
\hline Project Soul Calibur & 95 & 13.38 & Fight & 1995 & 8 \\
\hline Naruto: Ultimate Ninja & 131 & 10 & Fight & 2003 & 12 \\
\hline Dead or Alive & 133 & 7.95 & Fight & 1996 & 12 \\
\hline
\end{tabular}

Fonte: List of best selling vídeo game franchises. Wikipédia. Organizado pelo autor.

Embora extremamente popular, não é o primeiro jogo de luta no ranking das franquias mais lucrativas. O jogo WWE Smack Down vs. Raw (2000) é referente ao programa de televisão de luta livre, conhecido por telecatch, em que o ringue é um palco para lutadores mascarados e performáticos que interpretam lutas caricaturizadas e segue um roteiro prévio, definindo claramente quem são os heróis e os vilões. Trata-se de um programa que há décadas é transmitido no mundo inteiro, de estilo bem característico e que faz parte de um recorte cultural. Já a franquia Tekken, embora não tenha personagens tão populares quanto a franquia Street Fighter, é um jogo que trabalha muito expressivamente a questão 3D, utilizando-se da posição da câmera de modo fluido, conseguindo bons resultados de imagem. Outro aspecto digno de nota é que a movimentação, inclusive nas manobras mais complexas para se conseguir criar uma estratégia, é relativamente fácil de ser realizada pelo jogador. O efeito dessa jogabilidade na tela é diretamente proporcional ao resultado nela expresso, ou seja, no Street Fighter realizar movimentos especiais se traduz por comandos complexos que devem

${ }^{8}$ Disponível em: <http://en.wikipedia.org/wiki/List_of_best-selling_video_game_franchises/>. Acesso em: fev. 2012. 
ser dominados, já no Tekken, qualquer botão e direção gera algo especial, sendo assim mais fácil de jogar e representando audiovisualmente algo mais rico.

A franquia Street Fighter possui sete jogos principais (Street Fighter, 1989; Street Fighter I, 199I; Street Fighter III, 1997; Street Fighter Alpha, 1995; Street Fighter IV, 2010; dois spin-offs, o Street Fighter Movie, 1995 e o Street Fighter 2010, 1990 - produzido na década de 90 para o NES) e outros títulos e crossovers. Dos primeiros cinco jogos descritos, inseridos na cronologia oficial, existem diversas versões para cada uma das edições mencionadas. Com exceção do Street Fighter 1, todos os outros tiveram mais de uma versão, com mudança de personagens, plataformas e mesmo da velocidade da inteligência artificial. Existem outros jogos que envolvem a marca Street Fighter:

- os crossovers - jogos que misturam personagens de diferentes franquias, tais como os da Marvel, outros personagens da Capcom, SNK, Namco, etc., num total de dezoito jogos;

- os três jogos realizados por outras empresas além da Capcom, porém, o Street Fighter EX (1996) tem 6 versões.

Tabela 4 - Jogos da Franquia Street Figther 1987-2013

\begin{tabular}{|c|c|c|c|c|}
\hline Título & $\begin{array}{l}\text { Ano } \\
\text { lanç. }\end{array}$ & $\begin{array}{l}\text { Qtde. } \\
\text { person. }\end{array}$ & Console & Estilo \\
\hline Street Fighter & 1987 & 12 & $\begin{array}{l}\text { Arcade, TurboGrafx-CD, PC, Amstrad CPC, ZX Spectrum, } \\
\text { Commodore 64, Amiga Virtual Console, Xbox, PlayStation } \\
\text { 2, PlayStation Portable }\end{array}$ & Fight \\
\hline $\begin{array}{l}\text { Street Fighter II: The World } \\
\text { Warrior }\end{array}$ & 1991 & 12 & $\begin{array}{l}\text { Arcade, Super NES, Mega Drive/Genesis, Master System, } \\
\text { Amiga, Atari ST, Commodore 64, ZX Spectrum, PC, Game } \\
\text { Boy, PlayStation, Sega Saturn, PlayStation Portable, iOS, } \\
\text { PlayStation 2, Xbox, Java ME, Virtual Console (Wii) }\end{array}$ & Fight \\
\hline $\begin{array}{l}\text { Street Fighter II': Champion } \\
\text { Edition }\end{array}$ & 1992 & 12 & $\begin{array}{l}\text { Arcade, PC Engine, Sharp X68000, Master System, Mega } \\
\text { Drive/Genesis, SNES, Playstation, Sega Saturn, Playstation } \\
\text { 2, Xbox, Playstation Portable }\end{array}$ & Fight \\
\hline $\begin{array}{l}\text { Street Fighter II: Hyper } \\
\text { Fighting }\end{array}$ & 1993 & 12 & $\begin{array}{l}\text { Arcade, Super NES, Mega Drive/Genesis, Sega Saturn, } \\
\text { PlayStation, Playstation 2, Xbox, Playstation Portable, Xbox } \\
360\end{array}$ & Fight \\
\hline Super Street Fighter II & 1993 & 16 & $\begin{array}{l}\text { Arcade, Amiga, FM-Towns PC-DOS, Sharp X68000, } \\
\text { PlayStation, Sega Saturn, Mega Drive/Genesis, SNES, } \\
\text { Virtual Console }\end{array}$ & Fight \\
\hline Street Fighter - Fight Arcade & 1994 & 17 & $\begin{array}{l}\text { Arcade, Amiga. PC-DOS, 3DO, Dreamcast, Game Boy } \\
\text { Advance, PlayStation, Sega Saturn }\end{array}$ & Fight \\
\hline Hyper Street Fighter II & 2003 & 17 & Arcade, PlayStation 2, Xbox & Fight \\
\hline $\begin{array}{l}\text { Super Street Fighter II Turbo } \\
\text { HD Remix }\end{array}$ & 2008 & 17 & PlayStation Network, Xbox Live Arcade & Fight \\
\hline $\begin{array}{l}\text { Street Fighter Alpha: Warriors' } \\
\text { Dreams }\end{array}$ & 1995 & 13 & $\begin{array}{l}\text { Arcade, Game Boy Color , PlayStation, PlayStation 2, Sega, } \\
\text { Saturn, Windows, CPS Changer, }\end{array}$ & Fight \\
\hline $\begin{array}{l}\text { Street Fighter Alpha } 2 \text { Super } \\
\text { Street Fighter II Turbo }\end{array}$ & 1996 & 18 & $\begin{array}{l}\text { Arcade, PlayStation, PlayStation 2, Sega Saturn, SNES, } \\
\text { Windows, PlayStation Network, Virtual Console }\end{array}$ & Fight \\
\hline Street Fighter Alpha 3 & 1998 & 28 & $\begin{array}{l}\text { Arcade, Sega Dreamcast, Game Boy Advance, PlayStation, } \\
\text { PocketStation, PlayStation 2, PlayStation Portable, Sega } \\
\text { Saturn (Japan only) }\end{array}$ & Fight \\
\hline Street Fighter EX & 1996 & 17 & Arcade, PlayStation, PlayStation Network & Fight \\
\hline Street Fighter EX2 & 1998 & 19 & Arcade, PlayStation & Fight \\
\hline Street Fighter EX3 & 2001 & 28 & PlayStation 2 & \\
\hline
\end{tabular}




\begin{tabular}{|c|c|c|c|c|}
\hline Título & $\begin{array}{l}\text { Ano } \\
\text { lanç. }\end{array}$ & $\begin{array}{c}\text { Qtde. } \\
\text { person. }\end{array}$ & Console & Estilo \\
\hline Fight $X$-Men vs. Street Fighter & 1996 & 19 & Arcade, Sega Saturn (Japan-only), PlayStation & Fight \\
\hline $\begin{array}{l}\text { Marvel Super Heroes vs. Street } \\
\text { Fighter }\end{array}$ & 1997 & 26 & Arcade, Sega Saturn (Japan-only), PlayStation & Fight \\
\hline $\begin{array}{l}\text { Marvel vs. Capcom: Clash of } \\
\text { Super Heroes }\end{array}$ & 1998 & 22 & $\begin{array}{l}\text { Arcade, Dreamcast, PlayStation, Xbox Live Arcade, } \\
\text { PlayStation Network }\end{array}$ & Fight \\
\hline $\begin{array}{l}\text { Marvel vs. Capcom 2: New } \\
\text { Age of Heroes }\end{array}$ & 2000 & 56 & PlayStation 3, Xbox 360 & Fight \\
\hline $\begin{array}{l}\text { Marvel vs. Capcom 3: Fate of } \\
\text { Two Worlds }\end{array}$ & 2011 & 38 & PlayStation 3, Xbox 360 & Fight \\
\hline Marvel vs. Capcom Origins & 2012 & 21 & PlayStation 3, Xbox 360 & Fight \\
\hline $\begin{array}{l}\text { Marvel vs. Capcom 3: Fate of } \\
\text { Two Worlds }\end{array}$ & 2011 & 50 & PlayStation 3, Xbox 360, Playstation Vita & Fight \\
\hline $\begin{array}{l}\text { Street Fighter III: New } \\
\text { Generation }\end{array}$ & 1997 & 12 & Arcade, Dreamcast & Fight \\
\hline $\begin{array}{l}\text { Street Fighter III 2nd Impact: } \\
\text { Giant Attack } 1997\end{array}$ & 1997 & 15 & Arcade, Dreamcast & Fight \\
\hline $\begin{array}{l}\text { Street Fighter III 3rd Strike: } \\
\text { Fight for the Future }\end{array}$ & 1999 & 20 & $\begin{array}{l}\text { Arcade, Dreamcast, PlayStation 2, Xbox, PlayStation 3, } \\
\text { Xbox } 360\end{array}$ & Fight \\
\hline Street Fighter IV & 2008 & 19 & Arcade, PlayStation 3, Xbox 360, Microsoft Windows, iOS & Fight \\
\hline $\begin{array}{l}\text { Super Street Fighter IV: 3D } \\
\text { Edition }\end{array}$ & 2011 & 19 & Nintendo 3DS & Fight \\
\hline Street Fighter II - The Movie & 1995 & 14 & Arcade, PlayStation, Sega Saturn & Fight \\
\hline $\begin{array}{l}\text { Street Fighter 2010: The Final } \\
\text { Fight }\end{array}$ & 1990 & 1 & Nintendo & $\begin{array}{l}\text { Platafor } \\
\text { ma }\end{array}$ \\
\hline Street Fighter X Tekken & 2012 & 55 & Arcade, PlayStation 3, Xbox 360, PS Vita, PC e iOS & Fight \\
\hline $\begin{array}{l}\text { SNK vs. Capcom: The Match of } \\
\text { the Millennium }\end{array}$ & 1999 & 26 & Neo Geo Pocket Color & Fight \\
\hline SVC Chaos: SNK vs. Capc & 2003 & 36 & Arcade, PlayStation 2, Xbox & Fight \\
\hline $\begin{array}{l}\text { Tatsunoko vs. Capcom: Cross } \\
\text { Generation of Heroes }\end{array}$ & 2008 & 28 & Arcade e Wii & Fight \\
\hline Namco $\times$ Capcom & 2005 & 2 & PlayStation 2 & $\begin{array}{l}\text { RPG de } \\
\text { ação e } \\
\text { Tático }\end{array}$ \\
\hline Street Fighter x Mega Man & 2012 & 17 & $\mathrm{PC}$ & $\begin{array}{l}\text { Platafor } \\
\text { ma }\end{array}$ \\
\hline Project X Zone & 2012 & 226 & Nintendo 3DS & $\begin{array}{l}\text { RPG } \\
\text { Tático }\end{array}$ \\
\hline $\begin{array}{l}\text { Street Fighter Online: } \text { Mouse } \\
\text { Generation }\end{array}$ & 2009 & 19 & $\mathrm{PC}$ & Fight \\
\hline Super Puzzle Fighter II Turbo & 1996 & 13 & $\begin{array}{l}\text { Arcade, PlayStation, Sega Saturn, Game Boy Advanced, } \\
\text { PSP,Xbox Live Arcade \& PlayStation Network }\end{array}$ & Puzzle \\
\hline Cannon Spike & 2000 & 7 & Arcade, Dreamcast & $\begin{array}{l}\text { Multi- } \\
\text { directio } \\
\text { nal } \\
\text { Shoorte } \\
\text { r }\end{array}$ \\
\hline
\end{tabular}

Fonte: STREET Fighter. Wikipedia. Disponível em: 〈http://pt.wikipedia.org/wiki/Street_Fighter〉. Acesso em: dez. 2012

Registra-se no mercado uma série de outros produtos (que necessariamente não são licenciados) para a cultura Fandom, aquela na qual o fã recria de acordo com a sua interpretação, projetando seus valores (JENKINS, 2008). Há inúmeras produções na internet, 
como desenhos rebuscados, street art, toy art, e desenhos temáticos, que sequer se aproximam da realidade dos personagens, como é o caso das versões zumbis e medievais, conforme podemos ver alguns exemplos:

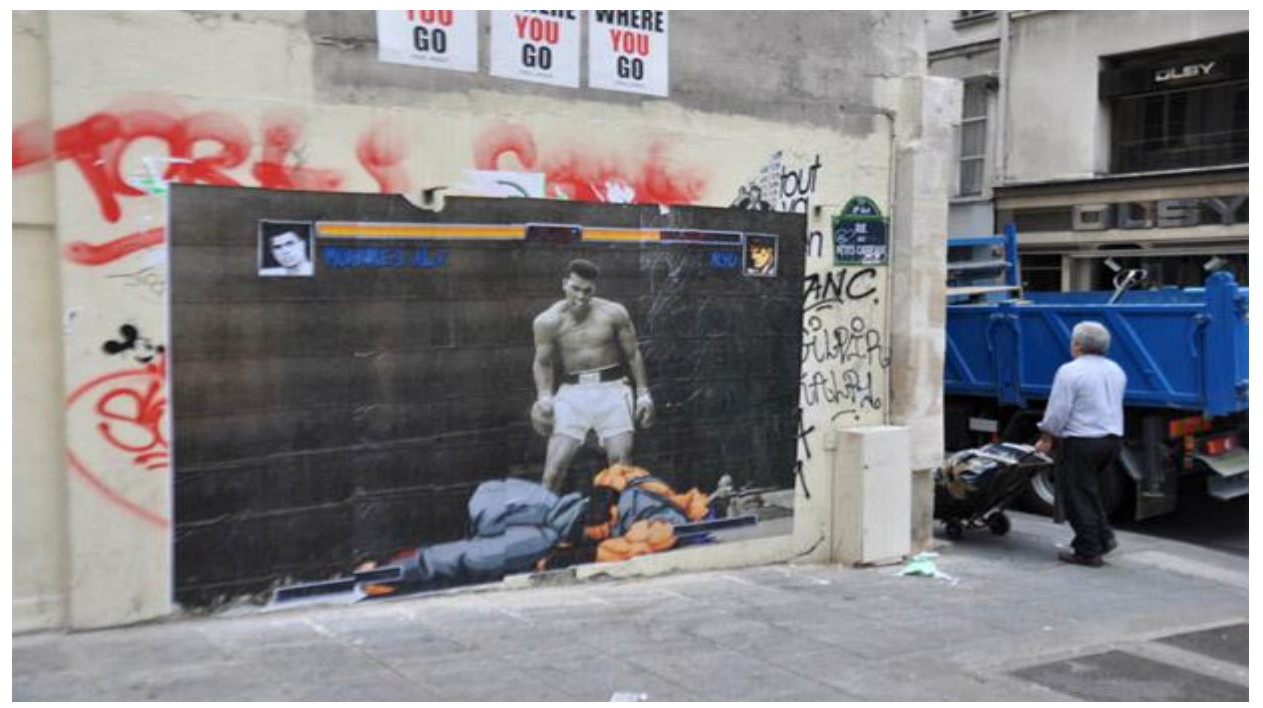

Figura 28 - Muhammad Ali vs. Ryu

Fonte: Kineda. Título do site. Disponível em: 〈http://www.kineda.com/muhammad-ali-vs-ryu/>
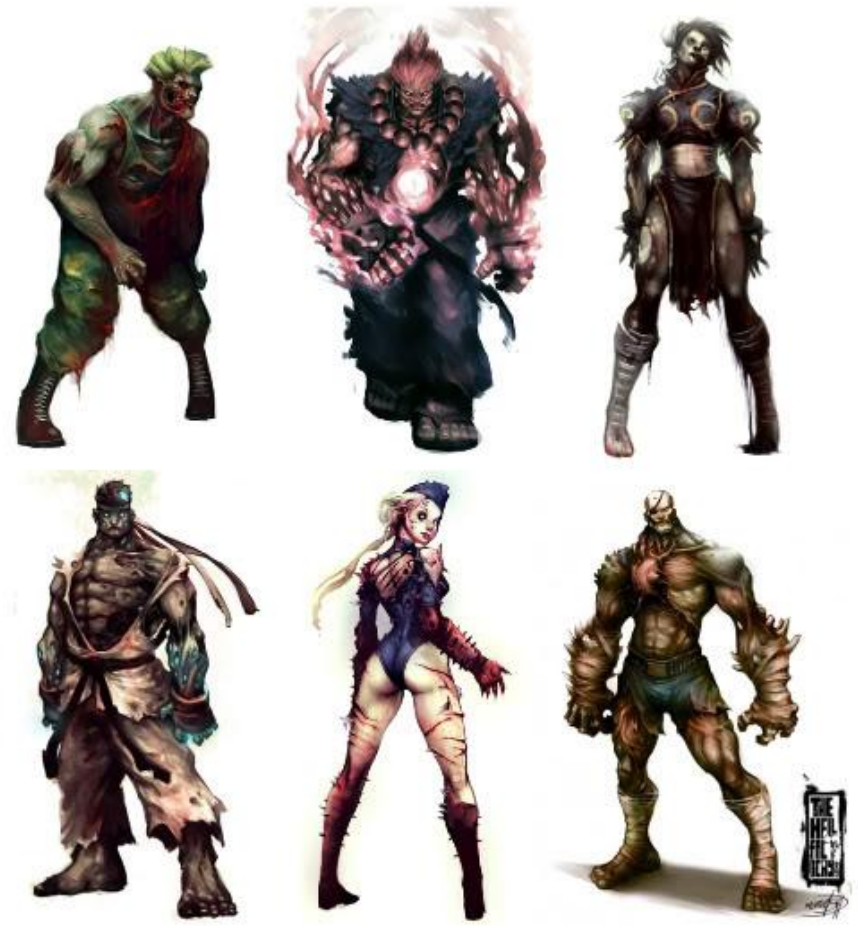

Figura 29 - Street Fighter Zoombie

Fonte: Photo Bucket. Disponível em: <http://i278.photobucket.com/albums/kk93/jabaya/20141_full.jp〉 


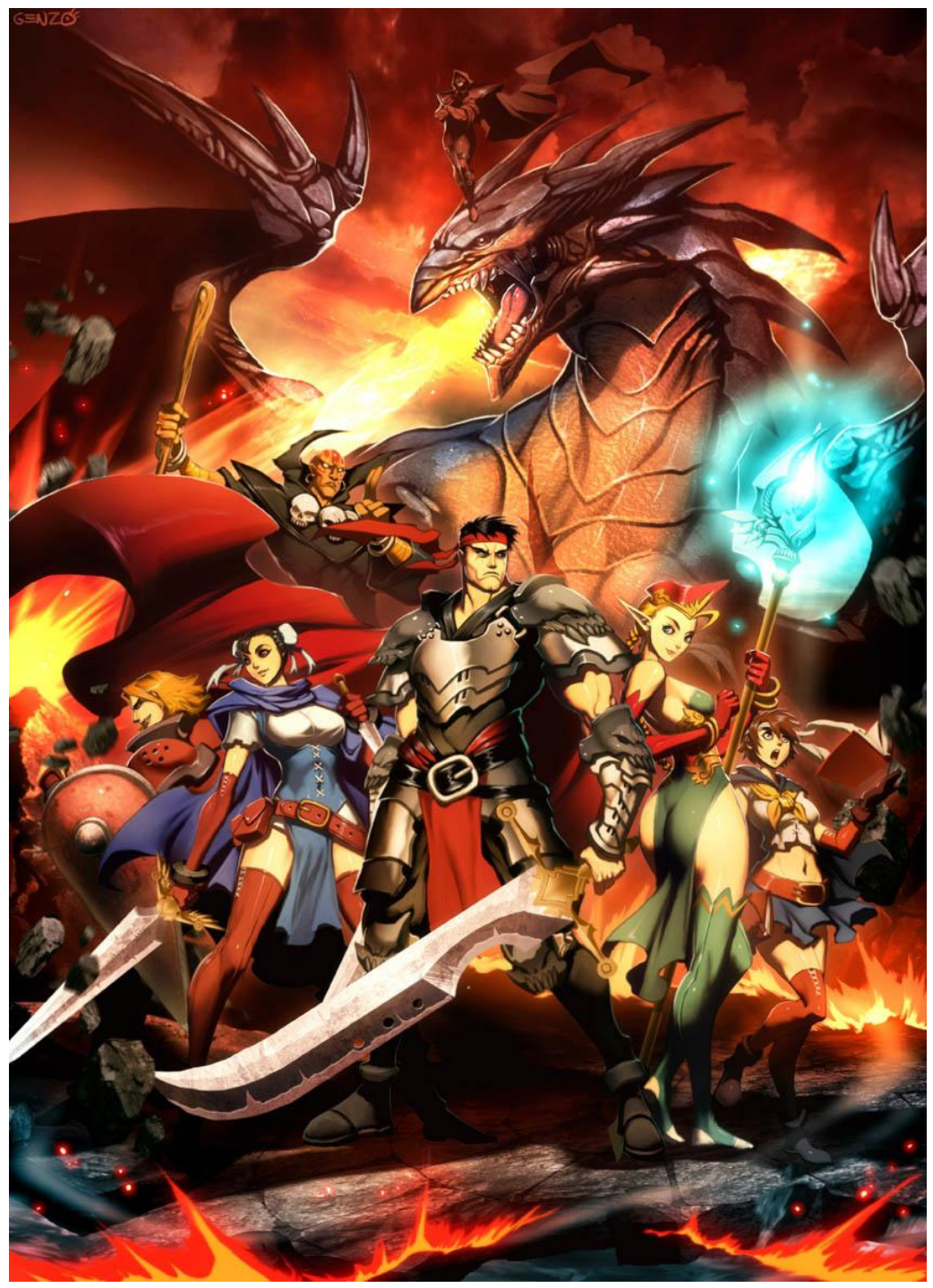

Figura 30 - Street Fighter Medieval

Fonte: Neogamer. Disponível em: <http://neogamerbr.blogspot.com.br/2011/02/gameart-street-fightermedieval.html >

Alguns elementos contidos no jogo Street Fighter extrapolaram o próprio jogo e passaram a ser uma referência icônica, com palavras e gestos de um nicho cultural específico, como as expressões "Hadouken" e "Perfect". A presença desses signos pode ser vista em ironias referenciais de revistas, memes e em outras situações adversas. 


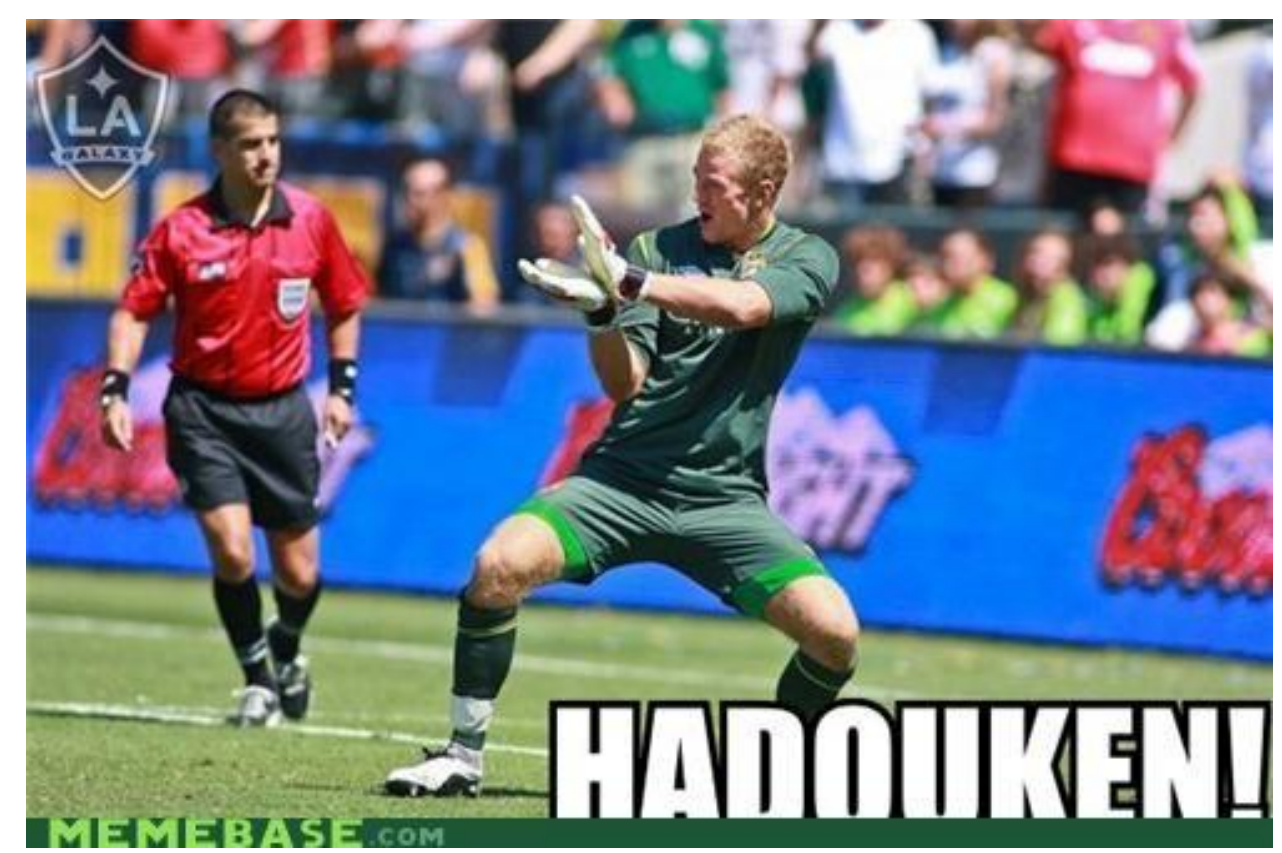

Figura 31 - Memes Joe Hart Hadouken

Fonte: Meme Base. Disponível em: < http://www.sharenator.com/Memebase_78/memes_joe_hart_hadouken212624.html >

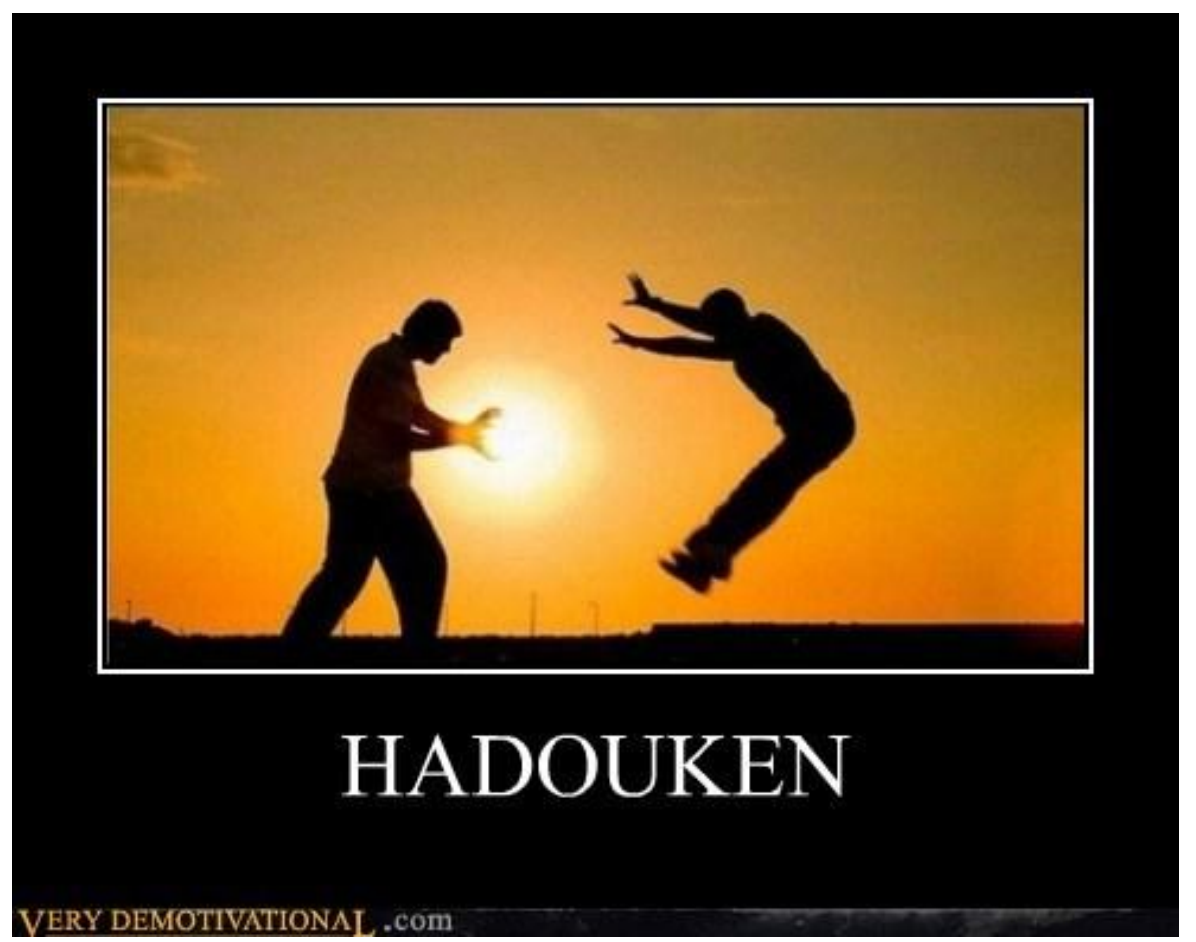

Figura 32 - Hadouken.

Fonte: Meme Base. Disponível em:

<http://memebase.cheezburger.com/verydemotivational/tag/hadouken> 


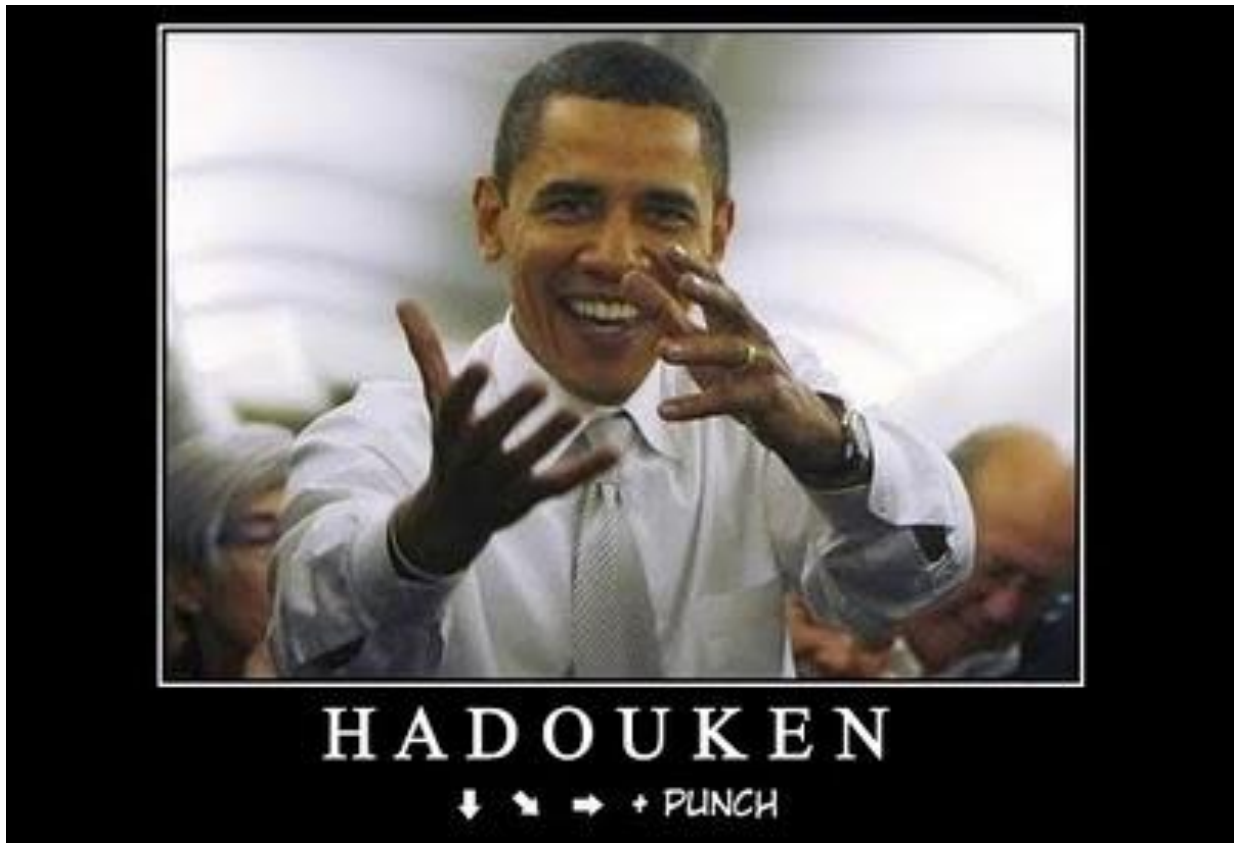

Figura 33 - Obama... Hadouken!!!.

Fonte: AAFFFFF. Disponível em: <http://aafffff.wordpress.com/2009/08/03/obama-hadouken/>

\subsection{Técnica de investigação}

Para a análise de Super Street Fighter IV, valemo-nos da gravação de uma partida do jogo do Ryu, disponibilizada no Youtube.com por Uzumaki ${ }^{9}$ (2012). Trata-se de uma prática cada vez mais comum entre jogadores, uma vez que os jogos vêm com opções para gravação e disponibilização da partida on-line para outros espectadores. É uma nova função que permite jogar e também assistir ao game. Nisso estão contidas estratégias das grandes produtoras que visam combater a pirataria, não permitindo àqueles que não estiverem de acordo com os padrões de mercado mostrar à comunidade de jogadores suas habilidades na rede.

Em seguida, na sequência que mostra como funciona um jogo - muito embora, para uma experiência completa seja necessário, também, jogar-, pudemos observar:

- as imagens que compõem o jogo e como elas criam a narrativa do personagem escolhido;

- os avanços no jogo permitem acompanhar o desenvolvimento da história;

\footnotetext{
${ }^{9}$ Disponível em: <http://www.youtube.com/watch?v=VxDNMXq1Y5I>.
} 
- os elementos de jogabilidade;

- as relação da comunidade com os comentários postados na timeline do vídeo.

Para o estudo do game que é o objeto de estudo, utilizamos os instrumentos de análise:

- o diagrama ludológico proposto por Juul (2003);

- o diagrama de narrativa embutida proposto por Chatman (1978);

- o diagrama de narrativa de emergente proposto por Dubiela e Battaiola (2007).

\subsubsection{Diagrama Ludológico}

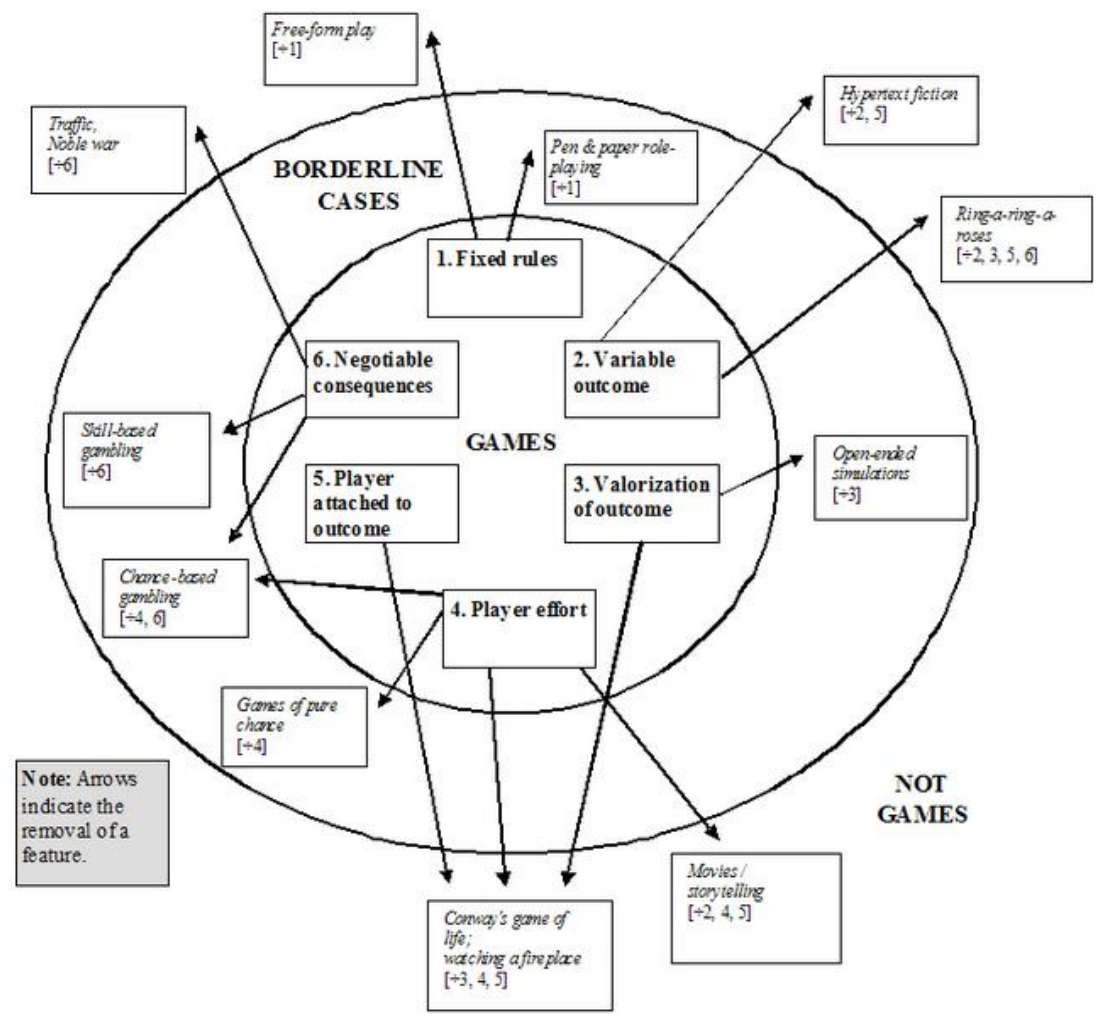

Figura 34 - Game Diagram

Fonte: Juul (2003)

Como tradução livre da citação, temos:

1) Regras;

2) Recompensa;

3) Valor atribuído a resultados possíveis;

4) Esforço do jogador/desafio;

5) Conexão entre o resultado e o jogador;

6) Consequências negociáveis. 


\subsubsection{Diagrama de Narratologia}

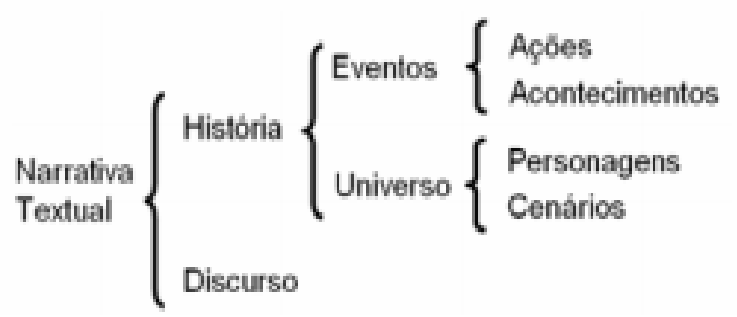

Narrativa emergente

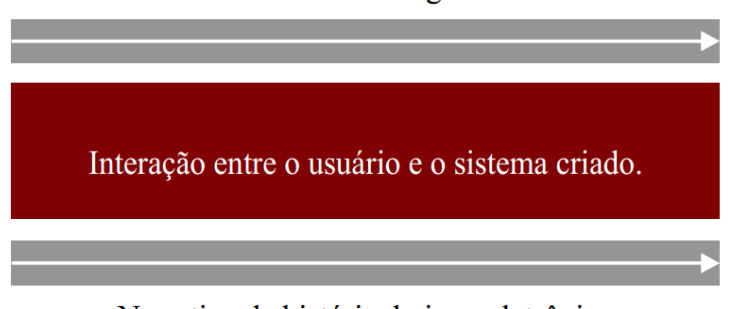

Narrativa da história do jogo eletrônico

Figura 35 - Narrativa Embutida (CHATMAN, 1976) e Emergente (DUBIELA; BATTAIOLA, 2007) Fonte: Organizado pelo autor

O diagrama de Chatman (1978) aplica-se à compreensão da narrativa embutida, construída pelos roteiristas da obra e comum a todos que a acessarem. Tal diagrama baseia-se em compreender em como estruturam os elementos na obra. À medida que são identificados e preenchidos, tem-se uma visão geral de como a textualidade se apresenta. O diagrama de narrativa emergente proposto por Dubiela e Battaiola (2007) deixa claro que existe uma questão temporal envolvida, de ordem progressiva, que à medida que o usuário avança, sua prática de interação com o sistema promove uma maior profundidade de como é vista a narrativa. A narrativa emergente pode ser considerada a associação da narrativa embutida com o ato de jogar.

\subsubsection{Guia de análise fílmica}

A análise fílmica foi embasada nos pressupostos descritos por Vanoye e Goliot-Lété (1994), e consiste em um tratado no qual uma série de aspectos relacionados ao filme foram expostos e sistematizados, direcionando o olhar do pesquisador e orientando seus esforços às atividades de pesquisa e análise. $\mathrm{O}$ aspecto a ser enaltecido para o analista é a postura de pesquisador (que precisa se distanciar do fruidor normal), orientando sua conduta para:

- ser ativa, consciente, racional e estruturada; 
- olhar, ouvir, observar e examinar o filme de uma maneira técnica, procurar indícios;

- submeter o filme às suas hipóteses/conjecturas e aos instrumentos de análises;

- manter processos de distanciamento;

- ver o filme como uma produção intelectual e pertencendo ao campo da reflexão.

Tais técnicas de análise contam com itens diversos, mas nem todos são aplicados aos jogos de videogame. São eles:

1. Numeração do plano - parte contida na relação de início e final de uma tomada, que tem conexão com o plano anterior e plano posterior:

a. duração em segundos

2. Elementos visuais representados

Definição da imagem: cor/preto e branco, "grão" de fotografia, iluminação, composição plástica, etc;

Efeitos;

Combinações estéticas.

3. Escala dos planos, incidência angular, profundidade de câmera, objetiva utilizada.

a. Ângulo de filmagem (tomada frontal e lateral, plongeé/contra-plongeé, etc.)

b. Escala (lugar da câmera em função do objeto filmado), plano geral ou de grande conjunto, plano de conjunto ou meio conjunto, plano médio (homem em pé), plano americano (acima do joelho), plano próximo (cintura, busto), primeiríssimo plano (rosto), plano de detalhe (insert, pormenor).

c. Enquadramento: inclui o lugar da câmera, a objetiva escolhida, o ângulo de tomadas, a organização de tomadas e de espaços e dos objetos filmados no campo.

d. Profundidade no campo: de acordo com a objetiva escolhida, a iluminação, a disposição dos objetos no campo, o lugar da câmera, a parte do campo nítida, visível, será mais ou menos importante.

e.Situação do plano de montagem, no conjunto do filme: Onde? Em que momento? Entre o quê e o quê?

\section{Movimentos}

a. Fixo ou em movimento (câmera fixa/câmera em movimento, travelling, panorâmica, movimento com grua, câmera na mão, objetiva fixa, zoom, movimento ótico, etc.)

5. Encadeamento de sequenciais e passagens de um plano para outro;

a. Perfis sequenciais: 
- número e duração de sequências;

- encadeamento: rápido/lento, corte seco/demarcado, cronologicamente marcado/acronológico, logicamente motivado/não claramente motivado, contínuo/descontínuo;

- ritmo inter e intrarrelacional: rápido/lento, seco/suave, contínuo/descontínuo.

6. Trilha sonora

a. música

b. ambiente

c. personagem

7. Relações entre som e imagem

a. Narrador e instância narradora:

- extradiegético

- à beira da diegese

- ser um personagem.

b. Sub-narrativas do personagem:

- focalização visual;

- focalização auditiva;

c. Ponto de vista e ponto de escuta:

- de onde se vê aquilo que se está vendo?

- quem conta a história? é algo detectável?

- ponto de vista no sentido ideológico, juízos de valores sobre os personagens que o filme expressa ou induz,

- de onde se ouve aquilo que se ouve?

- quem ouve e quem escuta, o personagem e o usuário escutam a mesma coisa?

- distinguir sons objetivos de sons subjetivos;

- destacar convergências entre pontos de escuta e pontos de vista.

\subsection{Coleta}

A fonte principal de coleta de informações foi o vídeo postado no Youtube pelo usuário Sazuke Uzumaki. Perante a linguagem cinematográfica, gravar as telas de jogo recebe 
o jargão do cinema chamado de registro de intervenção in situ, ou seja, algo que serve para divulgar o que ocorre além do lugar que é produzida tal captação.

A seguir, apresentamos a página do canal desse usuário no Youtube:

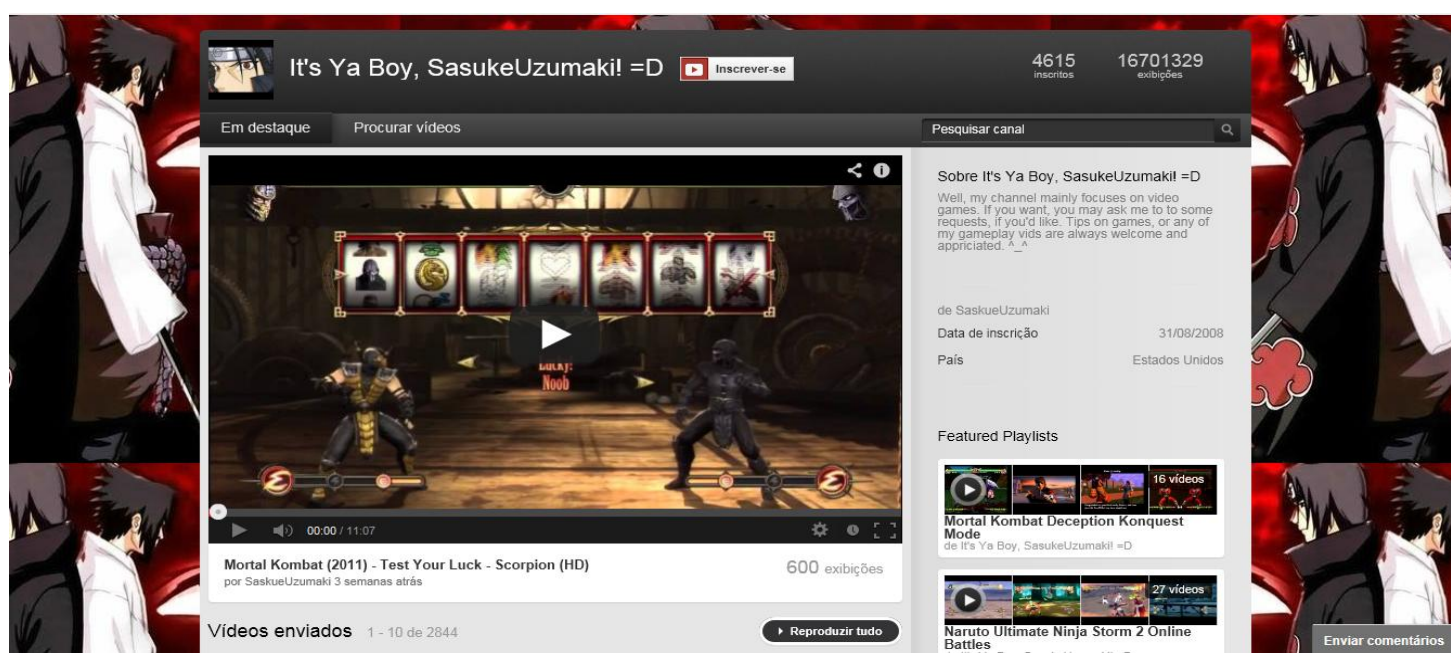

Figura 36 - Perfil do usuário Saskue Uzumaki

Fonte: Youtube. Disponível em: http://www.youtube.com/user/SaskueUzumaki?feature=watch>

Trata-se de um perfil de usuário voltado para gravar partidas de jogos filmadas e disponibilizadas na internet. Foram postados até o momento da criação dessa tabela 2819 vídeos, em um intervalo de tempo que se estende de 30 de janeiro de 2008 a 15 de fevereiro de 2013. Além do Street Fighter 4, vemos uma série de outros jogos, em um total de 115 títulos filmados e alguns vídeos de promoção do canal, uma resenha de jogo, pessoas conversando sobre jogos e até mesmo uma modalidade de curta-metragem chamada Bump Videos, promovida pelo canal de desenhos Adult Swim. Destacam-se os vídeos de M.U.G.E.N., espécie de engine de jogo de luta que, com o código aberto, permite jogar com personagens de diferentes franquias, nas quais o jogador tem a liberdade de configurar uma série de padrões diferente de um jogo tradicional.

Os vídeos sobre jogos dividem-se em dois tipos: 1) walktroughs - um passo a passo do jogo, do começo ao fim e em que se revela o que acontece e a forma de estratégia para enfrentar os adversários; 2) sessões de jogos filmadas, mostrando confrontos on-line e jogadas épicas.

Descrição do perfil feita pelo próprio usuário: 
Sobre It's Ya Boy, SasukeUzumaki! =D

Well, my channel mainly focuses on video games. If you want, you may ask me to to some requests, if you'd like. Tips on games, or any of my gameplay vids are always welcome and appriciated. ^^^

Número de inscritos: 4621

Total de vídeos: 2844

Total de visualizações: 16701239

Data de inscrição: 31/8/2008

País: Estados Unidos

Pela quantidade de gêneros apresentados e pela reincidência de determinados títulos, fica evidente a preferência do jogador pelos jogos de luta, principalmente os ligados ao anime Naruto. Diariamente, uma ou mais postagens são feitas, sendo que já houve épocas com mais de quarenta vídeos colocados no ar. As postagens possuem níveis de audiência que vão de dezenas a milhares.

Consultar vídeos no Youtube permite conhecer e agregar uma série de outras informações e evidências relacionadas ao objeto, pois em torno da tela existem informações como vídeos relacionados e a timeline do vídeo, onde podemos observar o comportamento de outros internautas sobre a temática.

O vídeo analisado é um walktrough do personagem Ryu no jogo Super Street Fighter 4, que demonstra a supremacia técnica do jogador, servindo para conhecer o jogo e para verificar as estratégias empregadas. A atitude de observar o vídeo só é válida porque o título em questão foi jogado pelo pesquisador, consistindo, portanto, em experiência a ser considerada. 
Comentários da pessoa que enviou o vídeo (SaskueUzumaki)

Chris Vergara 1 ano atrás

evil ryu in this one?

Responder : it e

SaskueUzumaki 1 ano atrás

He's only in Arcade Edition.

Responder * ib el em resposta a Chris Vergara

14shadowspade 1 ano atrás

1. 18 whats the difference b/w this and the arcade version?

Responder . il 21 em resposta a SaskueUzumaki

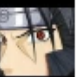

SaskueUzumaki 1 ano atrás

Well, a lot of stuff got patched to make the game more balanced, and the patch included the new 4 characters, Yun, Yang, Oni \& Evil Ryu. There's a 2012 AE patch too.

Responder : it 21 em resposta a 14shadowspade

Todos os comentários (8)

Faça login agora para postar um comentário.

CecilandRosa4ever 1 ano atrás

can $u$ do guile plz and ty :

Responder

Todos os comentários (8)

Faça login agora para postar um comentário.

CecilandRosa4ever 1 ano atrás

can u do guile plz and ty :)

Responder $\cdot$ in

14shadowspade 1 ano atrós

Q. 8 i might check this game out a little more, this could be the game i was looking for

Responder · ib 7) em resposta a SaskueUzumaki (Mostrar o comentário

X1noZhitop 1 ano atrás

epic end

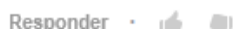

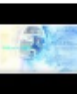

Evyldyn 1 ano atrás

Nice videos Saskue.

Responder

Figura 37 - Timeline de comentários do vídeo utilizado nesta pesquisa

Fonte: Youtube. Disponível em: 〈http://www.youtube.com/watch?v=VxDNMXq1Y5I> 
Constatamos que apenas $1 \%$ dos que viram o vídeo teceu algum comentário. $\mathrm{Na}$ conversa entre os espectadores e o responsável pelo canal foram abordados assuntos sobre personagens especiais, diferença entre as versões e solicitação de um espectador para postagem de um vídeo com outro personagem.

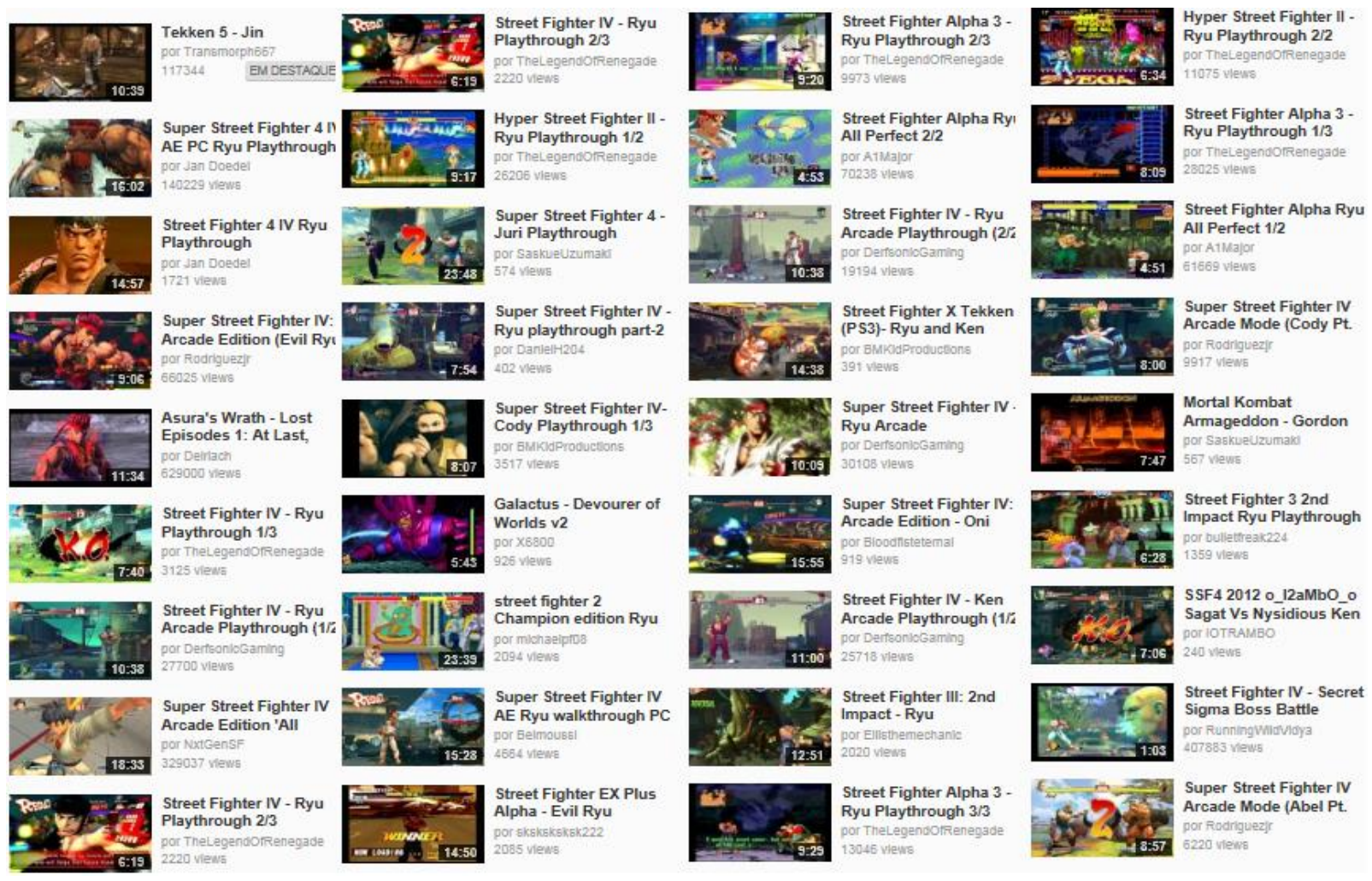

Figura 38 - Mosaico de vídeos postados pelo usuário .

Fonte: Youtube. Disponível em: 〈http://www.youtube.com/user/SaskueUzumaki/videos〉

Além da timeline com o comentário dos que assistiram ao vídeo, outro campo de informação promovido pelo Youtube é o dos vídeos relacionados, uma vez que são propostos ao usuário outros clipes de interesse.

Um dos vídeos que faz referência ao Super Street Fighter é o Sigma Boss Battle, com mais de 400 mil visualizações. Por não se encontrar nada sobre esse personagem, desconfia-se que alguém "hackeou" a estrutura do game e colocou a cabeça do personagem Sagat fora de escala, ampliando-a descomunalmente, promovendo a curiosidade do usuário. Esse vídeo recebeu 1421 likes e 448 unlikes e teve os comentários desabilitados pelo responsável pelo canal. 


\subsection{Processamento e análise de dados}

\subsubsection{Análise Ludológica}

Regras fixas:

O título Super Street Fighter 4 possui regras claras de compreensão e trata-se de um fighting game cujo direcional controla o personagem pela tela e os botões representam golpes como socos e chutes. Combinando as sequências do direcional com golpes, surgem manobras mais complexas que precisam de barras especiais carregadas.

Para jogá-lo não é necessário o domínio de técnicas complexas do game, com vontade de vencer e com golpes básicos encaixados no tempo certo é possível alcançar a vitória. À medida que se avançam as experiências com o game e que aumentam as dificuldades, torna-se necessário desenvolver novas técnicas, melhorando os movimentos especiais que levarão a novas formas de competir e vencer. A condição de vitória é acabar com a barra de energia do oponente.

\section{Recompensas:}

- vencer os dois rounds de cada luta;

- aprimorar na sequência de golpes especiais, observar na tela o resultado, seja hadouken flamejante ou uma sequência de animação especial devido ao supercombo;

- avançar no campeonato chegando ao final e ver a sequência de animação.

Sempre no final de cada round aparece as palavras K.O. (knock out), em que o personagem que acabou com a barra de energia do outro faz um gesto próprio de comemoração. Há também a palavra T.O (time over), que dá a vitória àquele que tiver a barra de vida menos gasta.

Outro exemplo de sucesso é vencer o oponente sem perder nada na barra de energia. Caso isso aconteça após a palavra “K.O.” surge a palavra "PERFECT”. Há outras vantagens trazidas pelo jogo, que extrapolam a mecânica e "gamificam" a estrutura das redes sociais e da própria jogabilidade. Caso o jogador faça uma determinada pontuação, pode ter seu jogo gravado e exposto na rede, sua partida e sua vitória deixam de ser um momento de prazer 
individual e restrito ao seu ambiente, passando a ser pública para a rede estabelecida por jogadores conectados à Internet.

Valor atribuído a resultados possíveis:

Esse jogo possuiu uma variabilidade muito expressiva de combinações de movimentos, em que o usuário interage em oito diferentes direções. Além de todo um desempenho de defesa necessário para se esquivar dos golpes, existem seis opções básicas, compostas por três chutes e três socos, combinações específicas, combos entre outras. Devido à velocidade do jogo já consideradas em algumas versões por estarem acima dos reflexos humanos, as ações devidamente encadeadas podem acontecer muito rapidamente, atingindo a média de movimento em algumas ações entre 0 a 1 segundo. Com o desenrolar do jogo, novas configurações de movimentação por parte dos lutadores vão sendo desenvolvidas, assim como a necessidade constante de criar estratégias diferentes. Semelhante ao xadrez pela extensa possibilidade de jogadas, mas com tempos diferentes, a capacidade de analisar, agir e criar ciladas ocorre de forma quase que instantânea e a relação de tempo pode ser crucial. Como o catálogo de golpes é variado para uma mesma situação, existem diversas posturas a serem adotadas, umas conservadoras e de resultados mais previsíveis e outras mais agressivas visando romper a estratégia do oponente, quebrando sua zona de conforto e gerando brechas para fazer as devidas sequências de ataque e defesa. Obviamente que, quanto maior a exposição, maior a chance de contra-ataques.

\section{Esforço do jogador/desafio:}

Nesse caso, o esforço do jogador é diretamente relacionado ao resultado. Esta configuração de ações possíveis faz com que seja impossível realizar duas partidas de uma mesma maneira. O grau de variabilidade é grande; a imprevisibilidade, a negociação entre risco e sucesso presente, o aprimoramento e a sorte são situações que possibilitam um jogo com infinitas possibilidades. Vencer uma vez uma partida não significa vencê-la novamente, pois para isso, é preciso exercitar-se constantemente. 
Conexão entre o resultado e o jogador:

Todos aqueles que se dedicam a finalizar o arco de lutas proposta pelo Story Mode vibram no final. Alegria ou frustração são sentimentos iguais aos vivenciados quando dois jogadores se enfrentam. A necessidade de superar o desafio, a sensação da derrota e a vontade de tentar novamente até conseguir vencer é uma condição que exige muita concentração e técnica do jogador. Os resultados desses esforços podem ser vistos nos desgastes dos controles dos fliperamas após algum tempo de uso. Outro exemplo está associado diretamente às várias opções de botões existentes. Na primeira versão existiam apenas dois com variações entre fraco, médio e forte que se dava pelo nível da pressão no botão acionado e um mecanismo hidráulico condicionava a intensidade do aperto ao resultado em tela. Porém, tal estrutura não suportou ao ímpeto de esforços que eram aplicados.

\section{Consequências negociáveis:}

O jogo analisado, via de regra, fica restrito à virtualidade da tela, mas algumas condições específicas podem trazer consequências para a vida real. Da lista de itens que o jogo influi na realidade, listamos: os atletas de e-sport, colecionismo de "memorabilia"; spinofs (filmes, animações), etc.

O foco que gostaríamos de salientar está diretamente relacionado com a questão de poder promover ao usuário o gosto por uma cultura que está presente na cadeia simbólica dos jogos (no caso a influência da prática das artes marciais, o aprofundamento na cultura oriental e como este título pode ser utilizado em função das necessidades pedagógicas específicas de cada educador e contexto escolar).

Ressaltamos ainda que o Super Street Fighter 4 como um instrumento de análise midiática pode permitir o desenvolvimento de novas relações com a cultura audiovisual, baseando-se em questões de protagonismo e empoderamento, uma vez que a manipulação do conteúdo pode aproximar-se de outras linguagens audiovisuais e até mesmo servir de base para exercícios de game design (análise, criação, escrita criativa, programação, etc.). 


\subsubsection{Análise Narratológica}

\subsubsection{Narrativa Embutida}

\section{1) Discurso}

O discurso é uma opção que a história escolhe para ser descrita e onde mediante os recursos estéticos e técnicos, encaminha-se o seu desenrolar.

Por se tratar de uma maneira complexa de discurso, sua explicação não pode ser dada através das linhas formais, uma vez que envolve toda uma questão de narrativa e interatividade associadas a questões diversas como escolha de personagem e estratégia a ser empregada para fechar o ciclo proposto.

Um tipo de melhor compreensão para o discurso neste contexto é observá-lo perante o aspecto do hipertexto, uma vez que existe uma série de linguagens específicas e uma vasta possibilidade combinatória. $\mathrm{O}$ desencadeamento dos fatos tem por embasamento a própria perícia do jogador, associando-se a isto imagens sequenciais que em determinados momentos variam de acordo com a ação do usuário. Desta forma, criam-se possibilidades que só podem ser compreendidas e analisadas perante uma abordagem ampla e geral.

No jogo em questão vemos o discurso aparecendo em função de telas diferentes e de maneira alternada, com a seguinte ordem (Figura 39):

1. Seleção de personagem

2. Animação inicial

3. Luta contra um adversário

3.1 Sequência inicial de apresentação na arena e diálogo inicial

3.2 Jogo

3.3 Tela final com uma mensagem de vitória/derrota

4. Surgimento do rival

4.1 Sequência inicial de apresentação na arena e diálogo inicial

4.2 Jogo

4.3 Tela final com uma mensagem de vitória/derrota

5. Luta final

5.1 Sequência inicial de apresentação na arena e diálogo inicial 


\subsection{Jogo}

5.3 Tela final com uma mensagem de vitória/derrota

6. Sequência de telas

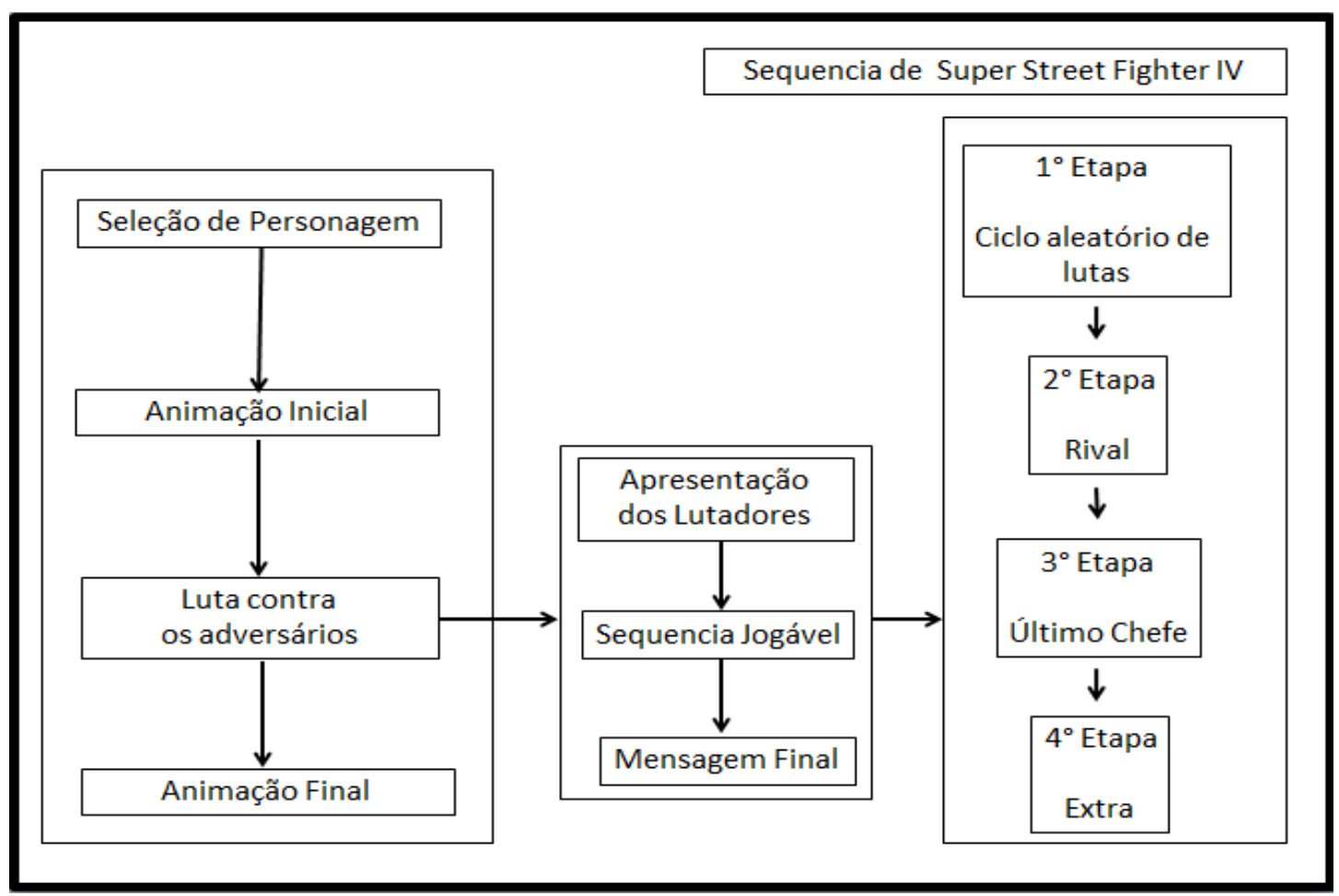

Figura 39 - Sequência de Super Street Fighter IV

Fonte: Organizado pelo autor

\section{2) História}

A história do Super Street Fighter 4 é uma continuação da primeira versão lançada há 25 anos. Com o passar do tempo, houve a necessidade de justificar a existência dos personagens e qual a razão de eles terem entrado para aquele torneio. $\mathrm{O}$ avanço da tecnologia, a qualidade gráfica de animações e até mesmo a expansão do mercado de entretenimento possibilitaram diversas formas para se aprofundar na vida dos personagens, criando um vínculo de gosto e de afetividade com tudo que é representando pelas características que os compõem. O conteúdo na tela representa o lutador em uma arena, onde cada qual com sua perícia e motivação, está no torneio para buscar o seu melhor e se sagrar vencedor. Tais objetivos condutores são clichês das narrativas de artes marciais, nas quais está implícito 
provar que é o melhor, o guerreiro abnegado, o vilão que quer dominar o mundo, vingança pela morte de um parente, fama, dinheiro, entre outros.

Ressaltamos o fato que Ryu, ao finalizar o jogo, deixa sua mensagem em forma de reflexão, questionando-se sobre o quanto realmente evoluiu e o quanto suas técnicas são superiores em relação aos outros lutadores. Encerra o episódio e sua fala com uma frase remetendo a próximos encontros. Nesse momento, seu poder principal - a esfera de energia corta a cachoeira ao meio. Vale ressaltar que em um dos vídeos introdutórios, Gouken, seu mestre, com um tapa abala a água da cachoeira ${ }^{10}$. Além do elo entre vídeos de trailer e final da aventura temos uma relação de quanto o arco narrativo pode ser desenvolvido, a relação do mestre e do discípulo, a vontade de lutar e comprovar o pode novamente, o simbolismo da água da cachoeira e a relação de quanto um poder necessita para alcançar o outro. Com isso, a afetividade e identidade em relação aos personagens são aprofundadas, inclusive, permitindo novas continuações perante os propósitos de vida dos lutadores.

\section{3) Eventos}

O evento do jogo é o campeonato de artes marciais, que promove o encontro e o enfrentamento entre os personagens. Existe um ciclo inicial de seis lutas, nas quais pode aparecer qualquer um dos personagens, com exceção do rival e daqueles que possuem a fase extra, fazendo com que se torne difícil uma previsão do padrão do jogo. Todo o lutador tem o seu rival e, no caso de Ryu, é o lutador tailandês Sagat. Após enfrentar o último chefe, a luta extra é contra o personagem Akuma. São poucos personagens nesta fase e o jogador ao se deparar com ela, tem a sensação de que algo diferente foi deixado para o final.

\section{4) Ações}

É o modo como esses personagens interagem usando suas habilidades e técnicas para derrotar o oponente e manter-se na competição. Existem as Fases Bônus. Na versão 3, existia a escolha de rounds e dos adversários, porém, na atual, voltou-se ao modelo padrão.

\footnotetext{
${ }^{10}$ Disponível em: 〈http://www.youtube.com/watch?v=VyhNxbapFEc >
} 


\section{5) Acontecimentos}

São os fatos que ocorrem e justificam as ações. No primeiro ciclo, aparece uma ordem aleatória de personagens como se fosse uma chave sorteada com grande quantidade de variações, proporcionando a condição do inesperado e do ineditismo. Assim, a cada partida, há uma configuração combinatória diferente.

\section{6) Universo}

O Universo do jogo é parecido com o mundo no qual vivemos, porém, apresenta uma particularidade própria como, por exemplo, a condição fisiológica que permite um alto grau de escoriações e com gravidades bem distantes da nossa realidade. Somam-se a isso questões ficcionais, sejam místicas, sejam tecnológicas, que fazem parte dos personagens, dando a eles energias sobrenaturais exteriorizadas através de poderosos golpes baseados na mitologia oriental, com sequências que ignoram a gravidade - lembrando os filmes onde lutadores voam de um lado para outro, denominados wu-xia, wire-fu, realizados pela produtora de Hong Kong Shaw's Brothers.

\section{7) Personagens}

Os personagens são baseados em arquétipos associados às suas respectivas nacionalidades, marcados pela constituição física e principalmente pelas roupas usadas. Muitas vezes, a representação estereotípica das identidades faz-se de modo tão presente e às vezes tão caricatural que existem estudos sobre esta faceta do jogo, conforme podemos ver na Figura 40, a seguir: 


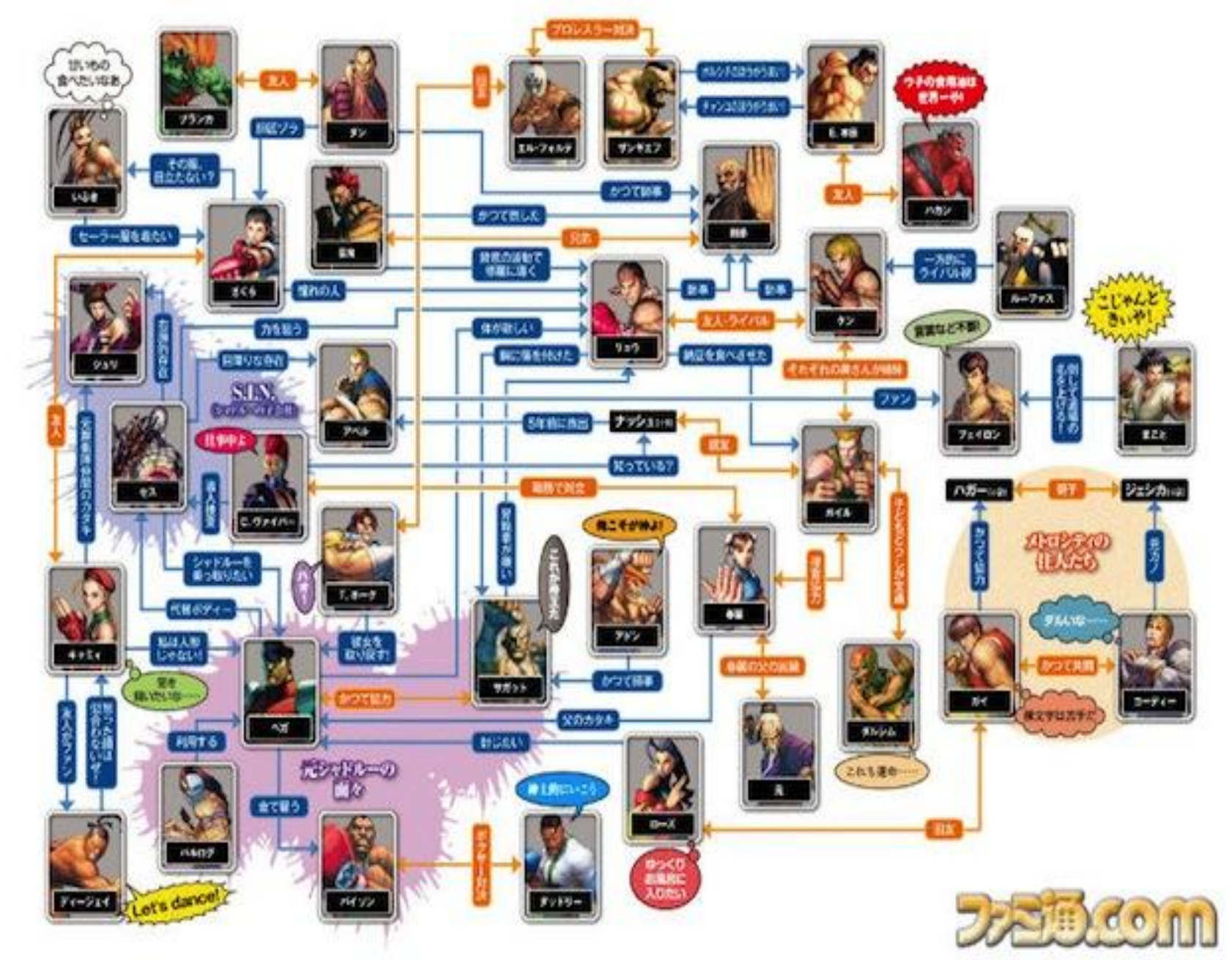

Figura 40 - Super Street Fighter IV - Relationship Chart

Fonte: Destructoid. Disponível em: <http://bulk2.destructoid.com/ul/178485-2132419301_view.jpg>

Na Figura 40, um gráfico de relacionamentos feito por um fã, mostra os personagens do Super Street Fighter 4 e o nível de relacionamento entre eles, tais como aliado, mestre/ discípulo e rival. Nesta versão do jogo o rival tem um papel importante, pois antes do último chefe, o rival do personagem que se está jogando aparecerá para confrontá-lo, com isso haverá um texto específico para cada um dos lutadores, além de mensagens de vitória e derrota.

Tais laços implicam em questões de relacionamento desenvolvido pelos personagens levando em consideração o que ocorreu nos últimos 25 anos da série, como a rivalidade entre Ryu e Sagat, chefe final do primeiro jogo que, ao ser derrotado pelo herói adquire a cicatriz 
em seu peito. Em sua luta existe um diálogo específico exaltando essa situação advinda de fatos pretéritos. Em contrapartida, novos lutadores surgiram, iniciando-se novas tramas, como, por exemplo, o chefão Seth e o Gouken.

Diferentemente dos jogos nos quais são nítidas as transformações do personagem através de diferentes equipamentos, poderes, painéis de evolução ligados, entre outras possibilidades que se refletem na morfologia fenotípica, o Street Fighter não possui esse caráter. Embora haja uma transformação, esta advém do próprio jogador promovendo resultados como vitórias, perfects, combos e especiais.

\section{8) Cenários}

Os cenários repetem a estrutura proposta pelos personagens, nos quais eles são representações estereotípicas e caricaturais dos países representados, mostrando uma afinidade de cores, animações e detalhes nos gráficos. Essa riqueza de elementos muitas vezes passa despercebida pelo jogador, que foca a atenção em seu personagem e no do adversário.

Outro fator de diferença em relação ao Street Fighter 4 é que desta vez os personagens controlados pelo computador não ficam fixos aos seus espaços autóctones. Em outras versões, o jogador avançava pelo mundo, visitando cada um dos personagens em seu cenário, mas, nesta versão, os encontros são aleatórios e os personagens enfrentados estão em lugares diferentes de sua nacionalidade. Isto confere ao jogo um maior grau de casualidade, em que as brigas de rua acontecem para todos, diferente de outras versões nas quais mostrava que só o jogador estava viajando para enfrentar seus oponentes.

\subsubsection{Narrativa Emergente}

Segundo Dubiela e Battaiola (2007), a narrativa emergente se estabelece da relação entre jogador e o sistema em uma seta de tempo que segue em sentido ao infinito. Quanto mais o usuário passar o seu tempo conectado ao jogo (jogando ou se relacionando com os ícones), maior será o sentido emergente que ele desenvolverá.

Outro aspecto que deve ser ressaltado é o tempo de duração de um jogo, uma vez que uma partida de dois ou três rounds dura aproximadamente de dois a três minutos e uma sessão tem tempo mínimo de aproximadamente quinze minutos e um máximo indeterminado. $\mathrm{O}$ tempo de jogo está diretamente relacionado à necessidade de o jogador continuar se 
aprimorando. Diferente de um jogo de RPG, no qual o personagem pode mudar, comprar equipamentos e evoluir suas habilidades, neste jogo o personagem permanece o mesmo do começo ao fim. Outro aspecto importante é que nessas duas décadas, o jogo ganhou novos incrementos, novas sequências de animação e novos golpes, porém, manteve inalterada a sua essência. Um indivíduo que jogou a versão II não terá que aprender tudo de novo. Um tempo de adaptação será suficiente para que ele se atualize.

Complementando o que Dubiela e Battaiola (2007) afirmam dentro do eixo de tempo, vemos a relação de temporalidade, assim como Gould (1991) que propõe: o tempo em seta e o tempo em ciclo, ou seja, uma cadência do zero ao infinito como, por exemplo, a idade dos seres vivos. Há ciclos com horas, semanas e anos, uma unidade escalar finita para encaixar-se em uma linha infinita, portanto, dentro de uma linha na qual se insere a vida estão as partidas e as seções onde sempre que uma acaba outra se inicia. Considerando que o jogo é uma trajetória sucessiva de escolhas, temos uma narrativa de tentativas e erros buscando a melhor estratégia, uma das formas emergentes é a busca pela vitória mediante a estruturação tática que varia a cada momento, seja pela vasta quantidade de golpes por segundo que o jogador tem a opção de escolher e aprimorar, seja pela inteligência artificial que sugere se adaptar aos padrões do jogador e buscar maneiras de dificultar o avanço dele, exigindo que este se a aprimore e evolua.

\subsubsection{Análise Fílmica}

Para a análise fílmica, optou-se por utilizar os campos descritos pela metodologia apresentada, porém de uma forma livre, não necessariamente interativa, mas sim aberta, após uma série de vezes que o video foi assistido (com o som, sem o som, de olhos vendados para aguçar a audição) concomitantemente com diversas sessões de jogabilidade. Baseamo-nos na temporalidade Metapórica (MARCONDES, 2010), na qual existe o pico de êxtase e posteriormente uma pregnância latente do efeito da obra na "razão durante" de contato com o fruído. Foram mantidos os tópicos originais da proposta de análise fílmica que preenchidos em função da experiência prévia com a obra, de modo que houvesse um preenchimento que, embora sistêmico, tivesse um caráter menos cartesiano. 


\section{1) Numeração do plano, duração em segundos ou número de fotogramas:}

Os planos podem ser descritos como o intervalo temporal de uma passagem para outra, porém, ao fazer a sua contagem e a tomada de tempo de cada um, caracterizou-se uma diferença entre o cinema e o videogame, pois, muitas vezes mesmo o plano se mantendo, existe uma diferença no que é transmitido, criando um impacto na postura do jogador frente sua interatividade. Os planos para a pesquisa respeitaram a seguinte caracterização:

- Anúncio: telas que antecedem a luta, mostrando quem será o adversário e o cenário, apresentando imagens paradas.

- Animação de jogo: no início das lutas, existe uma sequência de animação do personagem que, de alguma maneira, profere frases de desafio e coloca situação de combate. A transição dessas imagens e a luta acontecem de maneira fluida, traçando uma continuidade entre os dois tipos de planos;

- Animação narrativa: trata-se da sequência que existe no começo e no fim do jogo, expondo o personagem no momento pré-combate. Esta sequência tem um traço mais rebuscado que a animação de jogo, devido ao caráter de importância que o jogador atribui, principalmente à animação final, terminar o jogo em seu modo de história (story mode) é considerado uma das recompensas. Além disso, tais trechos podem revelar detalhes sobre a história do jogo ou do personagem.

- Inicialização e finalização do round: neste caso temos uma divergência entre as questões fílmica e o videogame, pois embora no contexto da jogabilidade, estes anúncios têm um sentido e uma dinâmica completamente diferentes;

- Jogabilidade: trata-se do jogo em si, onde efetivamente ocorre a ação, a partida;

- Info: ao derrotar o opoente aparece uma tabela atribuindo uma nota e índices de ataque, defesa e técnica.

Com isto, temos as seguintes unidades: Animação Inicial; Tela preta "loading"; Tela de anuncio de estágio; Tela de anúncio de Personagens; Tela de Jogo; Tela de Performance e Animação Final. 


\section{Distribuição de tempo total dos Planos do Jogo}

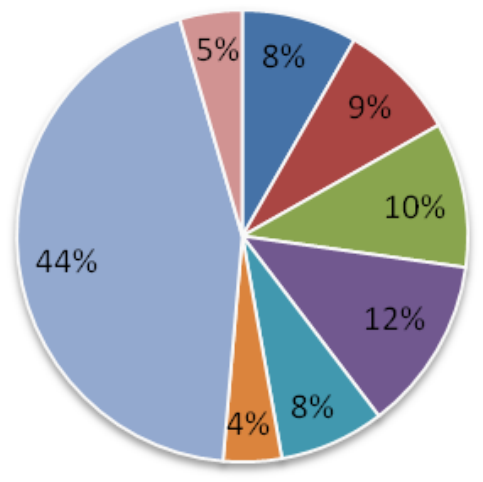

- Animação de Jogo

- Animação Narrativa

Anuncio

- Finalização Round

घ Info

- Inicialização Round

- Jogabilidade

- Info

Figura 41 - Distribuição de tempo total dos Planos do Jogo Fonte: Organizado pelo autor

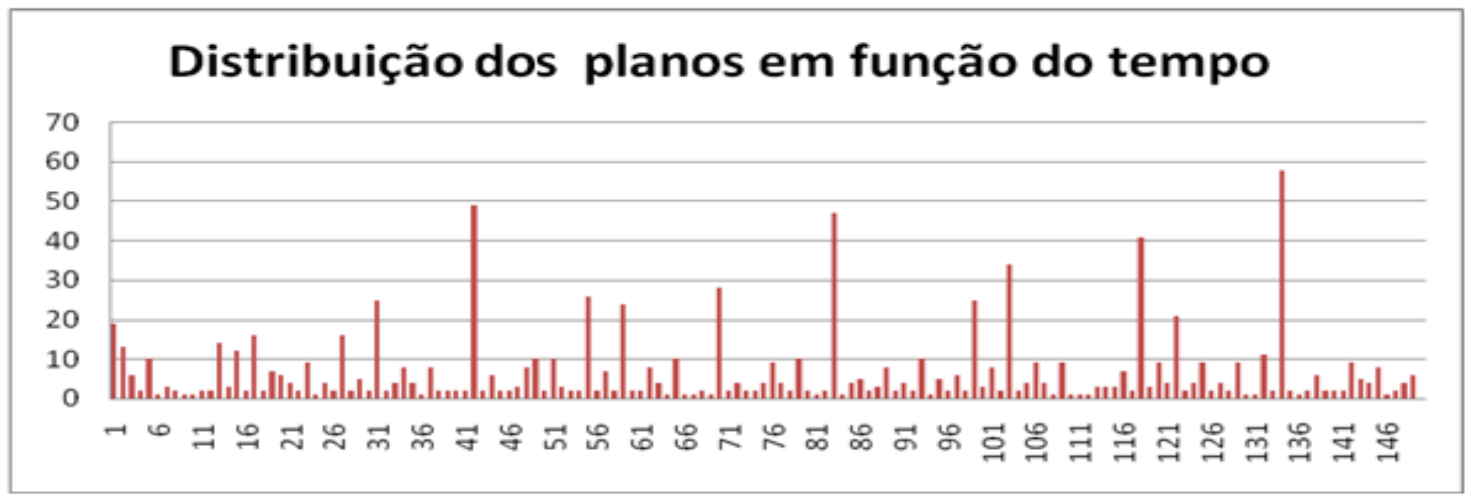

Figura 42 - Distribuição dos planos em função do tempo

Fonte: Organizado pelo autor 
Guia de Referência de identificação de cada plano:

Tabela 5 - Identificação dos Planos

\begin{tabular}{|c|c|c|c|}
\hline & Tipo de Plano & Ocorrência & $\begin{array}{c}\text { Intervalo de } \\
\text { Tempo }\end{array}$ \\
\hline 1 & Animação Narrativa & Animação inicial, parte 1 & $22 "$ \\
\hline 2 & Animação Narrativa & Animação inicial, parte & $19 "$ \\
\hline 3 & Animação Narrativa & Animação inicial, parte 3 & $13 "$ \\
\hline 4 & Loading & Tela preta "Loading" & $6 "$ \\
\hline 5 & Anuncio & Tela de anuncio de estágio & $2 "$ \\
\hline 6 & Anuncio & Tela de anuncio dos lutadores & $10 "$ \\
\hline 7 & Animação de Jogo & Animação pré-luta Ryu, parte 1 & $1 "$ \\
\hline 8 & Animação de Jogo & Animação pré-luta Ryu:, parte 2 & 3" \\
\hline 9 & Animação de Jogo & Animação pré-luta Ryu, parte 3 & $2 "$ \\
\hline 10 & Animação de Jogo & Animação pré-luta Dalshin, parte 1 & $1 "$ \\
\hline 11 & Animação de Jogo & Animação pré-luta Dalshin, parte 2 & $1 "$ \\
\hline 12 & Animação de Jogo & Animação pré-luta Dalshin, parte3 & $2 "$ \\
\hline 13 & Inicialização do Round & Tela de jogo, preparação para combate & $2 "$ \\
\hline 14 & Jogabilidade & Tela de jogo, desenvolvimento da partida, Round 1 & $14 "$ \\
\hline 15 & Finalização do Round & Tela de jogo, anuncio de Nocaute & $3 "$ \\
\hline 16 & Finalização do Round & Tela de jogo, finalização dos movimentos & $12 "$ \\
\hline 17 & Inicialização do Round & Tela de jogo, preparação para combate & $2 "$ \\
\hline 18 & Jogabilidade & Tela de jogo, desenvolvimento da partida, Round 2 & $16 "$ \\
\hline 19 & Finalização do Round & Tela de jogo, anuncio de Nocaute & $2 "$ \\
\hline 20 & Finalização do Round & Tela de jogo, finalização dos movimentos & $7 "$ \\
\hline 21 & Info & Tela de Performance & 6" \\
\hline 22 & Loading & Tela preta "loading" & $4 "$ \\
\hline 23 & Anuncio & Tela de anuncio de estágio & $2 "$ \\
\hline 24 & Anuncio & Tela de anuncio dos lutadores & 9" \\
\hline 25 & Animação de Jogo & Animação pré-luta Abel, parte1 & $1 "$ \\
\hline 26 & Animação de Jogo & Animação pré-luta Abel, parte2 & $4 "$ \\
\hline 27 & Inicialização do Round & Tela de jogo, preparação para combate & $2 "$ \\
\hline 28 & Jogabilidade & Tela de jogo, desenvolvimento da partida, Round 1 & $16 "$ \\
\hline 29 & Finalização do Round & Tela de jogo, anuncio de Nocaute & $2 "$ \\
\hline 30 & Finalização do Round & Tela de jogo, finalização dos movimentos & $5 "$ \\
\hline 31 & Inicialização do Round & Tela de jogo, preparação para combate & $2 "$ \\
\hline 32 & Jogabilidade & Tela de jogo, desenvolvimento da partida, Round 2 & $25 "$ \\
\hline 33 & Finalização do Round & Tela de Jogo, anuncio de nocaute & $2 "$ \\
\hline 34 & Finalização do Round & Tela de jogo, finalização dos movimentos: & $4 "$ \\
\hline 35 & Info & Tela de jogo, performance da luta & $8 "$ \\
\hline 36 & Loading & Tela Preta "Loading" & $4 "$ \\
\hline 37 & Anuncio & Tela de anuncio de estágio & $1 "$ \\
\hline 38 & Anuncio & Tela de anuncio dos lutadores & $8 "$ \\
\hline
\end{tabular}




\begin{tabular}{|c|c|c|c|}
\hline & Tipo de Plano & Ocorrência & $\begin{array}{c}\text { Intervalo de } \\
\text { Tempo }\end{array}$ \\
\hline 39 & Animação de Jogo & Animação pré-luta Blanka, parte 1 & $2 "$ \\
\hline 40 & Animação de Jogo & Animação pré-luta Blanka, parte 2 & $2 "$ \\
\hline 41 & Animação de Jogo & Animação pré-luta Blanka, parte 3 & $2 "$ \\
\hline 42 & Inicialização do Round & Tela de jogo, preparação para combate & $2 "$ \\
\hline 43 & Jogabilidade & Tela de jogo, desenvolvimento da partida, Round 1 & $49^{\prime \prime}$ \\
\hline 44 & Finalização do Round & Tela de jogo, anuncio de nocaute & $2 "$ \\
\hline 45 & Finalização do Round & Tela de jogo, finalização dos movimentos & $6 "$ \\
\hline 46 & Inicialização do Round & Tela de jogo, preparação para combate & $2 "$ \\
\hline 47 & Jogabilidade & Tela de jogo, desenvolvimento da partida, Round 2 & $2 "$ \\
\hline 48 & Finalização do Round & Tela de jogo, finalização dos movimentos & 3" \\
\hline 49 & Info & Tela de Performance & $8 "$ \\
\hline 50 & Loading & Tela Preta "Loading" & $10 "$ \\
\hline 51 & Anuncio & Tela de anuncio de estágio & $2 "$ \\
\hline 52 & Anuncio & Tela de anuncio dos lutadores & $10 "$ \\
\hline 53 & Animação de Jogo & Animação pré-luta Cody, parte 1 & 3" \\
\hline 54 & Animação de Jogo & Animação pré-luta Cody, parte2 & $2 "$ \\
\hline 55 & Inicialização do Round & Tela de jogo, preparação para combate & $2 "$ \\
\hline 56 & Jogabilidade & Tela de jogo, desenvolvimento da partida, Round 1 & $26 "$ \\
\hline 57 & Finalização do Round & Tela de jogo, anuncio de nocaute & $2 "$ \\
\hline 58 & Finalização do Round & Tela de jogo, finalização dos movimentos: & 7" \\
\hline 59 & Inicialização do Round & Tela de jogo, preparação para combate: & $2 "$ \\
\hline 60 & Jogabilidade & Tela de jogo, desenvolvimento da partida, Round 2 & $24 "$ \\
\hline 61 & Finalização do Round & Tela de jogo, anuncio de nocaute & $2 "$ \\
\hline 62 & Finalização do Round & Tela de jogo, finalização dos movimentos & $2 "$ \\
\hline 63 & Info & Tela de Performance & $8 "$ \\
\hline 64 & Loading & Tela Preta "Loading" & $4 "$ \\
\hline 65 & Anuncio & Tela de anuncio de estágio & $1 "$ \\
\hline 66 & Anuncio & Tela de anuncio dos lutadores: & $10 "$ \\
\hline 67 & Animação do Jogo & Animação pré-luta Guile, parte 1 & $1 "$ \\
\hline 68 & Animação do Jogo & Animação pré-luta Guile, parte 2 & $1 "$ \\
\hline 69 & Animação do Jogo & Animação pré-luta Guile, parte 3 & $2 "$ \\
\hline 70 & Inicialização do Round & Tela de jogo, preparação para combate & $1 "$ \\
\hline 71 & Jogabilidade & Tela de jogo, desenvolvimento da partida, Round 1 & $28 "$ \\
\hline 72 & Finalização do Round & Tela de jogo, anuncio de nocaute & $2 "$ \\
\hline 73 & Inicialização do Round & Tela de jogo, finalização dos movimentos & $4 "$ \\
\hline 74 & Jogabilidade & Tela de jogo, preparação para combate & $2 "$ \\
\hline 75 & Finalização do Round & Tela de jogo, desenvolvimento da partida, Round 2 & $2 "$ \\
\hline 76 & Finalização do Round & Tela de jogo, finalização dos movimentos & $4 "$ \\
\hline 77 & Info & Tela de jogo, performance & $9 "$ \\
\hline 78 & Loading & Tela Preta "Loading" & $4 "$ \\
\hline
\end{tabular}




\begin{tabular}{|c|c|c|c|}
\hline & Tipo de Plano & Ocorrência & $\begin{array}{c}\text { Intervalo de } \\
\text { Tempo }\end{array}$ \\
\hline 79 & Anuncio & Tela de anuncio de estágio & $2 "$ \\
\hline 80 & Anuncio & Tela de anuncio dos lutadores & $10^{\prime \prime}$ \\
\hline 82 & Animação do Jogo & Animação pré-luta C.Viper, , parte 2 & $1 "$ \\
\hline 83 & Inicialização do Round & Tela de jogo, preparação para combate & $2 "$ \\
\hline 84 & Jogabilidade & Tela de jogo, desenvolvimento da partida, Round1 & $47^{\prime \prime}$ \\
\hline 85 & Finalização do Round & Tela de jogo, anuncio de nocaute & $1 "$ \\
\hline 86 & Inicialização do Round & Tela de jogo, finalização dos movimentos & $4 "$ \\
\hline 87 & Jogabilidade & Tela de jogo, desenvolvimento da partida, Round 2 & $5 "$ \\
\hline 88 & Finalização do Round & Tela de jogo, anuncio de nocaute & $2 "$ \\
\hline 89 & Finalização do Round & Tela de jogo, finalização dos movimentos & $3 "$ \\
\hline 90 & Info & Tela de Performance & $8 "$ \\
\hline 91 & Anuncio & Surgimento do Rival & $2 "$ \\
\hline 92 & Loading & TelaPreta "Loading" & $4 "$ \\
\hline 93 & Anuncio & Tela de anuncio de estágio & $2 "$ \\
\hline 94 & Anuncio & Tela de anuncio dos lutadores & $10^{\prime \prime}$ \\
\hline 95 & Animação do Jogo & Animação pré-luta Ryu, parte 1 & $1 "$ \\
\hline 96 & Animação do Jogo & Animação Ryu e Sagat, parte 2 & $5 "$ \\
\hline 97 & Animação do Jogo & Animação Ryu, parte 3 & $2 "$ \\
\hline 98 & Animação do Jogo & Animação Sagat e Ryu, parte 4 & 6" \\
\hline 99 & Inicialização do Round & Tela de jogo, preparação para combate & $2 "$ \\
\hline 100 & Jogabilidade & Tela de jogo, desenvolvimento da partida, Round 1 & $25^{\prime \prime}$ \\
\hline 101 & Finalização do Round & Tela de jogo, anuncio de nocaute & $3 "$ \\
\hline 102 & Finalização do Round & Tela de jogo, finalização dos movimentos & $8 "$ \\
\hline 103 & Inicialização do Round & Tela de jogo, preparação para combate & $2 "$ \\
\hline 104 & Jogabilidade & Tela de jogo, desenvolvimento da partida, Round 2 & $34 "$ \\
\hline 105 & Finalização do Round & Tela de jogo, anuncio de nocaute & $2 "$ \\
\hline 106 & Finalização do Round & Tela de jogo, finalização dos movimentos & $4 "$ \\
\hline 107 & Info & Tela de Performance & $9 "$ \\
\hline 108 & Loading & Tela Preta de Loading & $4 "$ \\
\hline 109 & Anúncio & Tela de anuncio de estágio & $1 "$ \\
\hline 110 & Anúncio & Tela de anuncio dos lutadores & $9 "$ \\
\hline 111 & Animação de Jogo & Animação pré-luta Cenário & $1 "$ \\
\hline 112 & Animação de Jogo & Animação pré-luta Cenário & $1 "$ \\
\hline 113 & Animação de Jogo & Animação pré-luta Ryu, Parte 1 & $1 "$ \\
\hline 114 & Animação de Jogo & Animação pré-luta Ryu, Parte 2 & $3 "$ \\
\hline 115 & Animação de Jogo & Animação pré-luta Seth, Parte 3 & 3" \\
\hline 116 & Animação de Jogo & Animação pré-luta Seth e Ryu, Parte 4 & $3 "$ \\
\hline 117 & Animação de Jogo & Animação pré-luta Seth, parte 5 & 7" \\
\hline 118 & Inicialização do Round & Tela de jogo, preparação para combate & $2 "$ \\
\hline 119 & Jogabilidade & Tela de jogo, desenvolvimento da partida, Round1 & $41 "$ \\
\hline 120 & Finalização do Round & Tela de jogo, anuncio de nocaute & $3 "$ \\
\hline 121 & Finalização do Round & Tela de jogo, finalização dos movimentos & $9 "$ \\
\hline
\end{tabular}




\begin{tabular}{|c|c|c|c|}
\hline & Tipo de Plano & Ocorrência & $\begin{array}{c}\text { Intervalo de } \\
\text { Tempo }\end{array}$ \\
\hline 122 & Inicialização do Round & Tela de jogo, preparação para combate & $4 "$ \\
\hline 123 & Jogabilidade & Tela de jogo, desenvolvimento da partida, Round 2 & $21 "$ \\
\hline 124 & Finalização do Round & Tela de jogo, anuncio de nocaute & $2 "$ \\
\hline 125 & Finalização do Round & Tela de jogo, finalização dos movimentos & 4" \\
\hline 126 & Info & Tela de Performance & $9 "$ \\
\hline 127 & Animação de Jogo & Animação & $2 "$ \\
\hline 128 & Loading & Tela Preta "Loading" & $4 "$ \\
\hline 129 & Anúncio & Tela de anuncio de estágio & $2 "$ \\
\hline 130 & Anúncio & Tela de anuncio dos lutadores & 9" \\
\hline 131 & Animação de Jogo & Animação Cenário, parte 1 & $1 "$ \\
\hline 132 & Animação de Jogo & Animação Cenário, parte 2 & $1 "$ \\
\hline 133 & Animação de Jogo & Animação Akuma & $11 "$ \\
\hline 134 & Inicialização do Round & Tela de jogo, preparação para combate & $2 "$ \\
\hline 135 & Jogabilidade & Tela de jogo, desenvolvimento da partida, Round 1 & $58 "$ \\
\hline 136 & Inicialização do Round & Tela de jogo, preparação para combate & $2 "$ \\
\hline 137 & Jogabilidade & Tela de jogo, desenvolvimento da partida, Round 2 & $1 "$ \\
\hline 138 & Finalização do Round & Tela de jogo, anuncio de nocaute & $2 "$ \\
\hline 139 & Finalização do Round & Tela de jogo, finalização dos movimentos & 6" \\
\hline 140 & Jogabilidade & Tela de jogo, desenvolvimento da partida, Round Final & $2 "$ \\
\hline 141 & Finalização do Round & Tela de jogo, anuncio de nocaute & $2 "$ \\
\hline 142 & Finalização do Round & Tela de jogo, finalização dos movimentos & $2 "$ \\
\hline 143 & Info & Tela de Performance & 9" \\
\hline 144 & Animação Narrativa & Animação final, parte 1 & 5" \\
\hline 145 & Animação Narrativa & Animação Final, parte 2 & $4 "$ \\
\hline 146 & Animação Narrativa & Animação Final, parte 3 & $8 "$ \\
\hline 147 & Animação Narrativa & Animação Final, parte 4 & $1 "$ \\
\hline 148 & Animação Narrativa & Animação Final, parte 5 & $2 "$ \\
\hline 149 & Animação Narrativa & Animação Final, parte 6 & $4 "$ \\
\hline 150 & Animação Narrativa & Animação Final, parte 7 & 6" \\
\hline
\end{tabular}

Fonte: Organizado pelo Autor

Analisando o jogo perante esta classificação em relação aos planos-sequência, do início ao fim, identificou-se um padrão semelhante ao utilizado no estudo da narrativa embutida. Devido ao ciclo constante de lutas, as questões que acontecem antes e depois, padronizam não só a recepção da informação, como também, a própria engine e os designers de modo que, com a estruturação do fluxograma das telas, basta preencher o que necessita para cada momento. Com esta decupagem, temos uma ordem concatenada de planos- 
sequência, conforme define Vanoy e Goliot-Lété (1994), tratada por unidade de ação. Neste exercício de observação, identificamos uma ordem, um padrão de repetição, o qual é quebrado:

- quando surge o rival;

- na luta com Seth, o último chefe do jogo;

- na luta extra com Akuma.

Esta observação entre telas e tempos permitiu algumas outras constatações:

- a tela de apresentação de personagens tem o cenário flamejante de fogo e o logotipo do jogo piscando para exacerbar o movimento. Esta tela é onde existe o carregamento final da luta que começa com a tela preta de loading;

- as animações de personagem e os movimentos especiais mostra-nos a integração entre 3D e 2D, colocando a narrativa e a jogabilidade como um ato contínuo;

- o tempo da luta e das outras telas intercalados tem a ver com o ápice de esforço do jogador, diferente de outras versões ou jogos, em que as lutas são em sequências e onde após uma série de batalhas existe uma exaustão nas manobras, no controle e da tensão do jogo por si só. Algumas sequências, entretanto, servem para reestabelecer a calma, e baixar o pico de euforia do jogo. No final do round, a velocidade do jogo é menor, permitindo momentaneamente sair do estado combativo e reavaliar a estratégia.

\section{2- Elementos visuais representados}

A estética predominante é um híbrido entre as linguagens cartoon e realista, em que podemos traçar um paralelo às histórias de super-heróis de editoras como Marvel e DC, pois ao mesmo tempo em que a história ocorre em um cenário tal qual um Mundo Real, existem distorções no padrão corpóreo dos personagens, como proporção dos músculos, de membros distorcidos que se esticam e até de cores como homens verdes.

Outro corolário de leis permite poderes além da realidade, expressado em proezas que desafiam a lei da gravidade e a resistência corporal de meros mortais. Cada um dos níveis de poder permite um "feedback" diferente em tela. De acordo com a diversidade e complexidade dos comandos, coisas diferentes acontecem na tela, sendo difícil descrevê-las em palavras. Tal situação cria um estado competitivo e rico em detalhes audiovisuais com seus elementos icônicos representados. O jogador domina ou não a técnica, e isto significa saber a ordem dos movimentos no direcional e o botão a ser apertado, assim como o momento exato de aplicá- 
los. Quanto mais complexo o movimento a ser executado, mais específico o "timing" a ser aplicado, bem como a oportunidade para encaixar o golpe. Isto traz recompensas que enaltecem o golpe e a dramaticidade do momento, superlativando o vencedor e o perdedor. Efeitos visuais aparecem na tela em situações extremas e nas simples, como quando um golpe é acertado. Outro aspecto associado ao resultado visual e à estética se configura em movimentos rápidos e especiais que evocam mudança na velocidade e na força do personagem, lembrando a estética sumi-ê, onde a trajetória do movimento e sua inércia potencial traça uma linha de tinta que vai se diluindo em relação à mão, ao pé, ou ao próprio corpo de quem executa a técnica.

Outro aspecto dos efeitos audiovisuais são os marcadores de tela (HUD - Head Up Display), que dinamicamente informam os dados da luta, tais como a vida do personagem, o tempo para o final do round, o poder acumulado que pode permitir liberar poder especial e round e fazem parte de um painel que não apenas resume o momento, mas dialoga com a estratégia a ser adotada quando o usuário se encontrar em um momento complicado.

3 e 4 - Escala dos Planos, incidência angular, profundidade de câmera, objetiva utilizada e - Movimentos

Como todo jogo de luta do estilo estudado, os fighting games, o ângulo de filmagem principal fica afastado dos personagens, englobando quase a totalidade do cenário, e os movimentos de câmera sempre ficam com o eixo da lente paralelo caracterizando uma tomada lateral. Porém, devido à excepcionalidade de algumas sequências de movimentos especiais, a câmera viaja sem uma direção pré-definida, subindo e descendo aleatoriamente, aproximando e afastando, mostrando o combate "por dentro" (partes do corpo batendo, sendo atingidas e a face de dor, em um breve instante), ângulos que em filme dificilmente seriam captados caso não se utilizasse tecnologias de modelagem em três dimensões como o que acontece no jogo. Na sequência de animação, a câmera encontra-se em ângulos diferenciados do combate, buscando planos faciais e corporais, mostrando o personagem em movimento.

5- Passagens de um plano para outro:

Todos os planos estão conectados entre si, formando uma narrativa única, até mesmo os que ficam carregando o cenário dão a impressão de o personagem viajar pelo mundo, para 
os locais onde vai encontrar seus adversários. Existe um padrão entre cada um desses planos e suas respectivas sequências. O encadeamento cronológico avança de acordo com as vitórias contra oponentes, representado pelo jogador que avança em uma chave de campeonato, promovendo um contexto de uma continuidade logicamente motivada.

Na questão das lutas, há a sequência inicial de animação, que ocorre como se fosse parte da luta, emendando uma frase ou posição diretamente naquele momento do combate.

\section{6- Trilha sonora}

O contexto sonoro do jogo contribui não só para a experiência do jogador, como também para o seu grau de empolgação frente aos desafios. Existem quatro níveis de camadas sonoras: a música, os elementos sonoros do cenário, o som incidental gerado pelas ações do jogador e o som que associado aos movimentos especiais e a voz dos lutadores evocam seus movimentos como kiais.

Todas estas camadas sonoras coexistem em harmonia e resulta em estímulo contínuo que se reflete na luta.

Nas sequências iniciais e finais, o som ambiente da cachoeira demarca bem o lutador em seu ambiente de origem. No começo, prepara o jogador para o que virá e no final, ajuda-o a baixar o nível de ansiedade.

Durante as lutas, uma trilha sonora específica de acordo com o cenário traz a sonoridade ao ambiente, lembrando ou não o local de sua origem.

Outro aspecto é a caracterização de cada tela mediante a sonoridade, uma vez que existem intervalos temporais e telas intermediárias do jogo, em que a trilha sonora compõe o momento e criam uma espécie de condicionamento no jogador, fazendo com que ele possa soltar o controle, alongar os dedos e relaxar, para depois voltar à competição, como se a linguagem do jogo, induzisse a esta temporalidade de ação permitindo ao jogador, alternar momentos entre a tensão e um relaxamento e assim, sua experiência possa ser o mais agradável e alongada possível.

\section{7- Relações som e imagem}

Existem dois tipos de narração: a narração feita pelo personagem nas sequências de animação inicial e final e o narrador da luta. A narrativa do personagem manifesta uma reflexão sobre o estado da luta, sendo um elemento a mais de personificação, trazendo ao 
ícone a presença de sua voz, completando o avatar em questão como um ser profundo nas várias dimensões que ele pode ser concebido, reverberando em sinergia e identidade combativa, traduzindo isso na hora do jogo, quando o personagem e o usuário são um.

Quanto ao narrador, está ele à beira da diegese, pois, embora não apareça graficamente, é representado de forma marcante por uma entonação de voz que induz a um locutor profissional de lutas.

Além da visão e da audição, o tato é o outro sentido que é explorado. Os controles são dotados de servos-motores que fazem o joystick vibrar, dando uma emoção a mais na experiência vivida. 


\section{Considerações Finais}

Os parâmetros de pesquisa referentes ao objeto apresentam uma pertinência de associação háptica ao contexto, pois na relação entre a mecânica do jogo, sua história e o contexto audiovisual, existem vetores que se entremeiam e não existe a fronteira da distinção das áreas. Dessa maneira, podemos auferir que parâmetros e protocolos são válidos para enaltecer onde existem esses embricamentos e, assim, buscar uma profundidade daquilo que está sendo analisado ou criado.

Os resultados, apesar de algumas particularidades, apresentaram grande similaridade, a natureza lúdica, narrativa e audiovisual implícita permite que haja essa sinergia entre as respostas apresentadas. Apesar da referida sinergia, sugere-se que o melhor aproveitamento dos três métodos apresentados seria mais efetivos caso compilados em uma única matriz, devido à possibilidade de ampliar a integração da informação e, consequentemente, a análise.

Algo que ficou bem acentuado foi a relação narrativa entre o aspecto mecânico e o audiovisual. A possibilidade da perícia individual que permite ser lapidada e ampliada proporcionalmente ao esforço, tempo empregado e até mesmo o gosto pelo desafio, traz entre os dois métodos citados a narrativa tanto embutida quanto emergente, como um ponto de equilíbrio entre o jogo em seu quesito mais essencial associado à questão do feedback audiovisual. Podemos sistematizar as três linhas de análise da seguinte maneira:

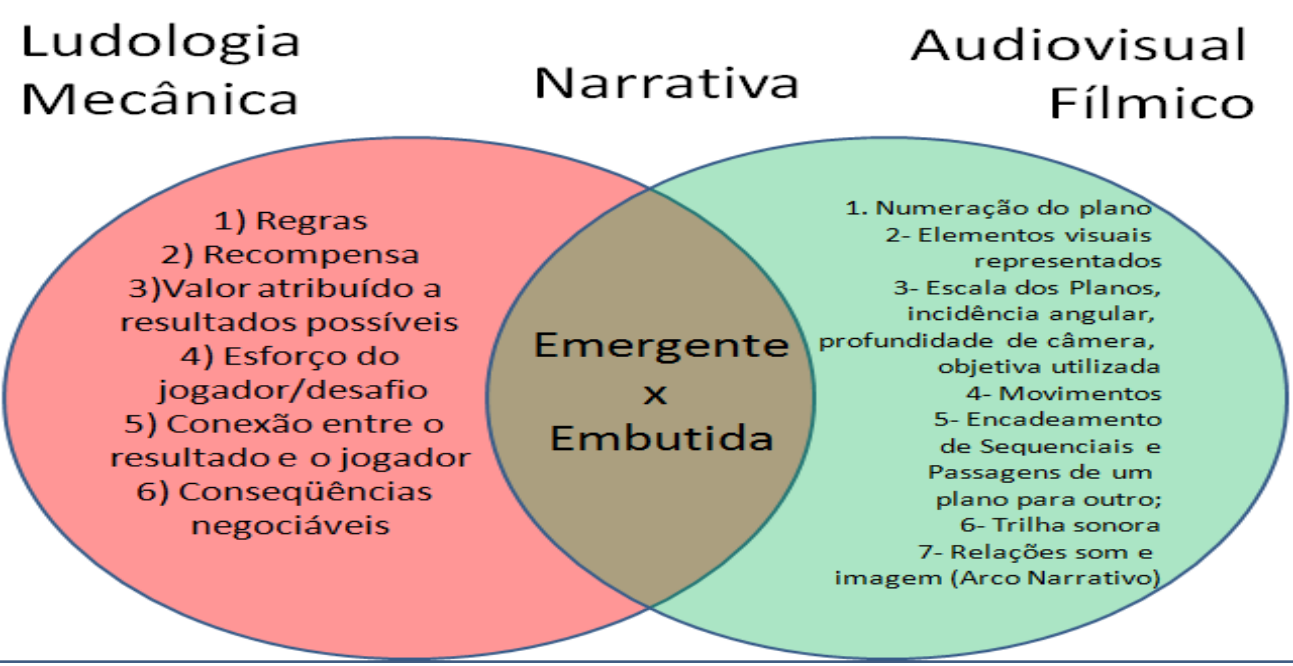

Figura 43 - Intersecção entre as três linhas de análise Fonte: Organizado pelo autor 
Temos os jogos como elementos essenciais da cultura humana, em que o fator audiovisual cria um novo ramo de jogar diante de humanidade. Muito mais que serem duas linguagens combinadas, a linguagem fílmica, da mesma forma que potencializa a narrativa expressando uma maneira diferenciada e mais detalhada de contar história, perante a diversão, segue nessa exponencialização o mesmo padrão, sendo elevada pela possibilidade de criação de símbolos e pela manipulação dos mesmos, em que o ato do jogar tem seu potencial expandido em relação à diversão e à criação. Não obstante, a tela hoje, mais que um mero emulador de sistemas imagéticos, ganha notoriedade devido à conexão com a Internet, que junta novas formas de interação e aquilo que o sistema permite. Assim, a criatividade de mentes juntas e integradas eleva mais ainda a possibilidade de novas situações no contexto lúdico audiovisual, seja para integrar novos jogadores em disputas remotas, seja para compartilhar informações, estratégias e até mesmo novos jogos.

Quanto à análise de objeto de estudo, ao examinar o jogo Super Street Fighter IV com os três métodos foi possível uma maior compreensão, principalmente dos detalhes. Minúcias estas que sempre estiverem presentes e já haviam si percebidas, porém na hora que se fez uma varredura sistêmica buscando os elementos e suas respectivas interações, tivemos clareza da integração de como é composto o mosaico que se perfaz com os elementos lúdicos, narrativos e fílmicos. Foi possível perceber como os ritmos são criados e como o jogador é induzido a uma cadeia temporal de calma e frenesi cíclico, em que camadas diversas de som se fundem de maneira uniforme com pontos em comum à imagem e a própria jogabilidade. Sem contar a questão simbólica da luta, que apesar da distância entre aquilo que ocorre no jogo e a prática, temos na versão da tela algo que se vale da dinâmica do confronto pessoal, explorando um impulso épico do jogador, criando estratégias em tempo real. O sentimento da batalha, da persistência, da marcialidade através dos símbolos que muitas vezes beiram a caricatura, cria um ambiente de esforço, onde existe o mérito para as ações em seus diversos graus, desde a satisfação de uma simples vitória, até os PERFECTS com Ultra Combos e toda mise-en-scéne criada pela hiperestimulação dos sentidos.

Os instrumentos de análise associados à ludologia e à narratologia mostraram-se concisos quanto ao jogo, porém o instrumento de análise fílmica precisou sofrer algumas compilações, e ainda não está próximo do ideal, uma vez que fora construído para uma linguagem de cinema e, necessariamente, pode não se repetir nos videogames. Fica evidente 
que existe uma série de elementos que necessitam ser aprimorados para que o contexto audiovisual do videogame possa ser analisado com um protocolo de aferição de informação perante uma linguagem específica que coadune com uma linguagem audiovisual específica dos videogames, integrada à mecânica e a narrativa.

Vemos no Hadouken, golpe do personagem que fez a trajetória na partida analisada, a síntese daquilo que fora preconizado na análise do objeto de estudo, pois:

- é um golpe presente em vários personagens, porém mesmo sendo igual é emblematicamente diferente;

- graças à sequência de comandos é disparado na tela;

- representa algo associado à mitologia oriental da projeção do ki/chi;

- sua execução está associada ao poder brilhante pela tela e ao grito;

- a mitologia do mundo do Street Fighter gira em torno do domínio desta energia. Manifestar

a técnica foi um dos motes do primeiro filme, paralelo aos jogadores que buscavam desenvolver a perícia para executar manobras, e no último filme, a energia domina o personagem a ponto de fazê-lo lutar por sua sanidade, não se deixando transformar em um demônio. Também, foi o motivo pelo qual o vilão está atrás de tal força e dos heróis que se uniram para barrá-lo;

- ao começar e terminar o jogo a imagem do Hadouken atravessando a cachoeira remetendo a continuidade da história e a importância de como a técnica está constantemente presente no jogo, como se fosse um ciclo contínuo e necessário à sua existência.

- como um mesmo elemento pode variar tanto em função da narrativa embutida, pois diversos personagens dão o golpe Hadouken, porém graças a variáveis visuais e mesmo técnicas, ganha uma enorme variabilidade em quesitos de jogabilidade, estratégia e elementos narrativos que podem ser explorados.

- existem variações na técnica ligadas diretamente à complexidade da sequência e ao timing, o jogador precisa aprimorar-se para conseguir dar tal golpe, de modo a ter uma recompensa mais expressiva.

O escopo teórico apresentado permitiu elevar a compreensão sobre os videogames, propiciando conteúdo para enquadrá-lo na matriz audiovisual. Com isso, temos uma base de análise da concepção prática voltada à produção e das relações do conteúdo audiovisual e sua interface com o ser humano em seu mais detalhado construto para uma aplicação de cunho instrucional. 
As relações cognitivas contemplam diversas variáveis em muitos níveis de interação, causando resultados orgânicos baseados em sistemas neurais que se aproximam de uma linguagem caótica em seu mais estrito senso. Tal compreensão nos permite pensar no videogame como produto ou objetivo midiático audiovisual e como um veículo voltado à cognição per se. Como seus símbolos, narrativas e mecânicas estabelecem diálogos com signos e matrizes, com veículos de outras naturezas e até mesmo conteúdos educativos é possível estabelecer relações que tenham por objetivo ensinar, alertar e conscientizar, respeitando e considerando os receptores e seus devidos "canais de entrada e saída" de informação. Isso pode ir adiante, promovendo "literacias" para despertar o interesse do público-alvo e o que necessita ser alcançado, como, por exemplo, conteúdo de fícção científica em relação a programas curriculares de Ciência.

O jogo é uma forma de emular a realidade. Baseado em símbolos e tradições, é criada uma jornada na qual existe um grau de filosofia e conhecimentos implícitos perante aquilo que se traduz de modo lúdico.

O papel que as telas cumprem neste caso, de acordo com Manovich (2001), é a releitura do olhar de um mural medieval para uma tela pintada, seja ela a tela de uma televisão, do cinema ou do celular. Um jogo como Street Fighter direciona o olhar para dentro de uma arena de gladiadores. A questão é que a representatividade de imagens nos games vai além de outras linguagens, uma vez que o estático dá lugar ao cinético e o cinético passa a permitir a interatividade. $\mathrm{O}$ fato de assumir o controle permite que o jogador pense de como seria se fosse ele vivendo aquela situação expressada no contexto do game. Fazendo uma analogia dos tempos de outrora, quando na antiguidade, um movimento de mão com o polegar para cima ou para baixo de um imperador definia a vitória ou a derrota de um lutador, hoje, os movimentos coordenados, precisos e rápidos das mãos, podem conduzi-lo a uma vitória ou a uma derrota. A tradição, ao mesmo tempo em que é utilizada para criar um universo e um pano de fundo para justificar personagens se digladiando, encontra, na virtualidade, meios de coexistir com a tecnologia e manter-se viva, adequando-se e contextualizando-se com as formas de diálogos presentes.

$\mathrm{Na}$ busca por espaços que permitam a representatividade e que estão implícitas regras de cunho cultural, surge a necessidade de aceitar o que este determinado espaço propõe e mediante a ética implícita, extrair dele novo modos de compreensão da realidade e de 
convívio. Vemos isso no Projeto Ilha Cabu (PETRY, 2010), em que analogamente à ilha temos o Dojô e as regras para um convívio de sobrevivência. Em uma ilha são necessários habilidades e conhecimentos da estrutura geográfica, uma vez que a mesma tem os seus próprios perigos representados pelas águas que a circundam e pelas armadilhas dela própria (fauna, flora, relevo e etc.). Explorá-la significa fato preponderante para a sobrevivência, assim como a vivência em um Dojô, local no qual se treina e onde é necessário muita atenção, perícia e conhecimento, pois qualquer distração ou negligência poderá terminar com um resultado desastroso. A possibilidade de trazer o espaço consagrado do Dojô para o imaginário se fez pertinente à análise até então elaborada. Trazer para o simbólico as regras de conduta desse espaço permitiu novas abordagens de análise que trouxeram novas maneiras de utilizar o código de linguagem e fazer uma relação entre "forma e conteúdo", conseguindo extrair mais questões associadas em relação ao símbolo, á metáfora e as significâncias dos objetos abordados.

Como diz o antigo ditado: "Dojô de Naki, Senjo de Warau” (cuja tradução significa "chore no treino, ria no campo de batalha"), revela que existe um lugar para se treinar e um lugar para se guerrear. A partir desta metáfora, podemos dizer que existem dois lugares na vida do usuário: um local de prática e outro para a execução daquilo que se treinou. Obviamente, vivemos em tempos e locais nos quais as guerras não existem, o que não quer dizer que não existam as jornadas individuais e coletivas. Desconsiderando os conflitos que existem em outros lugares, a guerra hoje é bem diferente daquelas que aconteciam quando esse ditado fora concebido. Assim, o Dojô também muda seu aspecto, servindo para preparar artistas marciais e não guerreiros como antigamente.

A abordagem entre filmes não ficcionais e videogames é algo que se revela enriquecedor neste momento de análise, pois, através de um eixo comum, surgem relações dialéticas, que apesar de antagônicas, tornam-se complementares. Cada uma das situações verificadas nos documentários citados são formas de se registrar o momento, de ir atrás de sentimentos manifestados, sejam de dramaticidade, ironia, sejam até mesmo firmação de uma identidade pessoal. O documentário serve como ferramenta para traçar paralelos e desmistificar sintomas que podem estar implícitos no jogo analisado ou desenvolvido. Registrando depoimentos e práticas em questões como a temporalidade metapórica ou a "razão durante" pode vir a contribuir com fatores de contribuição narrativa e fornecer bases à sensibilidade, apontar eixos específicos para onde a atenção deve ser voltada. Ao analisar a 
narrativa do jogo mediante os documentários propostos para buscarmos sinergias, encontramos uma relação de semelhança direta, que nos mostra a caricaturização dos personagens, dos cenários e eventos que são simplesmente formas de enaltecer o lado humano e evidenciar semelhanças com a vida cotidiana. Criando um vínculo que se aproxima do lado humano do personagem e do indivíduo.

A relação de interação com a informação perante o suporte audiovisual avança em duas frentes que podem parecer opostas, mas o ponto de partida de ambos os vetores caminham para encontrar-se em um ponto diametralmente oposto, no lado humano da questão. Cada vez mais existem avanços que mal dão tempo de o ser humano se acostumar, novidades capazes de deixar os filmes de ficção científica ultrapassados rapidamente. Porém, a efetividade de tais aparatos e as suas aplicações convergem para o que há de mais essencial à natureza humana. Dentro de alguns anos, novos tipos de games e de aparatos audiovisuais vão aparecer, criando sistemas que elevam a própria diversão em razões exponenciais. Além disso, a que se considerar que, os jogos sempre existirão como parte da história da humanidade onde criando uma atmosfera e uma ambiência perante o usuário, o interesse se manifeste estimulando a jogabilidade.

Para finalizar, gostaríamos de relacionar o processo que se desenrolou durante esta pesquisa e a máxima expressada por Ryu ao fim de sua lutas: "The answer lies in the heart of battle" (A resposta descansa no coração da batalha). 


\section{Referências bibliográficas}

AARSETH, E. Cybertext: Perspectives on Ergodic Literature. Baltimore: The Johns Hoplins University Press, 1997.

ARHEIM, R. Art and Visual Perception: a Psychology of the Creative Eye. Berkeley: University of California Press, 1966.

AUMONT, Jacques. Introdução. In: As Teorias dos Cineastas. Campinas: Papirus, 2004.

BATESON, G. Steps to an Ecology of Mind. Chicago: Chicago University Press, 2000.

BEINHOCKER, E. D. The Orign of Wealth. Boston: Harvard Business School Press, 2006.

BENKLER, Yochai. The Wealth of Networks. New Haven. Yale University Press, 2006.

BIN, W. Essentials of Chinese Wushu. Beijing: Foreign Lenguages Press, 1992.

BRAGA, J. L.; CALAZANS, R. Comunicação e Educação: questões delicadas na interface. São Paulo, Hacker Editores, 2001.

CAMPBELL, J. The Masks of God, Vol. 2: Oriental Mythology. New York: Penguim Books, 1976.

CHARNEY, L; SCHWARTZ, V. R. (orgs.). O cinema e a invenção da vida moderna. São Paulo: Cosac \& Naify, 2001.

CHATMAN, S. Story and Discourse: narrative structure in fiction and film. New York: Cornell University Press, 1978.

DUBIELA, R; BATTAIOLA, A. A importância das Narrativas em jogos de Computador. In: VI Simpósio Brasileiro de Jogos e Entretenimento Digital, 2007, São Leopoldo. Proceedings of SBGames, 2007.

FRASCA, G. Play the Message: Play, Game and Videogame. Rhetoric Ph. D. Dissertation IT University of Copenhagen Denmark, 2007.

GADAMER, H. G. Verdade e Método I. São Paulo: Vozes, 1997.

GALIMBERTI, U. Psiche e techne: o homem na idade da técnica. São Paulo: Paulus, 2006.

GARDNER. H. As inteligências múltiplas: a teoria na prática. Porto Alegre: Artes Médicas, 1995.

GOULD, S. Seta do tempo e ciclo do tempo: Mito e Metáfora na descoberta do tempo geológico.

São Paulo: Companhia das Letras,1991.

HILLIS, K. Sensações digitais: espaço, identidade e corporificações na realidade virtual. São Leopoldo, RS: Ed. Unisinos, 2004.

HUERGO, J. Una guía de comunicación/educación, por las diagonales de lá cultura y la política. In: APARICI, R. La Educomunicación más allá del 2.0, Madri: Editora Gedisa, 2010.

HUIZINGA, J. Homo Ludens. Perspectiva: São Paulo, 2001. 
JACOBS, M; SIHVONEN, T. In Perpetual Beta? On the Participatory Design of Facebook Games. Procedings of Digra 2011: Design of Thinking, 2011. Disponível em: <http://www.digra.org/dl/db/11312.19220.pdf>. Acesso em 2 fev 2011.

JENKINS, H. Cultura de Convergência. São Paulo: Aleph, 2008.

JUUL, J. The game, the player, the world: looking for a heart of gameness. In: Level Up: digital research conference. Proceedings. Utrechet University, 2003. Disponível em: <http://www.jesperjuul.net/text/gameplayerworld/>. Acesso em 3 ago 2010.

KLEIN, C. Martial arts and the globalization of US and Asian film industries. In: Comparative American Studies, Volume 2, Number 3. Maney Publishing: Philadelphia, 2004.

LAKATOS, E. M.; MARCONI, M. de A. Metodologia do trabalho científico:

procedimentos básicos, pesquisa bibliográfica, projeto e relatório, publicações e trabalhos científicos. São Paulo: Atlas, 1992.

LEHDONVIRTA, V; ERNKVIST, M. Knowledge Map of the virtual economy. Washington: Worldbank/Infodev, 2011. (infodev.com). Acesso em 10 maio 2012.

LEVY, P. Inteligencia Colectiva: por una antropologia del ciberspacio. Washington: Unidad de Promoción y Desarollo de la Investigación de la Organización Panamericana de la Salud., 2004.

LOURENÇO, C. E. O "Estado da Arte" da produção de teses e dissertações sobre games - entendidos como forma de comunicação - no banco de dados CAPES realizadas entre 1987 e 2012. Dissertação (Mestrado) - Escola de Comunicações e Artes, Universidade de São Paulo, São Paulo, 2012.

MANOVICH, Lev. The Language of New Media. London: MIT Press, 2001.

MARCONDES, C. Princípio da razão durante, vol. III, tomo 5, O conceito de comunicação e a epistemologia metapórica. São Paulo: Paulus, 2010.

MITCHELL, W. The Reconfigured Eye. Cambridge: MIT Press, 1982.

MORIN, E. Os sete saberes necessários à educação do futuro. Brasília: UNESCO, 2000.

NCE-USP (Núcleo de comunicação e Educação da Universidade de São Paulo) http://www.usp.br/nce. O princípio que norteia a expressão audiovisual é o estético. S.d. Disponível em: <http://www.usp.br/nce/wcp/arq/textos/77.pdf>. Acesso em 5 de jun de 2012.

PARLLET, D. The Oxford History of Board Games, Oxford: Oxford University Press, 1999.

PETRY, A. dos S. O jogo como condição da autoria e da produção de conhecimento: análise e produção em linguagem hipermídia. Tese (Tese de Doutorado). Pontifícia Universidade Católica de São Paulo, São Paulo, 2010. Disponível em: <www.ilhacabu.net/tese>. Acesso em 11 de agosto de 2012

PIAGET, J. Seis estudios de pisciología. Barcelona: Seix Barral. 1977.

POPPER, K. A lógica da pesquisa científica. São Paulo: Cultrix, 1993. 
RATIER, R. P. Comunicação: a mediação escolar, In: A Centralização da Comunicação na Socialização de Jovens, Dissertação de Mestrado, FE -USP, 2009.

RICH, E.; KINGHT, K. Artificial Intelligence. Nova York: McGraw-Hill, 1991.

SALEN, K; ZIMMERMAN, E. Rules of Play: Game Design Fundamental. Cambridge: MIT Press, 2007.

SCHWARTZ, G. Economia Política na Cibercultura e Emergência na Iconomia.

Disponível em <http://cencib.org/simposioabciber/PDFs/CC/Gilson\%20Schwartz.pdf > Acesso em 15 de agosto de 2011

VANOYE, F. GOLIOT-LÉTÉ, A. Ensaio sobre a análise fílmica. Campinas: Editora Paulus, 1994.

ZAGAL. J. P. A framework for games literacy and understanding games. 2008

Disponível em: <http://dl.acm.org/citation.cfm?id=1496991>. Acesso em 11 nov. 2011.

\section{Filmografia}

CHUBBY BOY FILMS. Balrog: behind the glory. Disponível em:

<http://www.youtube.com/watch?v=E9KvRDaIpbs>. Acesso em 23 de novembro de 2012.

CLOUD ATLAS. Direção: Tykwer, T; Wachowski, A; Wachowski, L. Warner Bros, 2012. 1 DVD (172 min).

COFINO, I. I GOT NEXT. Disponível em:

<http://www.youtube.com/watch?v=2iYPJYQTFAA>. Acesso em 10 de outubro de 2012.

COLUMBIA TRISTAR PICTURES - The Art of Action: Martial Arts in Motion Picture.

Disponível em: <http://www.youtube.com/watch?v=YvkWf-xzJY0>. Acesso em 23 de agosto de 2012.

KICK-ASS - Quebrando Tudo. Direção: Matthew Vaughn : Universal Pictures, 2010. 1 DVD (118 min).

Kozuke, S. TV SHOW. Disponível em: 〈http://www.youtube.com/watch?v=BQ9YtJC-Kd8> Acesso em 15 de julho de 2012.

NATIONAL GEOGRAPHIC, Figh science. Disponível em:

<www.youtube.com/watch?v=Q3vmzgQSxpM>. Acesso em 2 de abril de 2011.

O HOMEM COM UMA CÂMERA. Direção: Dziga Vertov: Continental, 1929. 1 DVD (68 $\min )$.

PLANETA dos Macacos. Direção: Franklin Schaffner: 20th Century Fox,1968. 1 DVD (112 $\min )$.

PLANETA dos Macacos: a Origem. Direção: Rupert Wyattt: 20th Century Fox, 2011. 1 DVD (105 min).

SHE-ha. Direção: Filmation Associates: Group W Production, 1985. (série) 
THE CURIOUS CREATIVE - THE URBANS DRAGONS TRAILLER. Disponível em: $<\mathrm{http}: / /$ www.youtube.com/watch?v=9SKIvfVfKdI\&list=UU5uHtT_VGGsOve64sA0D6qw\&i ndex $=9>$. Acesso 15 de fevereiro de 2011 .

\section{Ludografia $^{11}$}

Capcom (2010) Super Street Fighter IV. Capcom.

Namco (1980) Pac-Man. Midway.

Rovio Entertainment (2009) Angry Birds. Rovio Entertainment.

Serious Game Interactive (2006) Conflitos Globais. Serious Game Interactive.

Sonic Team (1991) Sonic the Hedghog. Sega.

Take Action Games (2009) Darfur is Dying. Rebbook Humans Right Foundation.

Toys For Bob (2011) Skylandres: Spyro’s Adventure. Actvision.

Sega (1976) Heavywheight Champ. Sega.

Technos Japan Corporation (1984) Karate Champ. Data East.

Broderbund (1984) Karateca. Broderbund.

Broderbund (1989) Prince of Persia. Broderbund.

Konami (1985) Yie-Ar Kung Fu. Konami.

Netherealm Studios (2011) Mortal Kombat 9. Warner Bros.

WWE Smack Down vs. Raw. THQ.

Namco (1994) Tekken. Namco Bandai.

Capcom (1989) Street Fighter. Capcom.

Capcom (1991) Street Fighter II. Capcom.

Capcom (1995) Street Fighter Alpha. Capcom.

Capcom (1997) Street Fighter III. Capcom.

Capcom (1995) Street Fighter Movie. Acclaim.

Capcom (1990) Street Fighter 2010. Capcom.

Arika (1996) Street Fighter EX. Capcom.

\footnotetext{
${ }^{11}$ Normas de citação de jogos de acordo com http://gamestudies.org/0902/submission_guidelines Padrão: Desenvolvedor (Ano) Nome do Jogo. Publisher. Jogos citados em ordem de aparição no texto.
} 